Supporting Information

\title{
Highly Stereoselective Synthesis of Fused Cyclopropane- $\gamma$-Lactams via Biocatalytic Iron-Catalyzed Intramolecular Cyclopropanation
}

Xinkun Ren ${ }^{+}$, Ajay L. Chandgude ${ }^{+}$, and Rudi Fasan*

Department of Chemistry, University of Rochester, 120 Trustee Road, Rochester, NY 14627, United States

+ These authors contributed equally to this work.

Correspondence should be addressed to R.F. (rfasan@ur.rochester.edu)

Table of Contents

Supplementary Tables S1-S5

Supplementary Figures S1-S5

Experimental Procedures

Compound Characterization Data

X-ray crystallographic analyses

References

NMR Spectra
Pages S2-S8

Pages S9-S25

Pages S26-S33

Pages S34-S45

Page S46-S48

Page S49

Pages S50-S83 
Table S1. Activity of hemin and hemoproteins in the intramolecular cyclopropanation of $(E)$-2diazo- $N$-(3-(4-fluorophenyl)allyl)- $N$-methylacetamide (1a). Reaction conditions: $20 \mu \mathrm{M}$ catalyst, $2.5 \mathrm{mM}$ 1a, $10 \mathrm{mM} \mathrm{Na} \mathrm{S}_{2} \mathrm{O}_{4}$, in $\mathrm{KPi}$ buffer (50 mM, pH 7), room temperature, 16 hours, in anaerobic chamber.

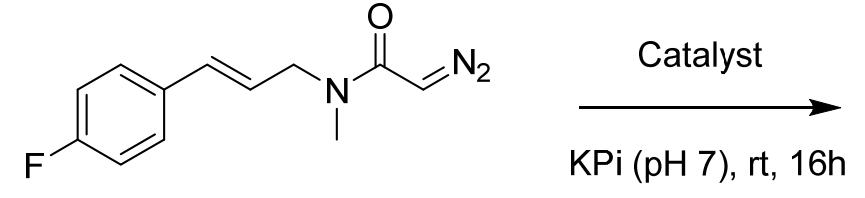

$1 a$

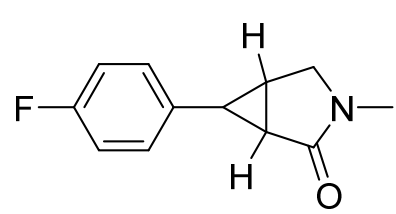

$2 a$

\begin{tabular}{|c|c|c|c|c|}
\hline Entry & Catalyst & $\begin{array}{l}\text { Yield } \\
\text { (GC) }\end{array}$ & TON & $\begin{array}{c}\% \text { ee } \\
(1 R, 5 S, 6 S)\end{array}$ \\
\hline 1 & Hemin & $17 \%$ & 21 & 0 \\
\hline 2 & $\mathrm{Mb}$ & $13 \%$ & 16 & 2 \\
\hline 3 & Catalase & $1 \%$ & 1 & 1 \\
\hline 4 & $\begin{array}{l}\text { Cytochrome } c \\
\text { (equine heart) }\end{array}$ & $1 \%$ & 1 & 4 \\
\hline 5 & $\begin{array}{c}\text { Cytochrome } c \\
\text { (Hydrogenobacter } \\
\text { thermophilus) }\end{array}$ & $0.5 \%$ & 0.6 & 9 \\
\hline 6 & Р450ВМ3 & $0.3 \%$ & 0.4 & 5 \\
\hline
\end{tabular}


Table S2. Activity and selectivity of viable $\mathrm{Mb}$ variants from the $\mathrm{Mb}(\mathrm{H} 64 \mathrm{~V})$-based mutability landscape library in the intramolecular cyclopropanation of (E)-2-diazo- $N$-(3-(4fluorophenyl)allyl)- $N$-methylacetamide (1a). Reaction conditions: $1 \mathrm{mM} \mathrm{1a}, \mathrm{Mb}$-expressing $E$. coli cells $(\mathrm{C} 41(\mathrm{DE} 3))$ at the cell density $\left(\mathrm{OD}_{600}=40\right)$, in KPi buffer $(50 \mathrm{mM}, \mathrm{pH} 7)$, room temperature, 16 hours, in anaerobic chamber.

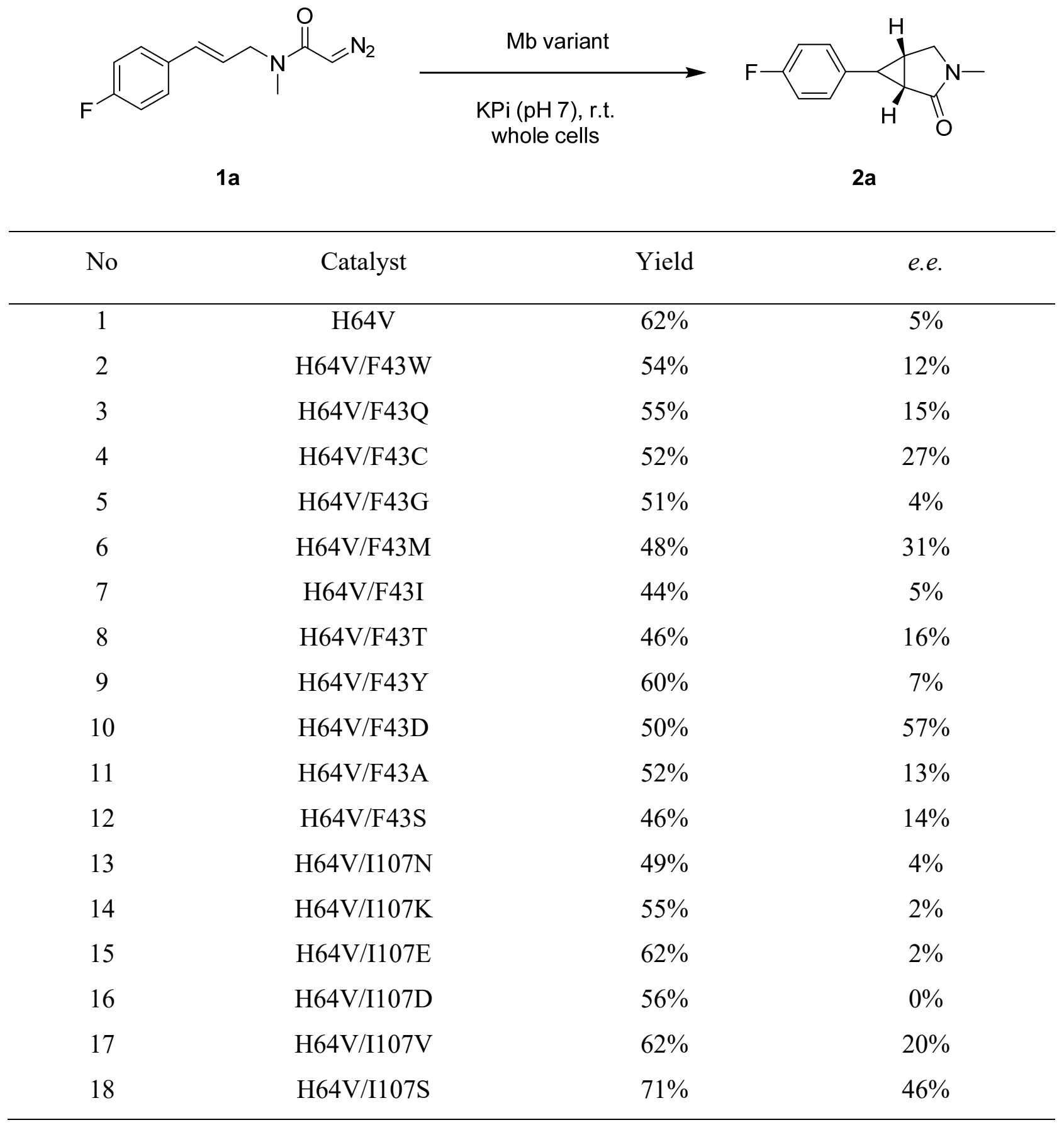




\begin{tabular}{|c|c|c|c|}
\hline 19 & $\mathrm{H} 64 \mathrm{~V} / \mathrm{I} 107 \mathrm{H}$ & $52 \%$ & $0 \%$ \\
\hline 20 & H64V/I107Y & $46 \%$ & $6 \%$ \\
\hline 21 & H64V/I107W & $55 \%$ & $4 \%$ \\
\hline 22 & H64V/I107T & $59 \%$ & $27 \%$ \\
\hline 23 & H64V/I107P & $69 \%$ & $71 \%$ \\
\hline 24 & H64V/I107L & $52 \%$ & $4 \%$ \\
\hline 25 & $\mathrm{H} 64 \mathrm{~V} / \mathrm{V} 68 \mathrm{~F}$ & $68 \%$ & $9 \%$ \\
\hline 26 & H64V/V68D & $47 \%$ & $7 \%$ \\
\hline 27 & $\mathrm{H} 64 \mathrm{~V} / \mathrm{V} 68 \mathrm{~T}$ & $30 \%$ & $28 \%$ \\
\hline 28 & H64V/V68S & $72 \%$ & $79 \%$ \\
\hline 29 & H64V/V68W & $59 \%$ & $7 \%$ \\
\hline 30 & H64V/V68E & $54 \%$ & $8 \%$ \\
\hline 31 & $\mathrm{H} 64 \mathrm{~V} / \mathrm{V} 68 \mathrm{~N}$ & $64 \%$ & $42 \%$ \\
\hline 32 & H64V/V68R & $43 \%$ & $7 \%$ \\
\hline 33 & H64V/V68C & $64 \%$ & $32 \%$ \\
\hline 34 & H64V/V68G & $61 \%$ & $80 \%$ \\
\hline 35 & H64V/V68A & $80 \%$ & $80 \%$ \\
\hline 36 & H64V/L29P & $50 \%$ & $6 \%$ \\
\hline 37 & H64V/L29M & $52 \%$ & $5 \%$ \\
\hline 38 & H64V/L29S & $58 \%$ & $55 \%$ \\
\hline 39 & H64V/L29A & $73 \%$ & $48 \%$ \\
\hline 40 & H64V/L29Y & $65 \%$ & $48 \%$ \\
\hline 41 & H64V/L29F & $57 \%$ & $9 \%$ \\
\hline 42 & $\mathrm{H} 64 \mathrm{~V} / \mathrm{L} 29 \mathrm{~N}$ & $55 \%$ & $4 \%$ \\
\hline 43 & H64V/L29H & $52 \%$ & $3 \%$ \\
\hline 44 & H64V/L29T & $80 \%$ & $47 \%$ \\
\hline 45 & H64V/L29G & $80 \%$ & $41 \%$ \\
\hline 46 & H64V/L29Q & $46 \%$ & $10 \%$ \\
\hline 47 & H64V/L29C & $63 \%$ & $33 \%$ \\
\hline
\end{tabular}


Table S3. Activity and selectivity of representative $\mathrm{Mb}$ variants from the third and fourth rounds of catalyst evolution via site-saturation mutagenesis (Figure 2). Reaction conditions: $2.5 \mathrm{mM} 1 \mathrm{a}$, $20 \mu \mathrm{M}$ purified protein in $0.5 \mathrm{~mL} \mathrm{KPi}$ buffer $(50 \mathrm{mM}, \mathrm{pH}$ 7), room temperature, 16 hours in anaerobic chamber.<smiles>CN(C/C=C/c1ccc(F)cc1)C(=O)C=[W]</smiles>

$1 a$

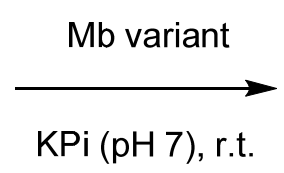

$\mathrm{KPi}(\mathrm{pH} 7)$, r.t.

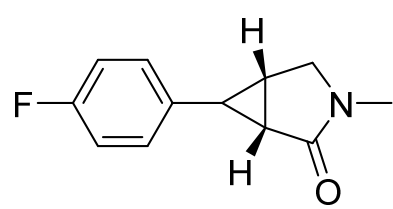

2a

\begin{tabular}{cccc}
\hline Catalyst & $\begin{array}{c}\text { Yield } \\
(\mathbf{G C})\end{array}$ & TON & $\begin{array}{c}\text { e.e. } \\
(\mathbf{1 R , 5 S}, \mathbf{6 S})\end{array}$ \\
\hline $\mathrm{WT}$ & $13 \%$ & 16 & $2 \%$ \\
$\mathrm{H} 64 \mathrm{~V}$ & $22 \%$ & 28 & $5 \%$ \\
$\mathrm{H} 64 \mathrm{~V} / \mathrm{V} 68 \mathrm{~A}$ & $59 \%$ & 74 & $82 \%$ \\
$\mathrm{H} 64 \mathrm{~V} / \mathrm{V} 68 \mathrm{G}$ & $57 \%$ & 72 & $81 \%$ \\
$\mathrm{~F} 43 \mathrm{~L} / \mathrm{H} 64 \mathrm{~V} / \mathrm{V} 68 \mathrm{~A}$ & $73 \%$ & 91 & $91 \%$ \\
$\mathrm{~F} 43 \mathrm{R} / \mathrm{H} 64 \mathrm{~V} / \mathrm{V} 68 \mathrm{~A}$ & $75 \%$ & 94 & $91 \%$ \\
$\mathrm{~F} 43 \mathrm{Y} / \mathrm{H} 64 \mathrm{~V} / \mathrm{V} 68 \mathrm{~A}$ & $91 \%$ & 114 & $92 \%$ \\
$\mathrm{~F} 43 \mathrm{M} / \mathrm{H} 64 \mathrm{~V} / \mathrm{V} 68 \mathrm{~A}$ & $80 \%$ & 100 & $92 \%$ \\
$\mathrm{~F} 43 \mathrm{H} / \mathrm{H} 64 \mathrm{~V} / \mathrm{V} 68 \mathrm{~A} / \mathrm{I} 107 \mathrm{~L}$ & $99 \%$ & 124 & $98 \%$ \\
$\mathrm{~F} 43 \mathrm{H} / \mathrm{H} 64 \mathrm{~V} / \mathrm{V} 68 \mathrm{~A} / \mathrm{I} 107 \mathrm{~T}$ & $93 \%$ & 116 & $99 \%$ \\
$\mathrm{~F} 43 \mathrm{Y} / \mathrm{H} 64 \mathrm{~V} / \mathrm{V} 68 \mathrm{~A} / \mathrm{I107V}$ & $>99 \%$ & 125 & $99 \%$ \\
\hline
\end{tabular}


Table S4. Optimization studies for $\mathrm{Mb}(\mathrm{F} 43 \mathrm{Y}, \mathrm{H} 64 \mathrm{~V}, \mathrm{~V} 68 \mathrm{~A}, \mathrm{I107V})$-catalyzed intramolecular cyclopropanation of 1a using purified protein and Mb-expressing E. coli cells (C41(DE3)). Reaction conditions: 1-10 mM 1a, $20 \mu \mathrm{M}$ purified protein or Mb-expressing E. coli cells (C41(DE3)) at the indicated cell density $\left(\mathrm{OD}_{600}\right)$ in $0.5 \mathrm{~mL}$ KPi buffer $(50 \mathrm{mM}, \mathrm{pH} 7)$, room temperature, 16 hours in anaerobic chamber. $\mathrm{Mb}$-free cells produce a background conversion of $\sim 10 \%$ ( $0 \%$ ee) likely due to free hemin in the cell.<smiles>CN(C/C=C/c1ccc(F)cc1)C(=O)C=[W]</smiles>

$1 \mathrm{a}$

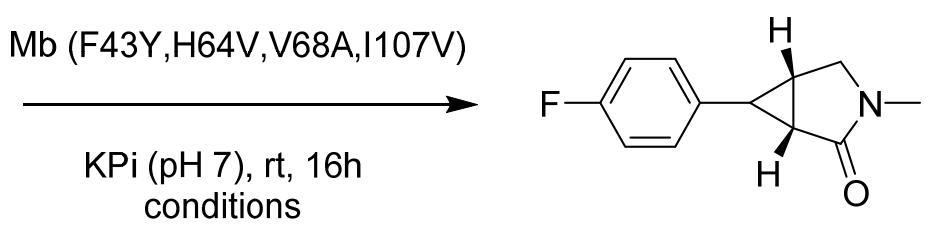

2a

\begin{tabular}{llccccc}
\hline No & Catalyst & $\begin{array}{c}\text { Protein/cell } \\
\text { conc. }\end{array}$ & $\begin{array}{c}{[\mathbf{1 a}]} \\
(\mathbf{m M})\end{array}$ & $\begin{array}{c}\text { Yield } \\
(\mathbf{G C})\end{array}$ & TON & $\begin{array}{c}\text { e.e. } \\
(\mathbf{1} \boldsymbol{R}, \mathbf{5 S}, \mathbf{6} \boldsymbol{S})\end{array}$ \\
\hline 1 & Purified protein & $20 \mu \mathrm{M}$ & 1 & $>99 \%$ & 50 & $99 \%$ \\
2 & Purified protein & $20 \mu \mathrm{M}$ & 2.5 & $>99 \%$ & 125 & $99 \%$ \\
3 & Purified protein & $20 \mu \mathrm{M}$ & 5 & $94 \%$ & 236 & $98 \%$ \\
4 & Purified protein & $20 \mu \mathrm{M}$ & 10 & $88 \%$ & 439 & $91 \%$ \\
5 & Whole cells & OD $=20$ & 1 & $>99 \%$ & 97 & $98 \%$ \\
6 & Whole cells & OD $=20$ & 2.5 & $>99 \%$ & 242 & $98 \%$ \\
7 & Whole cells & OD $=20$ & 5 & $91 \%$ & 441 & $97 \%$ \\
8 & Whole cells & OD $=20$ & 10 & $78 \%$ & 755 & $88 \%$ \\
9 & Whole cells & OD $=40$ & 1 & $>99 \%$ & 48 & $>99 \%$ \\
10 & Whole cells & OD $=40$ & 2.5 & $>99 \%$ & 121 & $>99 \%$ \\
11 & Whole cells & OD $=40$ & 5 & $>99 \%$ & 242 & $>99 \%$ \\
12 & Whole cells & OD $=40$ & 10 & $93 \%$ & 450 & $94 \%$ \\
\hline
\end{tabular}




\begin{tabular}{|c|c|c|c|c|c|c|}
\hline 13 & Whole cells & $\mathrm{OD}=60$ & 1 & $>99 \%$ & 32 & $>99 \%$ \\
\hline 14 & Whole cells & $\mathrm{OD}=60$ & 2.5 & $>99 \%$ & 81 & $>99 \%$ \\
\hline 15 & Whole cells & $\mathrm{OD}=60$ & 5 & $>99 \%$ & 162 & $>99 \%$ \\
\hline 16 & Whole cells & $\mathrm{OD}=60$ & 10 & $94 \%$ & 322 & $95 \%$ \\
\hline
\end{tabular}


Table S5. $\mathrm{Mb}(\mathrm{F} 43 \mathrm{Y}, \mathrm{H} 64 \mathrm{~V}, \mathrm{~V} 68 \mathrm{~A}, \mathrm{I107V})$-catalyzed cyclization of allyl $\alpha$-diazoacetamides containing unactivated olefinic groups. Reaction conditions: $5 \mathrm{mM}$ allyl $\alpha$-diazoacetamide, $\mathrm{Mb}$ (F43Y,H64V,V68A,I107V)-expressing E. coli $\left(\mathrm{OD}_{600}=40\right)$ in KPi buffer $(50 \mathrm{mM}, \mathrm{pH}$ 7), 40 mL-scale, r.t., $16 \mathrm{~h}$.
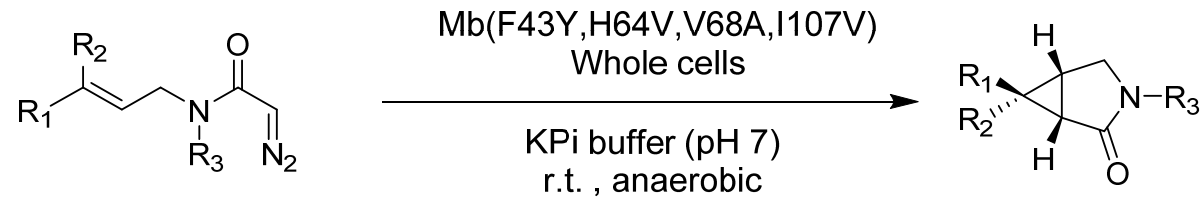

\begin{tabular}{|c|c|c|c|}
\hline Entry & Product & Yield (GC) & e.e. \\
\hline 1 & $2 \mathrm{~g}$ & $51 \%$ & $90 \%$ \\
\hline 2 & $2 \mathrm{~h}$ & $99 \%$ & $28 \%$ \\
\hline 3 & $2 i$ & $23 \%$ & $67 \%$ \\
\hline 4 & ${ }_{2 j}$ & $53 \%$ & $65 \%$ \\
\hline
\end{tabular}


Figure S1. Crystal structure of sperm whale myoglobin $(\mathrm{Mb})$. The amino acid residues lining the distal heme pocket are highlighted as stick models in light blue. The heme group (yellow) and the heme-coordinating proximal histidine (green) are shown as stick models.

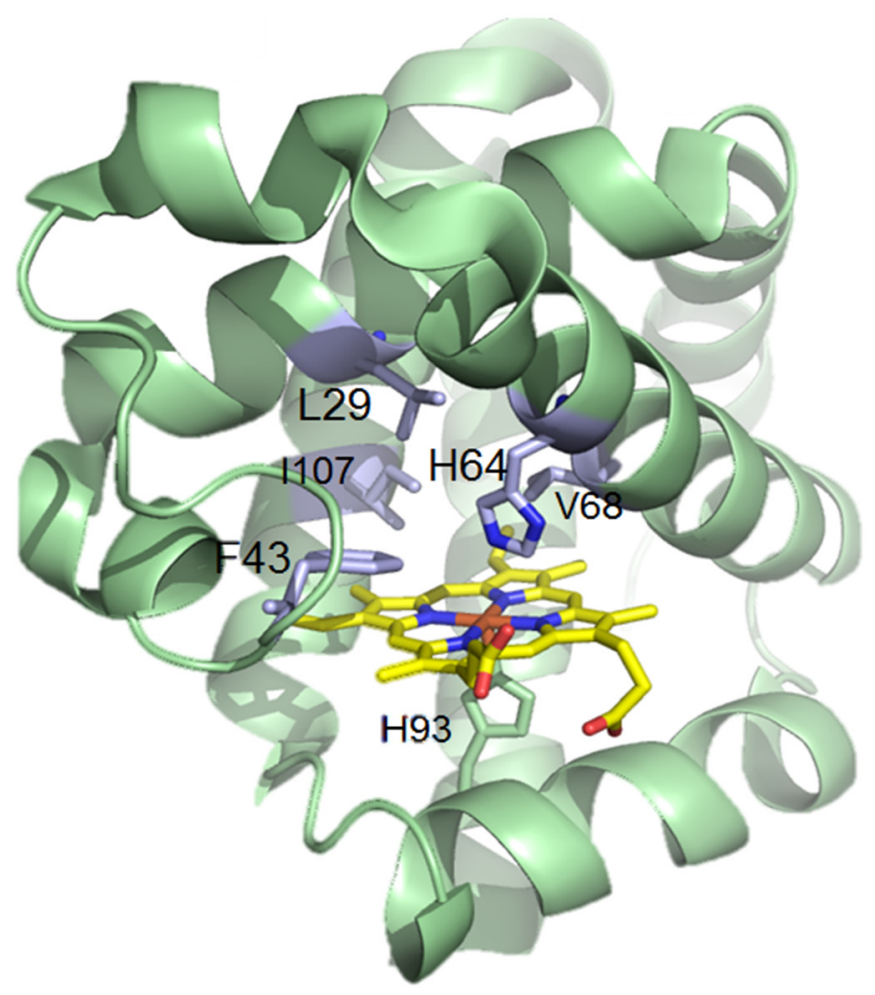


Figure S2 Time-course analysis of $\mathrm{Mb}(\mathrm{F} 43 \mathrm{Y}, \mathrm{H} 64 \mathrm{~V}, \mathrm{~V} 68 \mathrm{~A}, \mathrm{I107V})$-catalyzed intramolecular cyclopropanation of (E)-2-diazo- $N$-(3-(4-fluorophenyl)allyl)- $N$-methylacetamide $\quad$ (1a) Conversion was determined by gas chromatography using calibration curves with isolated 2a. Reaction conditions: $\mathrm{Mb}(\mathrm{F} 43 \mathrm{Y}, \mathrm{H} 64 \mathrm{~V}, \mathrm{~V} 68 \mathrm{~A}, \mathrm{I1} 07 \mathrm{~V})$ expressing C41(DE3) E. coli cells at $\mathrm{OD}_{600}$ $=40,5 \mathrm{mM} 1 \mathrm{a}$ in oxygen-free potassium phosphate buffer $(50 \mathrm{mM}, \mathrm{pH}$ 7.0). The experiments were performed in duplicates.

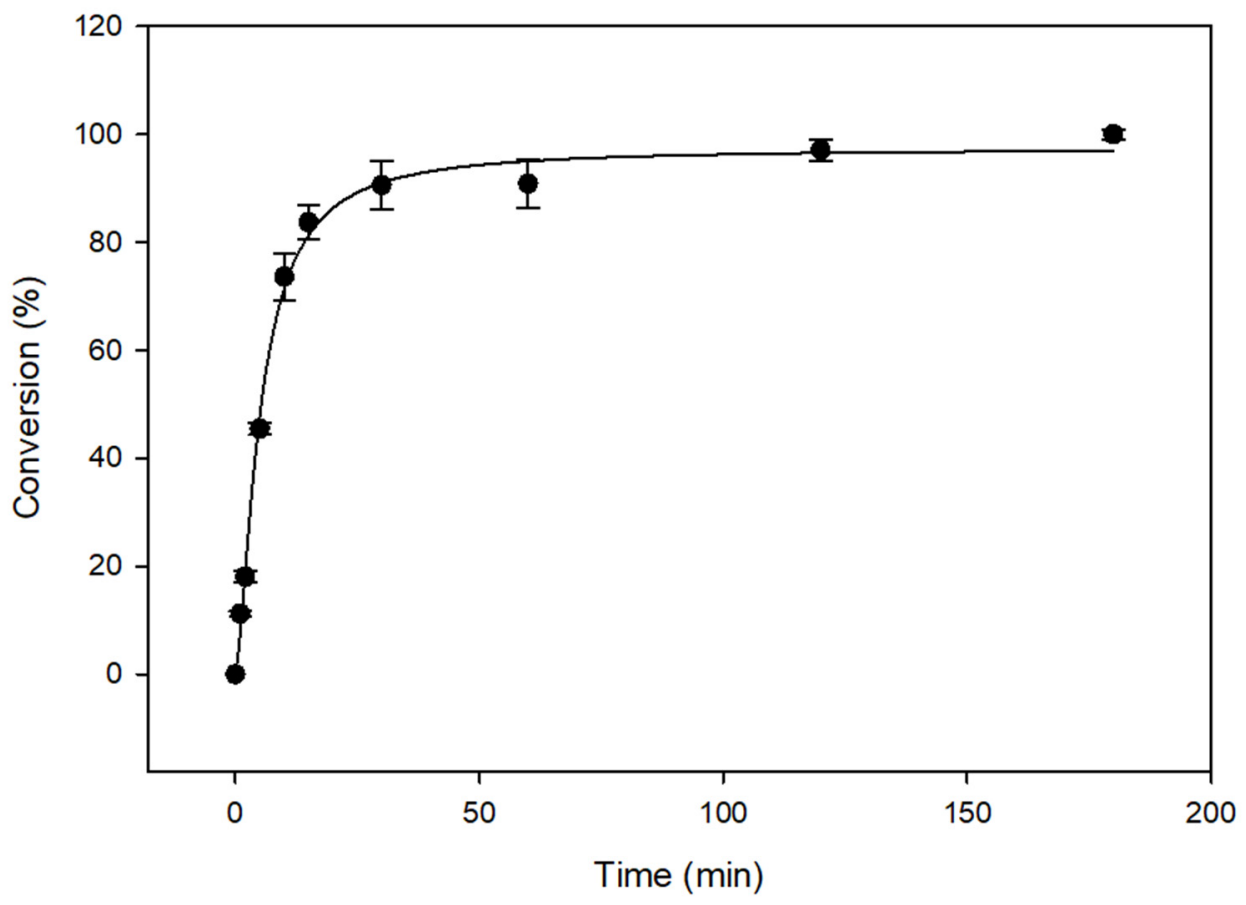


Figure S3. GC and SFC analysis for the determination of an enantiomeric excess in the Mbcatalyzed intramolecular cyclopropanation reactions. The reference racemic samples were prepared as described in the experimental procedures.

$>\quad$ Chiral GC analysis of racemic 2a (top) and enzymatically produced $\mathbf{2 a}$ product by $\mathrm{Mb}$ (F43Y,H64V,V68A,I107V) variant (bottom):
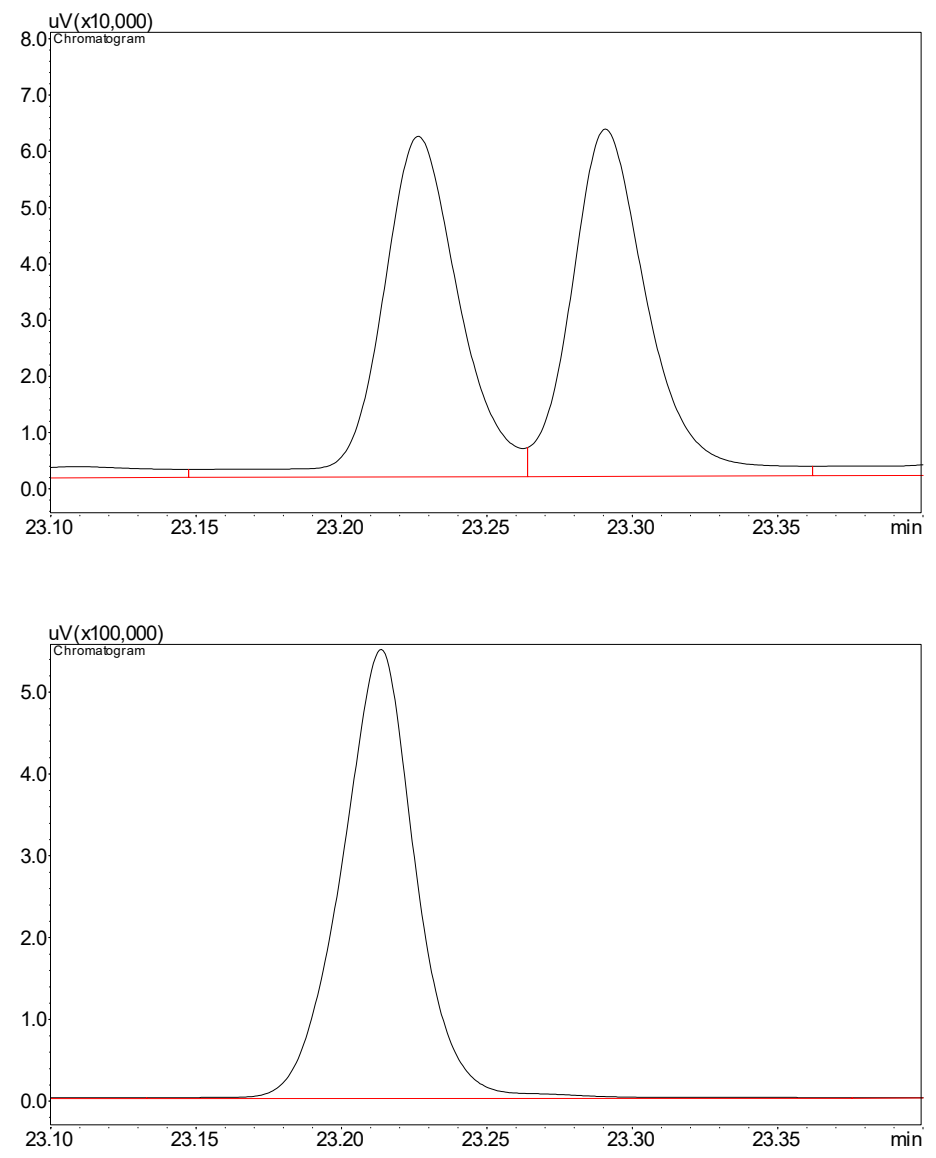
Chiral GC analysis of racemic $\mathbf{2 b}(t o p)$ and enzymatically produced $\mathbf{2} \mathbf{b}$ product by $\mathrm{Mb}$ (F43Y,H64V,V68A,I107V) variant (bottom):
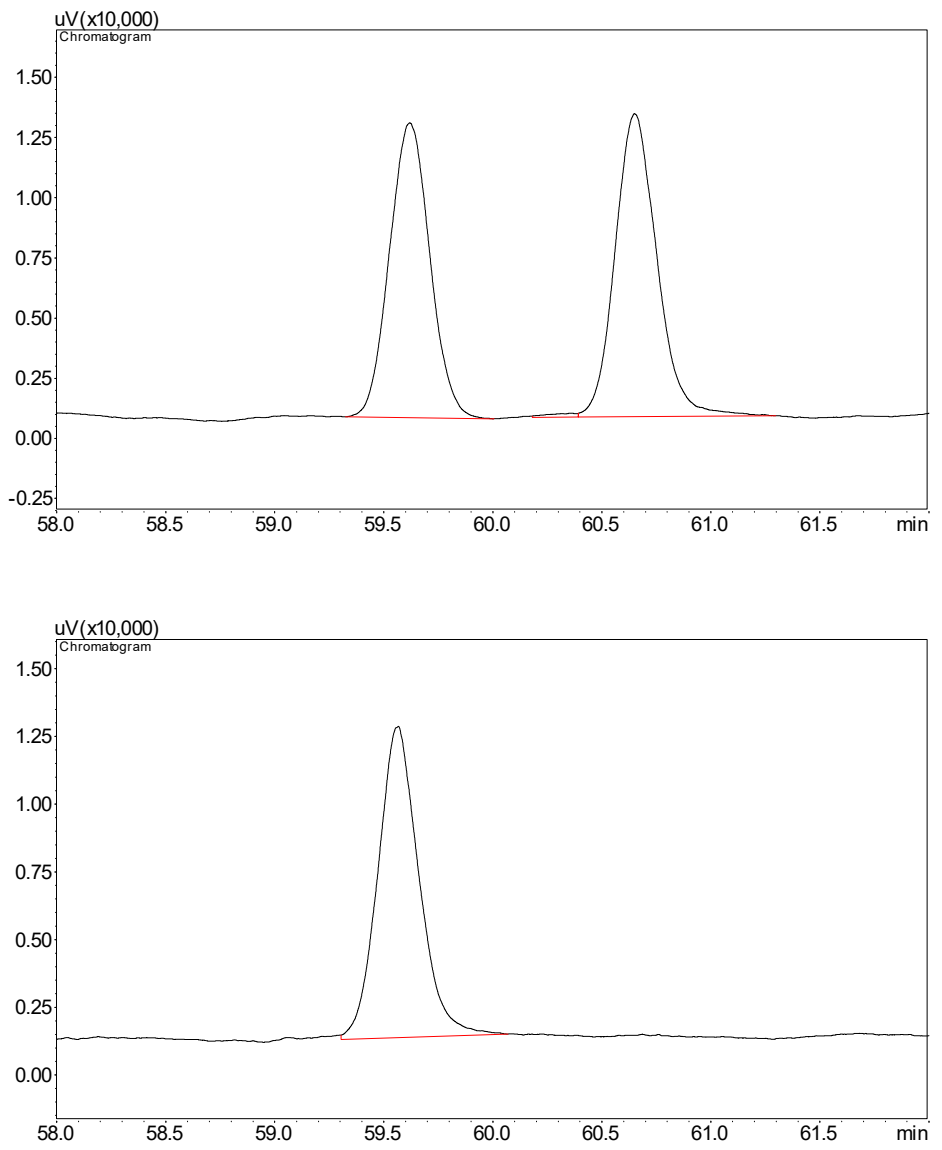
Chiral GC analysis of racemic $2 \mathbf{c}(t o p)$ and enzymatically produced $2 \mathbf{c}$ product by $\mathrm{Mb}$ (F43Y,H64V,V68A,I107V) variant (bottom):
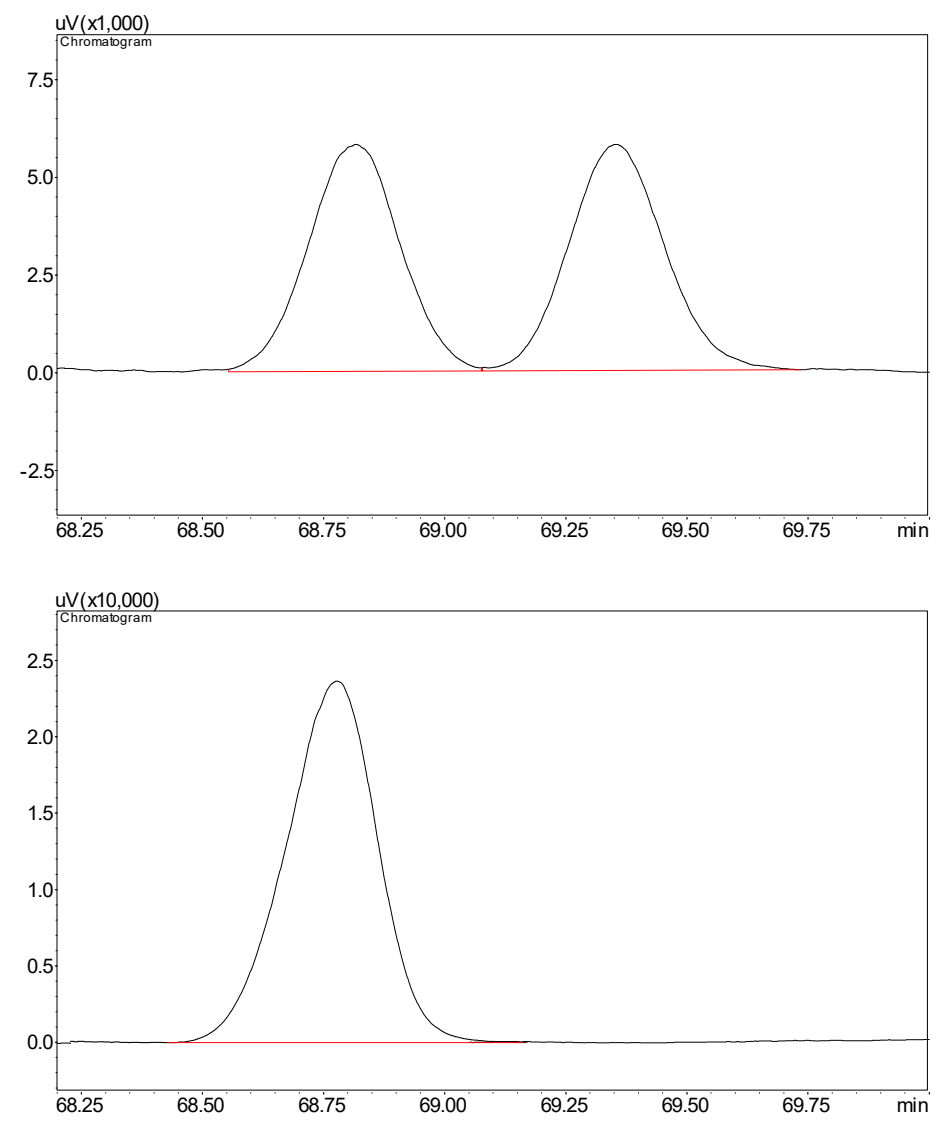
$>\quad$ Chiral SFC analysis of racemic $\mathbf{2 d}(t o p)$ and enzymatically produced $\mathbf{2 d}$ product by $\mathrm{Mb}$ (F43Y,H64V,V68A,I107V) variant (bottom):
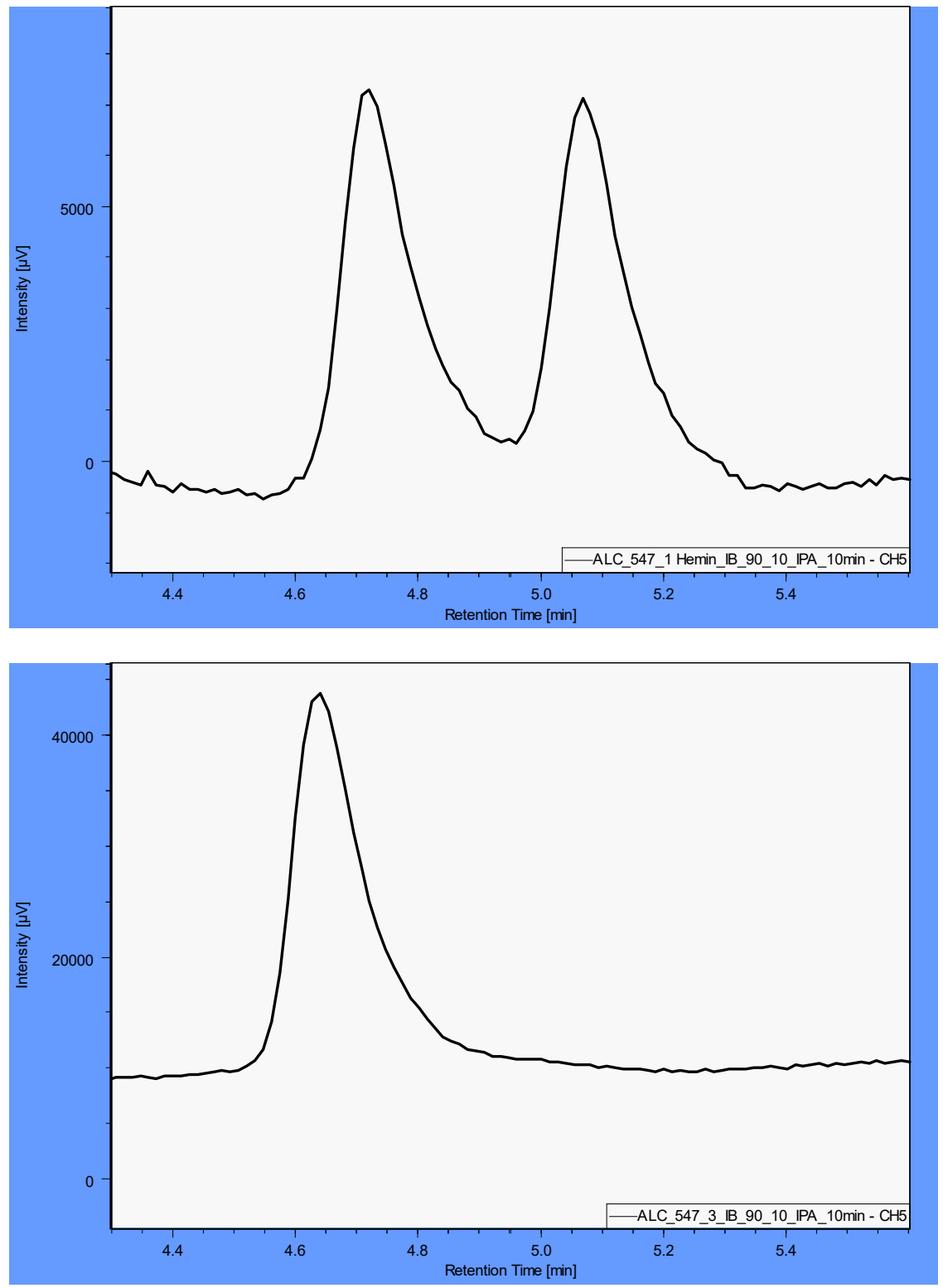
$>\quad$ Chiral GC analysis of racemic (Mb-H64V catalyzed whole-cell reaction) 2e (top) and enzymatically produced $2 \mathrm{e}$ product by $\mathrm{Mb}(\mathrm{F} 43 \mathrm{Y}, \mathrm{H} 64 \mathrm{~V}, \mathrm{~V} 68 \mathrm{~A}, \mathrm{I107V})$ variant (bottom):
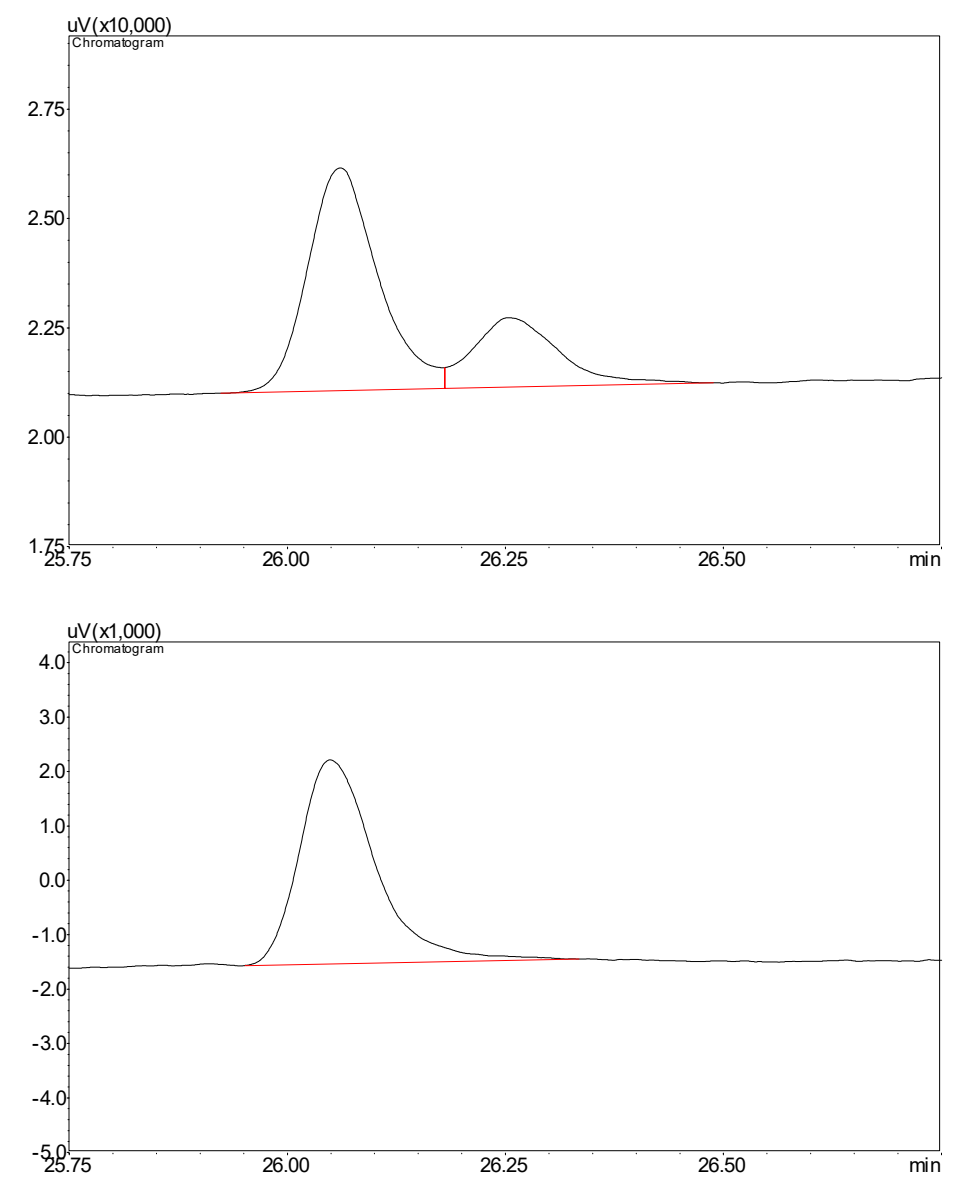
Chiral GC analysis of racemic $2 \mathbf{f}(t o p)$ and enzymatically produced $2 \mathbf{f}$ product by $\mathrm{Mb}$ (F43Y,H64V,V68A,I107V) variant (bottom):
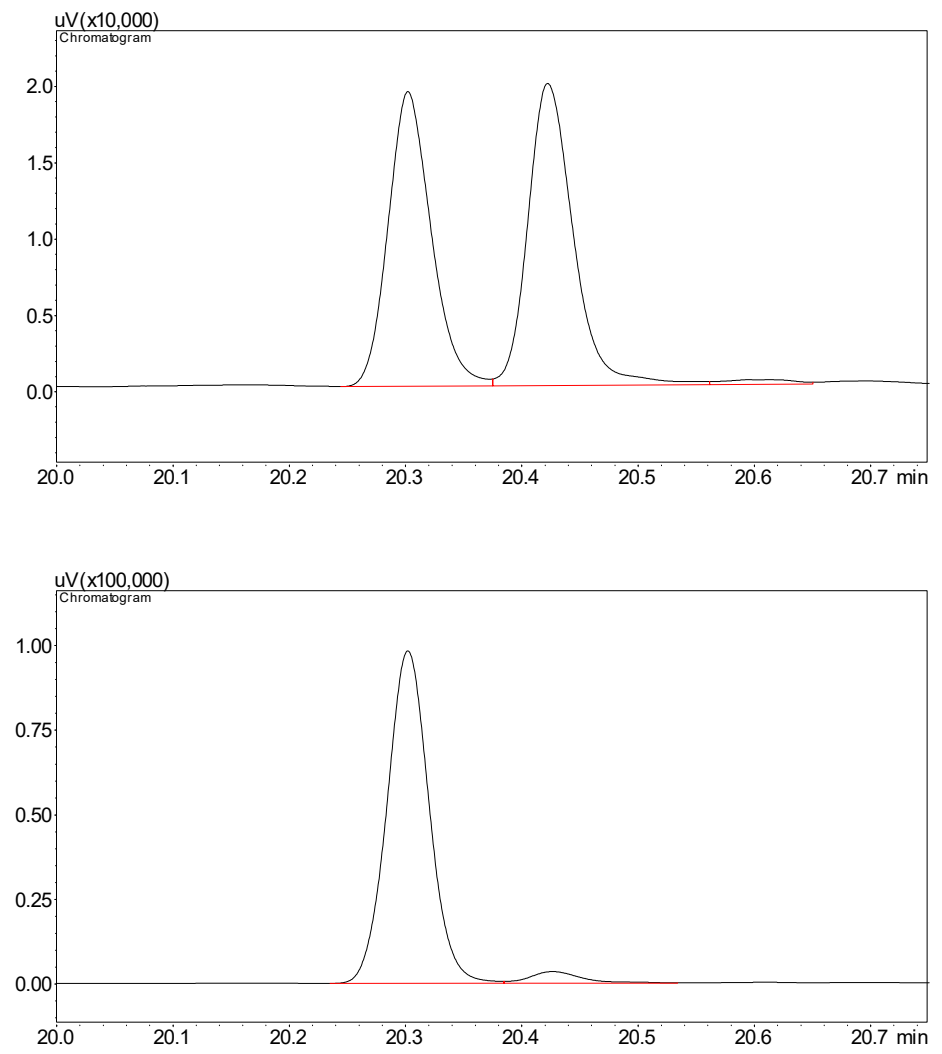
$>\quad$ Chiral GC analysis of racemic $2 \mathbf{g}(t o p)$ and enzymatically produced $\mathbf{2 g}$ product by $\mathrm{Mb}$ (F43Y,H64V,V68A,I107V) variant (bottom):
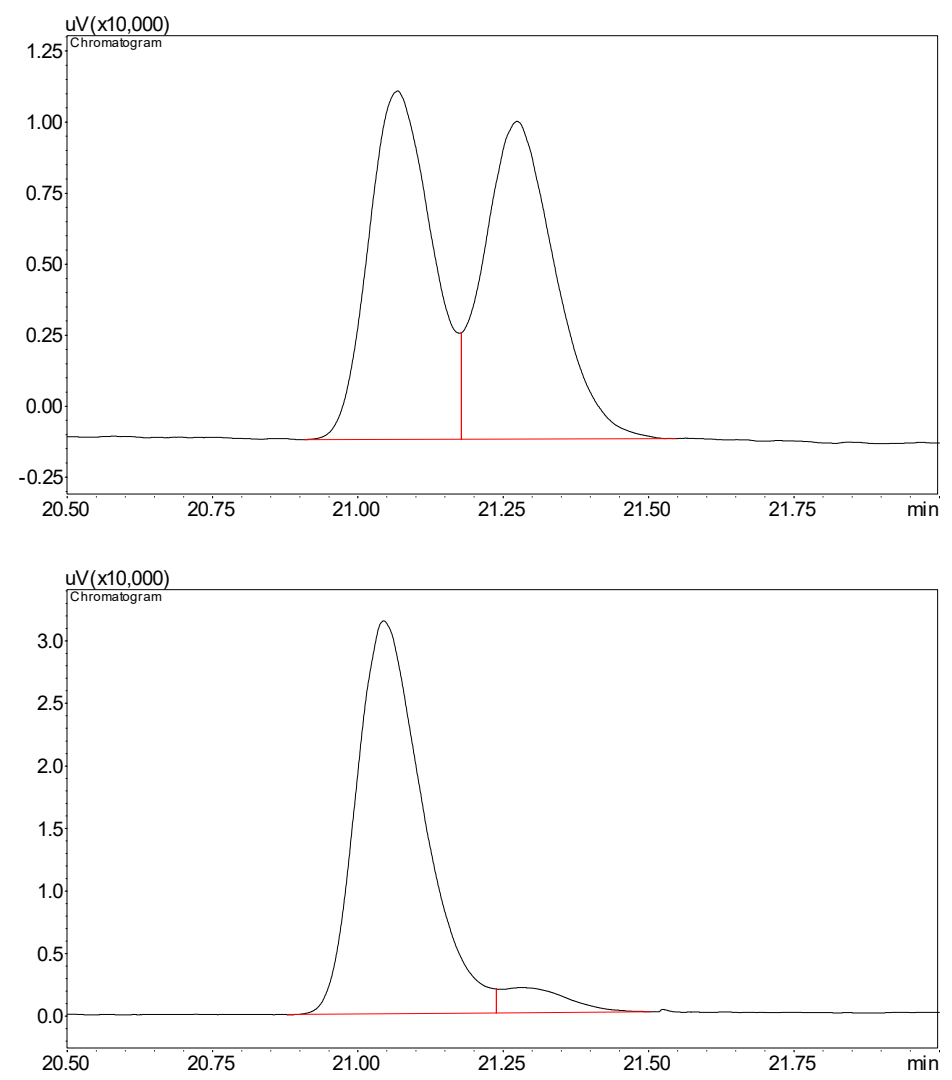
$>\quad$ Chiral GC analysis of racemic $\mathbf{2 h}(t o p)$ and enzymatically produced $\mathbf{2 h}$ product by $\mathrm{Mb}$ (H64V,V68G) variant (bottom):
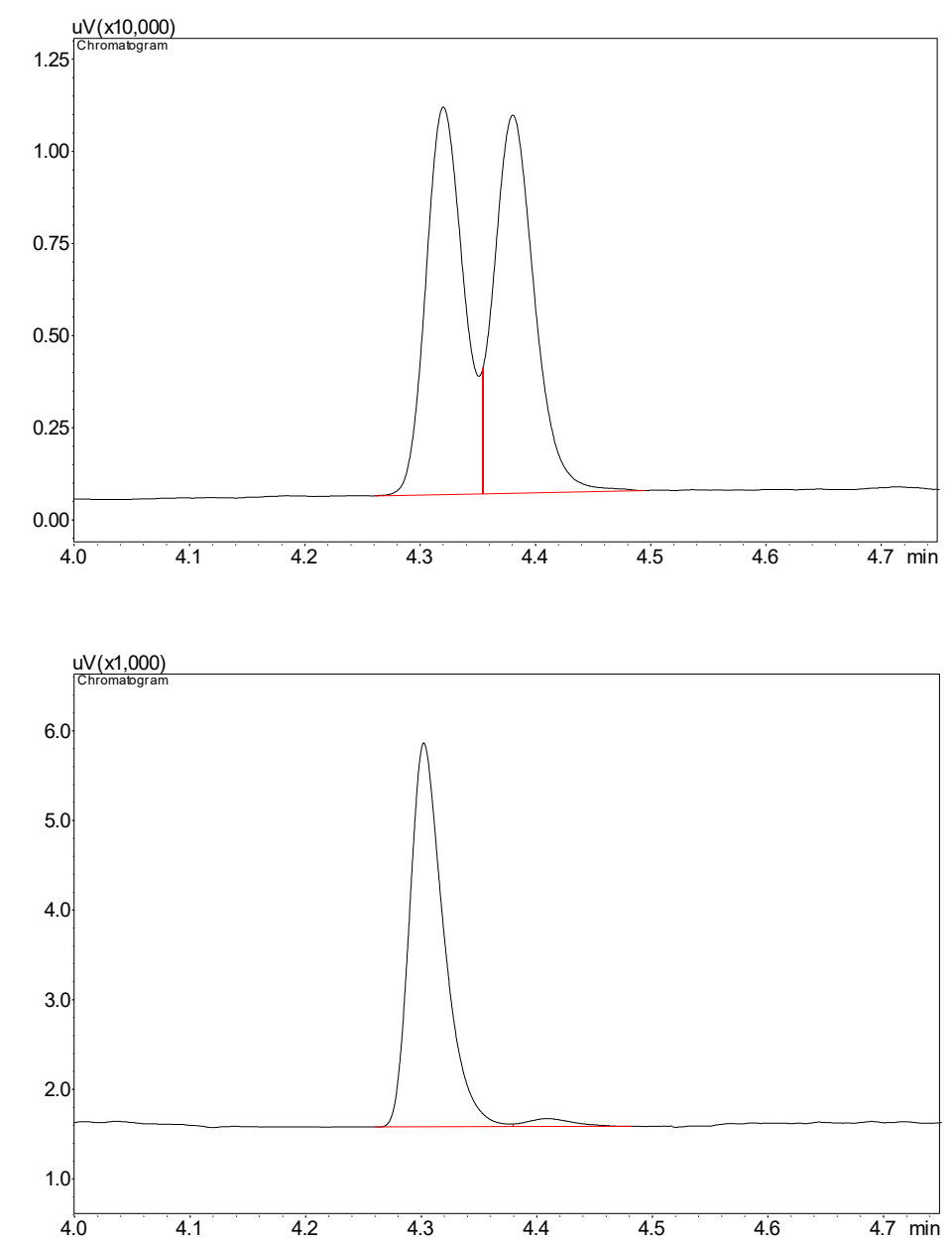
Chiral GC analysis of racemic $2 \mathbf{i}(t o p)$ and enzymatically produced $2 \mathbf{i}$ product by $\mathrm{Mb}$ (H64V,V68G) variant (bottom):
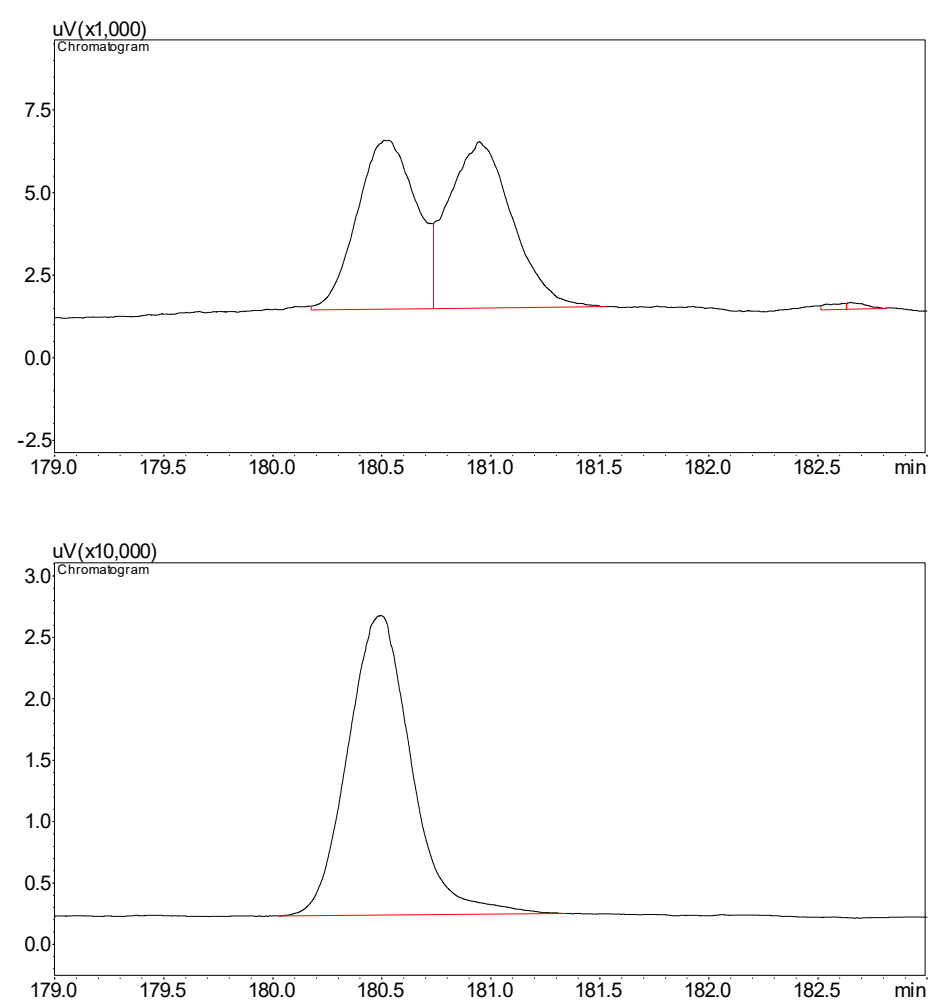
$>\quad$ Chiral GC analysis of racemic $2 \mathbf{j}(t o p)$ and enzymatically produced $\mathbf{2} \mathbf{j}$ product by $\mathrm{Mb}$ (H64V,V68G) variant (bottom):
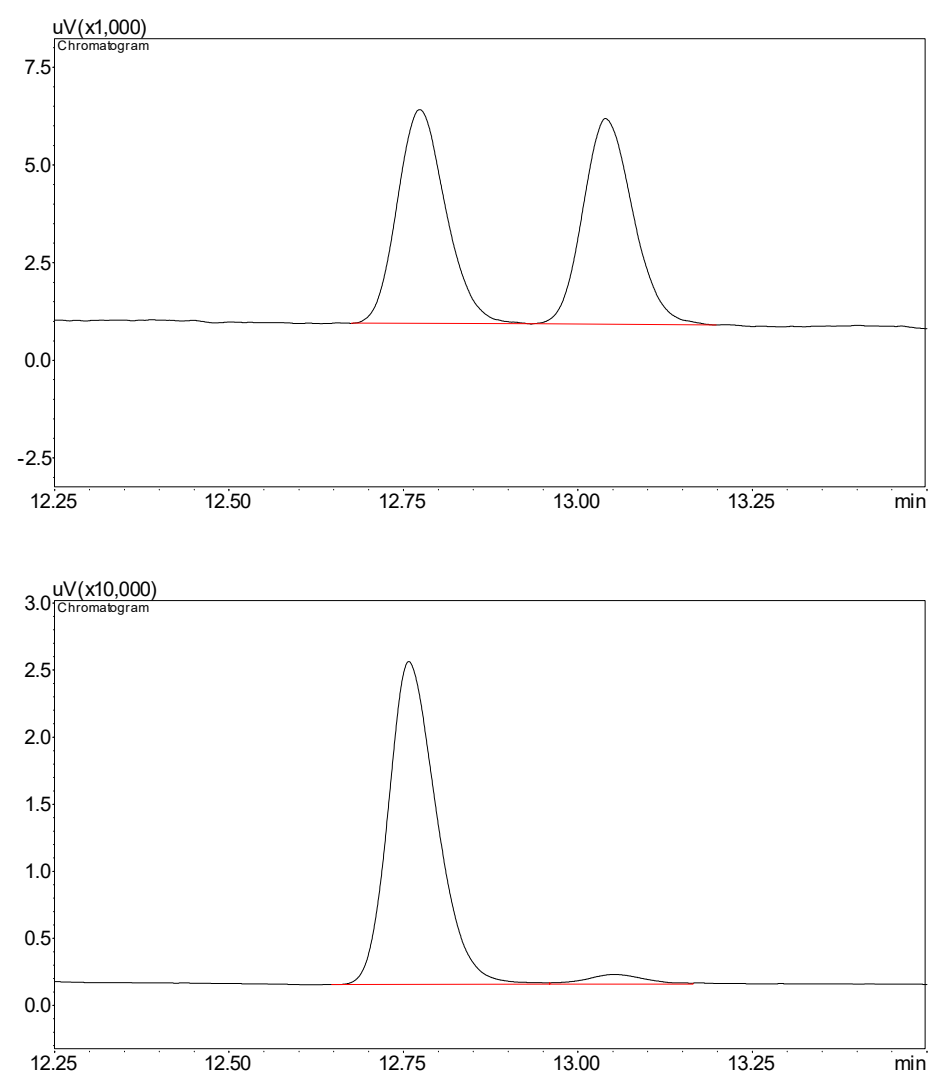
$>\quad$ Chiral GC analysis of racemic $\mathbf{2 k}(t o p)$ and enzymatically produced $\mathbf{2 k}$ product by $\mathrm{Mb}$ (F43Y,H64V,V68A,I107V) variant (bottom):
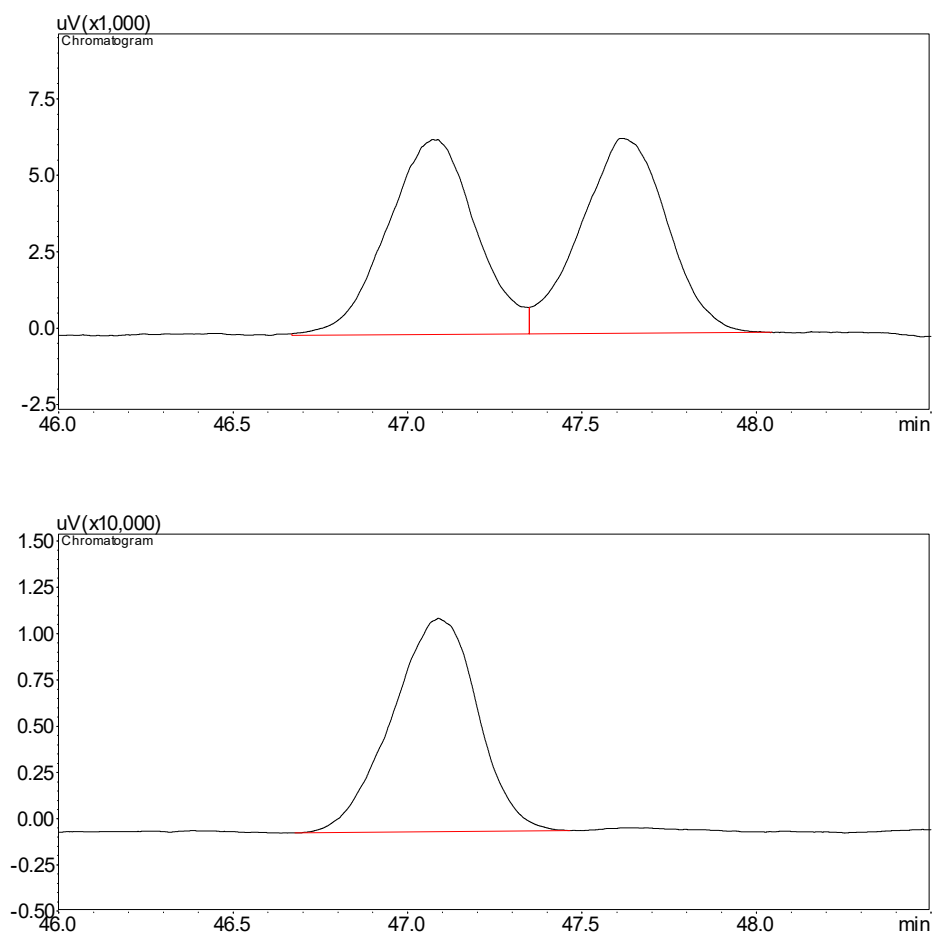
Chiral GC analysis of racemic $\mathbf{2 l}$ (top), enzymatically produced $\mathbf{2 l}$ product by $\mathrm{Mb}$ (F43Y,H64V,V68A,I107V) variant (bottom):
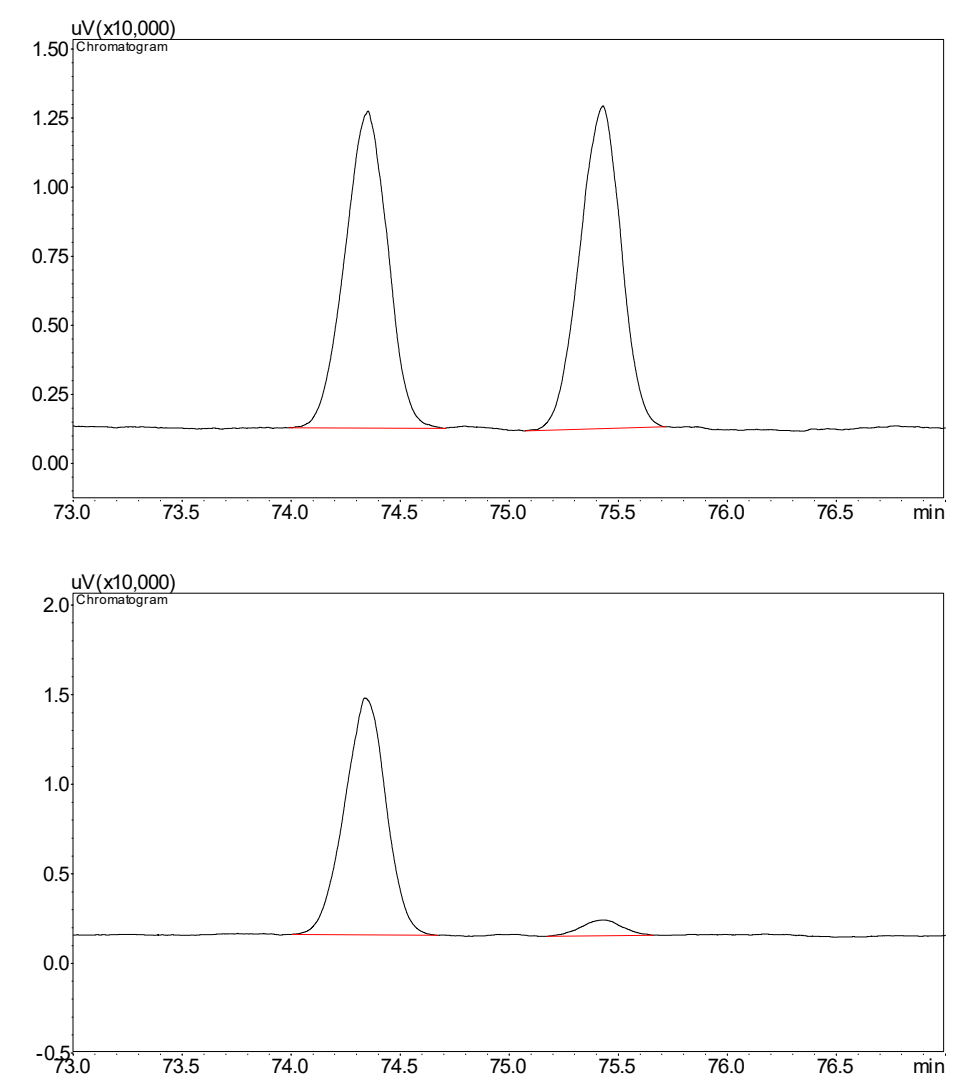
$>\quad$ Chiral SFC analysis of racemic $\mathbf{2 m}$ (top), enzymatically produced $\mathbf{2 m}$ product by $\mathrm{Mb}$ (F43Y,H64V,V68A,I107V) variant (bottom):
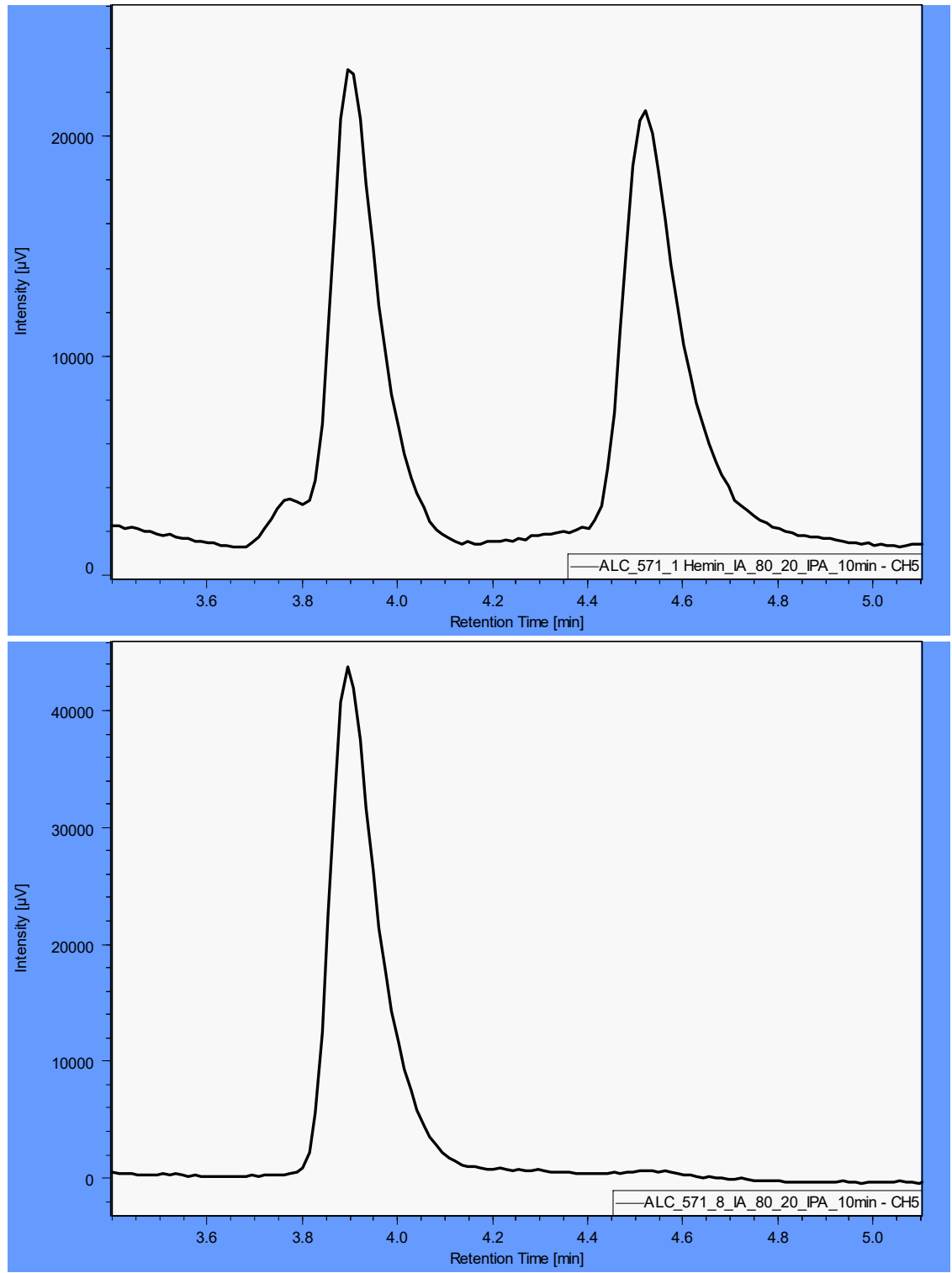
$>\quad$ Chiral SFC analysis of racemic 2n (top), enzymatically produced $\mathbf{2 n}$ product by $\mathrm{Mb}$ (F43Y,H64V,V68A,I107V) variant (bottom):

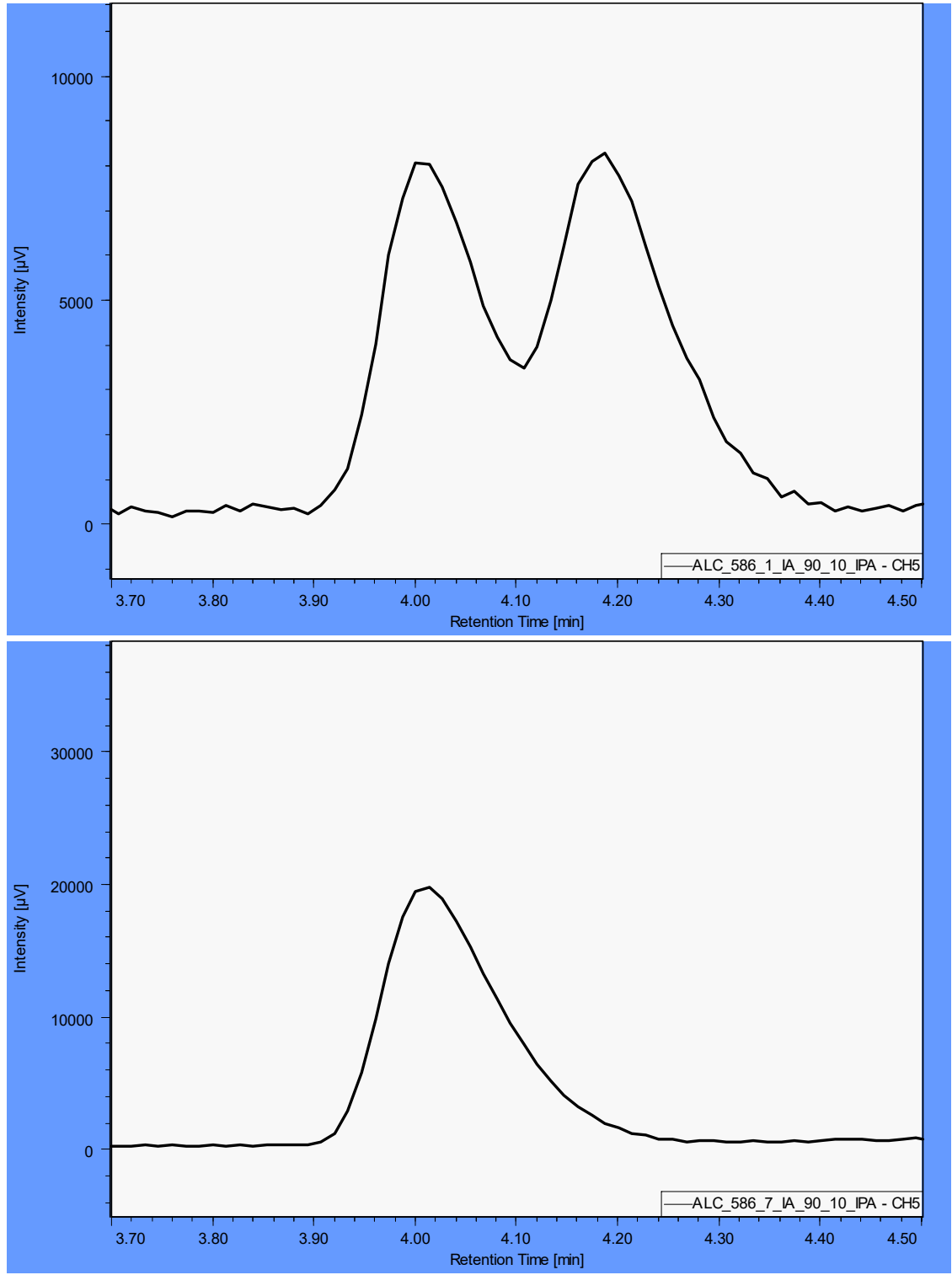


Figure S4. Anisotropic displacement ellipsoid plot of (1R,5S,6S)-3-methyl-6-phenyl-3azabicyclo[3.1.0]hexan-2-one (2b) with ellipsoids drawn at the 50\% probability level. Hydrogen atoms are represented here as spheres of arbitrary radius.

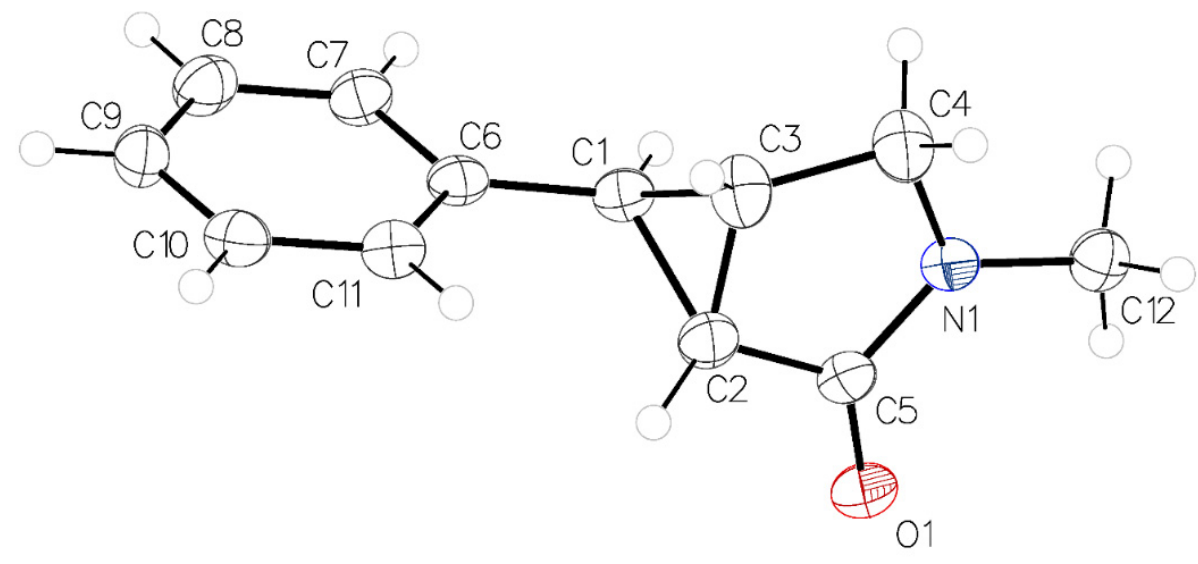

Figure S5. Anisotropic displacement ellipsoid plot of (1R,5S,6S)-6-(4-chlorophenyl)-3methoxy-3-azabicyclo[3.1.0]hexan-2-one $\mathbf{2 k}$ ) with ellipsoids drawn at the 50\% probability level. Hydrogen atoms are represented here as spheres of arbitrary radius.

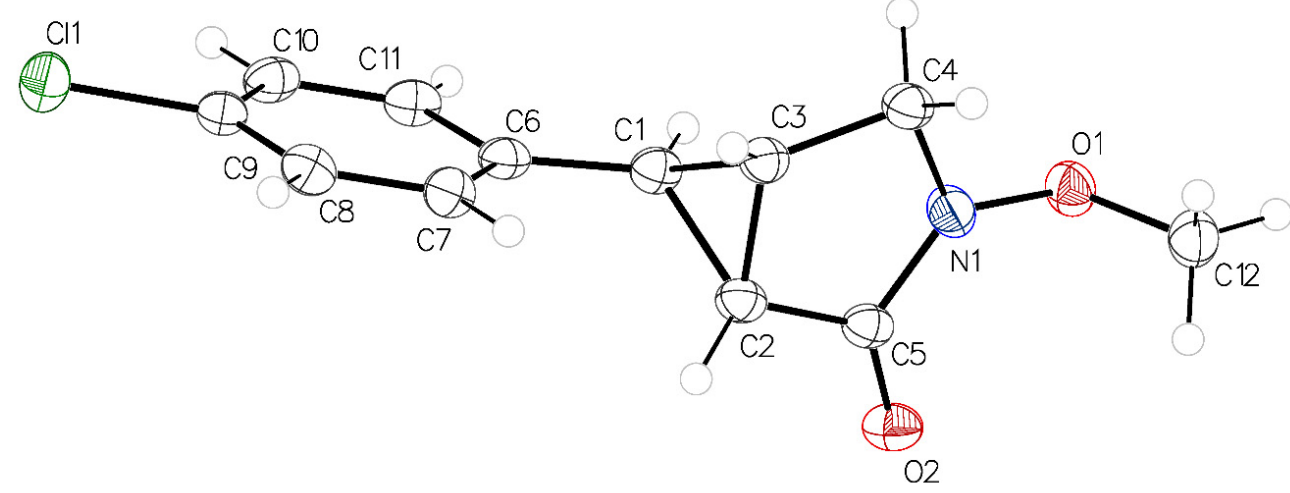




\section{Experimental Procedures}

\section{General Information}

All chemicals and reagents were purchased from commercial suppliers (Sigma-Aldrich, AK Scientific, Alfa Aesar, TCI, Acros) and used without any further purification, unless otherwise stated. ${ }^{1} \mathrm{H}$, and ${ }^{13} \mathrm{C}$ NMR spectra were measured on a Bruker DPX-500 instrument (operating at $500 \mathrm{MHz}$ for ${ }^{1} \mathrm{H}$ and $125 \mathrm{MHz}$ for ${ }^{13} \mathrm{C}$ ). Tetramethylsilane (TMS) served as the internal standard $(0 \mathrm{ppm})$ for ${ }^{1} \mathrm{H} \mathrm{NMR}$ and $\mathrm{CDCl}_{3}$ was used as the internal standard (77.0 ppm) for ${ }^{13} \mathrm{C}$ NMR. Flash column chromatography purification was carried out using AMD Silica Gel $60 \AA$ 230-400 mesh or Alumina, (Fisher adsorption) 80-200 mesh. Thin Layer Chromatography (TLC) was carried out using Merck Millipore TLC silica gel 60 F254 glass plates.

\section{Protein Expression}

Cloning procedures of the $\mathrm{Mb}$ variants investigated in this work were described previously., ${ }^{1,2}$ The oligonucleotides used for site saturation mutagenesis are shown in Table S6. The $\mathrm{Mb}$ variants were expressed in E. coli BL21(DE3) or C41(DE3) cells as follows. After transformation, cells were grown in TB medium (ampicillin, $\left.100 \mathrm{mg} \mathrm{L}^{-1}\right)$ at $37{ }^{\circ} \mathrm{C}(200 \mathrm{rpm})$ until OD600 reached 0.6. Cells were then induced with $0.25 \mathrm{mM}$ isopropyl- $\beta$-D-1thiogalactopyranoside (IPTG) and $0.3 \mathrm{mM} \delta$-aminolevulinic acid (ALA). After induction, cultures were shaken at $180 \mathrm{rpm}$ and $27^{\circ} \mathrm{C}$ and harvested after $20 \mathrm{~h}$ by centrifugation at 4,000 rpm at $4{ }^{\circ} \mathrm{C}$. Myoglobin concentration was determined after cell lysis by sonication, followed by CO-binding assay using an extinction coefficient $\varepsilon_{424}=187 \mathrm{mM}^{-1} \mathrm{~cm}^{-1}$.5,6 
Table S6. Oligonucleotide used for site saturation mutagenesis

\begin{tabular}{ll} 
Oligonucleotide & \multicolumn{1}{c}{ sequence $\left(\mathbf{5} \mathbf{- 3}^{\prime} \mathbf{)}\right.$} \\
\hline XhoI Rev & GGCTTTGTTAGCAGCCGGAT \\
L29NNK Fwd & GTCACGGTCAGGACATCNNKATCCGTCTGTTC \\
F43NNK Fwd & CAC CCG GAAACCCTG GAAAAANNKGACCGTTTC \\
H64NNK Fwd & GAAGGCTTCTGAAGACCTGAAAAAANNKGGTGTTACCG \\
V68NNK Fwd & CCTGAAAAAACACGGTGTTACCNNKCTGACCGCT \\
I107NNK Fwd & CCCGATCAAATACCTGGAGTTCNNKTCTGAAGCTATC \\
\hline
\end{tabular}




\section{Synthetic Procedures:}

\section{Synthesis of trans-allylic diazo acetamides:}

All diazo-compounds were synthesized by following reported procedures. ${ }^{3,4}$ The allylic alcohols were synthesized according to a published procedure ${ }^{3}$ and then used for the synthesis of diazo acetamides.

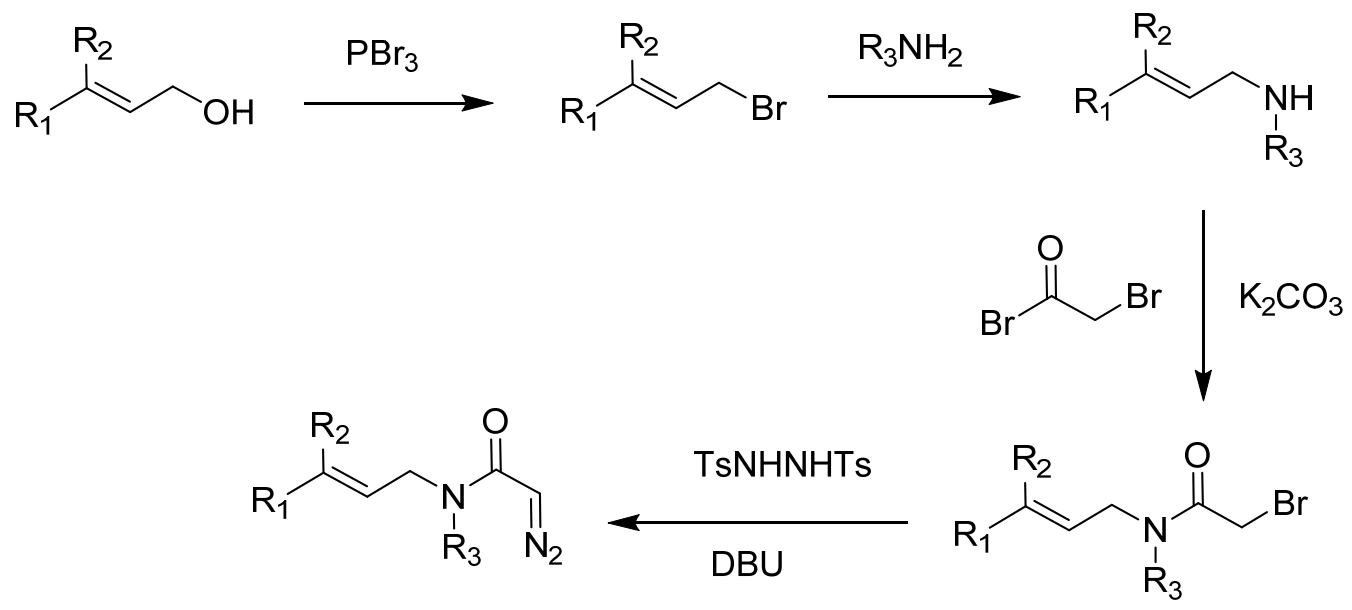

\section{General Procedure A: Synthesis of trans-allylic bromide from trans-allylic alcohol:}

A solution of trans-allylic alcohol (1.0 equiv.) in DCM was added $\mathrm{PBr}_{3}(0.5$ equiv.) at $0{ }^{\circ} \mathrm{C}$. The reaction mixture was stirred at room temperature for $2 \mathrm{~h}$, subsequently quenched by the addition of saturated aqueous $\mathrm{NaHCO}_{3}$ solution and diluted with DCM. The aqueous phase was separated and extracted with DCM. The combined organic layers were washed with brine, dried over $\mathrm{MgSO}_{4}$ and concentrated in vacuo and obtained product was used in the next step without any further purification.

General Procedure B: Synthesis of trans-allylic amines from trans-allylic bromide by using methyl amine:

To a solution of methyl amine in EtOH (3 eq), trans-allylic bromide ( $3 \mathrm{mmol}$ in $2 \mathrm{~mL}$ EtOH) was added slowly over 10 minutes at $0{ }^{\circ} \mathrm{C}$ and stirred at room temperature until the reaction was completed (6-12 h). After the evaporation of the solvent, residue was washed with 
in diethyl ether $(4 \mathrm{X})$. Crude product was dissolved in water $(20 \mathrm{~mL})$ and made basic by using 1 $\mathrm{M} \mathrm{NaOH}$. The reaction mixture was extracted with diethyl ether (3X). The organic phase was dried over $\mathrm{MgSO}_{4}$. The solvent was removed in vacuo and the obtained product was used in the next step without any future purification.

\section{General Procedure C: Synthesis of trans-allylic amines from trans-allylic bromide by using amine:}

To a solution of amine $(1.1 \mathrm{eq})$ in $10 \mathrm{~mL} \mathrm{EtOH}$, trans-allylic bromide $(3 \mathrm{mmol})$ was added slowly at $0{ }^{\circ} \mathrm{C}$ and stirred at room temperature until the reaction was completed (6-12 h). After the evaporation of the solvent, residue was washed with in diethyl ether (4 X). Crude product was dissolved in water $(20 \mathrm{~mL})$ and made basic by using $1 \mathrm{M} \mathrm{NaOH}$. The reaction mixture was extracted with diethyl ether (3X). The organic phase was dried over $\mathrm{MgSO}_{4}$. The solvent was removed in vacuo and the obtained product was used in the next step without any future purification.

General Procedure D: Synthesis of trans-allylic amines from trans-allylic bromide by using Methoxyamine hydrochloride:

To a solution of trans-allylic bromide ( $3 \mathrm{mmol})$ and $\mathrm{K}_{2} \mathrm{CO}_{3}(2.08 \mathrm{~g}, 15 \mathrm{mmol})$ in $\mathrm{CH}_{3} \mathrm{CN}$ $(15.0 \mathrm{~mL})$ and DMF $(3 \mathrm{~mL})$, Methoxylamine hydrochloride (1.25 g, $15 \mathrm{mmol}$.) was added slowly at $0{ }^{\circ} \mathrm{C}$ and stirred at room temperature until the reaction was completed. The reaction mixture was quenched with $\mathrm{H}_{2} \mathrm{O}$ and extracted with DCM three times. The organic phase was washed with brine and dried over $\mathrm{MgSO}_{4}$. The solvent was removed in vacuo and the obtained product was used in the next step without any future purification.

\section{General Procedure E: Synthesis of trans-allylic diazoacetamides from trans-allylic amines:}

To a solution of trans-allylic amine $(3 \mathrm{mmol})$ and $\mathrm{K}_{2} \mathrm{CO}_{3}(2.08 \mathrm{~g}, 15 \mathrm{mmol})$ in DCM $(15.0 \mathrm{~mL})$, bromoacetyl bromide $(780 \mu \mathrm{l}, 9 \mathrm{mmol})$ was added slowly at $0{ }^{\circ} \mathrm{C}$ and stirred for 30 min. The reaction mixture was quenched with $\mathrm{H}_{2} \mathrm{O}$ and extracted with DCM three times. The organic phase was washed with brine and dried over $\mathrm{MgSO}_{4}$. The solvent was removed in vacuo and the obtained bromoacetate residue was used in the next step without any future purification. To the solution of the resulting bromoacetate and N',N-ditosylhydrazine $(2.04 \mathrm{~g}, 6.0 \mathrm{mmol})$ in 
THF (15.0 mL), DBU (2.28 mL, $15 \mathrm{mmol})$ was added dropwise at $0{ }^{\circ} \mathrm{C}$ and stirred for $30 \mathrm{~min}$. Reaction was quenched by aqueous saturated solution of $\mathrm{NaHCO}_{3}$. Reaction mixture was extracted with $\mathrm{Et}_{2} \mathrm{O}$ three times. The organic phase was washed with brine, dried over $\mathrm{MgSO}_{4}$ and evaporated to give crude diazo acetamide. The crude product was purified by column chromatography on silica gel with ethyl acetate/hexanes to afford the desired trans-allylic diazo acetamide product.

\section{General procedure F: Preparative-scale biocatalytic intramolecular cyclopropanation reactions using whole cells:}

These reactions were carried out on a 40 mL-scale using $39 \mathrm{~mL}$ of Mb(F43Y,H64V,V68A,I107V) (otherwise mentioned) expressing E. coli cells, $5 \mathrm{mM}$ of allylic diazo acetamide. In a typical procedure, freshly prepared allylic diazo acetamide $(0.2 \mathrm{mmol}$ in 1 $\mathrm{mL}$ of ethanol) was added slowly to a $125 \mathrm{~mL}$ Erlenmeyer flask containing a suspension of $\mathrm{Mb}$ expressing cells $\left(\mathrm{OD}_{600}=40\right.$ in $\left.\mathrm{KPi}, \mathrm{pH} 7\right)$ under argon pressure, equipped with a magnetic stir bar and sealed with a rubber septum. Reaction mixture stirred at room temperature for 3-5 hours. The reaction mixtures were extracted with diethyl ether $(20 \mathrm{~mL}$ x 3$)$ and the combined organic layers were dried over $\mathrm{MgSO}_{4}$ and concentrated under reduced pressure. The TON for the whole-cell reactions were calculated based on $\mathrm{Mb}$ concentration in the reaction mixture as measured via UV-vis spectroscopy using the CO-binding assay $\left(\varepsilon_{424}=187 \mathrm{mM}^{-1} \mathrm{~cm}^{-1}\right)$ after cell lysis. The crude product was purified by flash column chromatography using silica gel and ethyl acetate/hexanes as the eluent to isolate the intramolecular cyclopropanation product. The purified product was characterized by NMR, GC-MS, and chiral SFC or GC for stereoselectivity determination and they were used as authentic standards for the construction of the calibration curves (TON and \% conversion determination).

\section{General Procedure G: Synthesis of racemic standards by using Hemin}

Under standard reaction conditions, $500 \mu \mathrm{L}$ scale reactions were carried out using $20 \mu \mathrm{M}$ hemin (except $20 \mu \mathrm{M} \mathrm{Mb}$-WT variant for $\mathbf{2 h}$ ), $5 \mathrm{mM}$ allylic diazoacetate, and $10 \mathrm{mM}$ sodium dithionite. In a typical procedure, a solution containing hemin in potassium phosphate buffer (50 $\mathrm{mM}, \mathrm{pH}$ 7.0) with sodium dithionite was prepared in an anaerobic chamber. Reactions were 
initiated by addition of $10 \mu \mathrm{L}$ of diazoacetate from $0.5 \mathrm{M}$ stock solutions, and the reaction mixtures were stirred in the chamber for $12 \mathrm{~h}$ at room temperature. Reaction mixtures were extracted by using DCM and used for analysis.

\section{Reaction Analysis}

The reactions were analyzed by adding $25 \mu \mathrm{L}$ of internal standard (benzodioxole, $50 \mathrm{mM}$ in methanol) to a $500 \mu \mathrm{L}$ aliquot of the reaction mixture, followed by extraction with $500 \mu \mathrm{L}$ dichloromethane (DCM) and centrifugation at 14,000 rpm. The organic layer was collected and analyzed by SFC or GC-FID. The TON for the whole-cell reactions were calculated based on $\mathrm{Mb}$ concentration in the reaction mixture as measured via UV-vis using the CO-binding assay ( $\varepsilon_{424}=$ $187 \mathrm{mM}^{-1} \mathrm{~cm}^{-1}$ ) after cell lysis. Calibration curves of the different intramolecular cyclopropane products were constructed using authentic standards from the whole cell reactions (procedure F). Enantioselectivity was determined by using SFC or GC-FID using a chiral column as described below.

\section{Analytical Methods}

Gas chromatography (GC) analysis were carried out using a Shimadzu GC-2010 gas chromatograph equipped with a FID detector, and a Cyclosil-B column ( $30 \mathrm{~m} \times 0.25 \mathrm{~mm} \times 0.25$ $\mu \mathrm{m}$ film). The following GC methods were used for TON analysis and stereoisomer separation (\% ee analysis), $1 \mu \mathrm{L}$ injection, injector temp.: $200{ }^{\circ} \mathrm{C}$, detector temp: $300{ }^{\circ} \mathrm{C}$.

Gradient for method A: column temperature set at $140{ }^{\circ} \mathrm{C}$ for $3 \mathrm{~min}$, then to $160^{\circ} \mathrm{C}$ at $1.8^{\circ} \mathrm{C} / \mathrm{min}$, then to $165^{\circ} \mathrm{C}$ at $1.0^{\circ} \mathrm{C} / \mathrm{min}$, then to 245 at $25^{\circ} \mathrm{C} / \mathrm{min}$, then $245^{\circ} \mathrm{C}$ for $6 \mathrm{~min}$. Total run time was $28 \mathrm{~min}$.

Gradient for method B: column temperature set at $130^{\circ} \mathrm{C}$ for $2 \mathrm{~min}$, then to $150^{\circ} \mathrm{C}$ at $0.8^{\circ} \mathrm{C} / \mathrm{min}$, then to $180{ }^{\circ} \mathrm{C}$ at $0.6{ }^{\circ} \mathrm{C} / \mathrm{min}$, then $245{ }^{\circ} \mathrm{C}$ at $25{ }^{\circ} \mathrm{C} / \mathrm{min}, 245{ }^{\circ} \mathrm{C}$ hold for $3 \mathrm{~min}$. Total run time was $82 \mathrm{~min}$.

Gradient for method C: column temperature set at $120^{\circ} \mathrm{C}$ for $3 \mathrm{~min}$, then to $150^{\circ} \mathrm{C}$ at $0.8^{\circ} \mathrm{C} / \mathrm{min}$, then to $245^{\circ} \mathrm{C}$ at $25^{\circ} \mathrm{C} / \mathrm{min}, 245^{\circ} \mathrm{C}$ hold for $2 \mathrm{~min}$. Total run time was $46 \mathrm{~min}$.

Gradient for method D: column temperature set at $70^{\circ} \mathrm{C}$ for $3 \mathrm{~min}$, then to $160^{\circ} \mathrm{C}$ at $0.45^{\circ} \mathrm{C} / \mathrm{min}$, then to $240{ }^{\circ} \mathrm{C}$ at $25^{\circ} \mathrm{C} / \mathrm{min}$. Total run time was $206 \mathrm{~min}$. 
Gradient for method E: column temperature set at $180^{\circ} \mathrm{C}$, then to $192{ }^{\circ} \mathrm{C}$ at $0.2{ }^{\circ} \mathrm{C} / \mathrm{min}$, then to $245^{\circ} \mathrm{C}$ at $25^{\circ} \mathrm{C} / \mathrm{min}, 245^{\circ} \mathrm{C}$ hold for $3 \mathrm{~min}$. Total run time was $65 \mathrm{~min}$.

Gradient for method F: column temperature set at $160^{\circ} \mathrm{C}$ for $3 \mathrm{~min}$, then to $245{ }^{\circ} \mathrm{C}$ at $2{ }^{\circ} \mathrm{C} / \mathrm{min}$, $245{ }^{\circ} \mathrm{C}$ hold for $3 \mathrm{~min}$. Total run time was $48.5 \mathrm{~min}$.

Gradient for method G: column temperature set at $100^{\circ} \mathrm{C}$ for $3 \mathrm{~min}$, then to $140{ }^{\circ} \mathrm{C}$ at $0.4{ }^{\circ} \mathrm{C} / \mathrm{min}$ then to $245^{\circ} \mathrm{C}$ at $25^{\circ} \mathrm{C} / \mathrm{min}, 245^{\circ} \mathrm{C}$ hold for $2 \mathrm{~min}$. Total run time was $109 \mathrm{~min}$.

Table S7. Enantiomer resolution via chiral GC analysis.

\begin{tabular}{|c|c|c|c|}
\hline Product & Method & $\mathbf{t}_{\mathbf{R}}$ for $\mathbf{1}^{\text {st }} \mathbf{i s o m e r}(\mathbf{m i n})$ & $\mathbf{t}_{\mathbf{R}}$ for $\mathbf{2}^{\mathbf{n d}} \mathbf{i s o m e r}(\mathbf{m i n})$ \\
\hline $\mathbf{2 a}$ & A & 23.22 & 23.29 \\
\hline $\mathbf{2 b}$ & B & 59.61 & 60.70 \\
\hline $\mathbf{2 c}$ & B & 68.83 & 69.38 \\
\hline $\mathbf{2 e}$ & F & 26.09 & 26.29 \\
\hline $\mathbf{2 f}$ & A & 20.30 & 20.45 \\
\hline $\mathbf{2 g}$ & G & 21.07 & 21.31 \\
\hline $\mathbf{2 h}$ & A & 4.32 & 4.41 \\
\hline $\mathbf{2 i}$ & D & 180.55 & 181.08 \\
\hline $\mathbf{2 j}$ & B & 12.82 & 13.07 \\
\hline $\mathbf{2 k}$ & E & 47.15 & 47.66 \\
\hline $\mathbf{2 l}$ & C & 74.39 & 75.49 \\
\hline
\end{tabular}

Enantiomer resolution for compounds 2d, 2m, 2n were performed by Supercritical Fluid Chromatography (SFC) using a JASCO Analytical and Semi-Preparative SFC instrument equipped with a column oven $\left(35^{\circ} \mathrm{C}\right)$, photodiode array detector, a backpressure regulator $(12.0$ $\mathrm{MPa}$ ), a carbon dioxide pump and a sample injection volume of $3 \mu \mathrm{L}$. Daicel Chiralpak IA, IB IC or IF column $(0.46 \mathrm{~cm} \mathrm{ID} \times 25 \mathrm{~cm} \mathrm{~L})$ were used for separation of the enantiomers and \% ee determination. All samples were eluted using an isocratic solvent system with the indicated modifier in liquid $\mathrm{CO}_{2}$ at an elution rate of $4 \mathrm{~mL} / \mathrm{min}$ and detected at $\lambda=220 \mathrm{~nm}$. Total run time was $10.2 \mathrm{~min}$. 
Table S8. Enantiomer resolution via chiral SFC analysis.

\begin{tabular}{|c|c|c|c|c|}
\hline Product & Column & $\begin{array}{c}\text { Modifier } \\
\text { Solvent }\end{array}$ & $\begin{array}{c}\mathbf{t}_{\mathbf{R}} \text { for } \mathbf{1}^{\text {st }} \\
\text { enantiomer (min) }\end{array}$ & $\begin{array}{c}\mathbf{t}_{\mathbf{R}} \text { for } \mathbf{2}^{\text {nd }} \\
\text { enantiomer (min) }\end{array}$ \\
\hline $\mathbf{2 d}$ & IB & IPA (10\%) & 4.67 & 5.10 \\
\hline $\mathbf{2 m}$ & IA & IPA (20\%) & 3.92 & 4.55 \\
\hline $\mathbf{2 n}$ & IA & IPA (10\%) & 4.02 & 4.19 \\
\hline
\end{tabular}




\section{Compound Characterization Data}

\section{(E)-2-diazo-N-(3-(4-fluorophenyl)allyl)-N-methylacetamide (1a):}<smiles>CN(C/C=C/c1ccc(F)cc1)C(=O)C=[W]</smiles>

(E)-2-diazo-N-(3-(4-fluorophenyl)allyl)-N-methylacetamide (1a) was prepared according to the general procedure for the synthesis of trans-allylic diazo acetamide. Reaction mixture was purified by silica gel column chromatography with $30 \%$ EtOAc/hexanes as an eluent to give the desired product as pale-yellow liquid in $48 \%$ yield (yield of step E). ${ }^{1} \mathrm{H} N M R$ $\left(500 \mathrm{MHz}, \mathrm{CDCl}_{3}\right) \delta 7.13-7.07(\mathrm{~m}, 4 \mathrm{H}), 5.78(\mathrm{dd}, J=8.8,1.6 \mathrm{~Hz}, 1 \mathrm{H}), 5.58(\mathrm{dd}, J=4.3,2.2$ Hz, 1H), 3.73 (dd, $J=10.5,8.4 \mathrm{~Hz}, 1 \mathrm{H}), 3.24$ (dd, $J=10.6,2.6 \mathrm{~Hz}, 1 \mathrm{H}), 2.86$ (s, 3H), 2.77 $2.68(\mathrm{~m}, 1 \mathrm{H}) ;{ }^{13} \mathrm{C} \mathrm{NMR}\left(126 \mathrm{MHz}, \mathrm{CDCl}_{3}\right) \delta 166.5,162.4,133.7,129.40(\mathrm{~d}, J=8.3 \mathrm{~Hz}), 116.95$ $(\mathrm{d}, J=21.7 \mathrm{~Hz}), 101.8,97.3,54.4,37.1,30.5 .{ }^{19} \mathrm{~F}$ NMR (376 MHz, CDCl3): $\delta$-113.2.

\section{N-cinnamyl-2-diazo-N-methylacetamide (1b):}<smiles>CN(C/C=C/c1ccccc1)C(=O)C=[W]</smiles>

N-cinnamyl-2-diazo-N-methylacetamide

(1b) was prepared according to the general procedure for the synthesis of trans-allylic diazo acetamide. Reaction mixture was purified by silica gel column chromatography with $30 \%$ EtOAc/hexanes as an eluent to give the desired product as paleyellow liquid in 74\% yield (yield of step E). (mixture of rotamers 90:10), major rotamer: ${ }^{1} \mathrm{H}$ NMR $\left(400 \mathrm{MHz}, \mathrm{CDCl}_{3}\right) \delta 7.46-7.22(\mathrm{~m}, 5 \mathrm{H}), 6.51(\mathrm{~d}, J=15.7 \mathrm{~Hz}, 1 \mathrm{H}), 6.15(\mathrm{~d}, J=15.6 \mathrm{~Hz}$, 1H), 5.04 (s, 1H), 4.08 (br s, 2H), 2.94 (br s, 3H); ${ }^{13} \mathrm{C}$ NMR (101 MHz, $\left.\mathrm{CDCl}_{3}\right) \delta 164.0,134.5$, $130.5,127.4,126.8,126.0,124.6,51.9,44.6,32.3$.

\section{N-cinnamyl-2-diazo-N-methoxyacetamide (1c):}

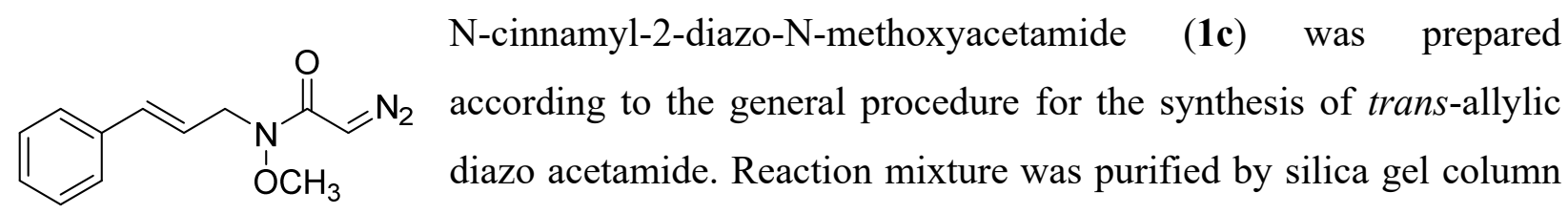
chromatography with $20 \%$ EtOAc/hexanes as an eluent to give the desired product as paleyellow liquid 71\% yield (yield of step E). ${ }^{1} \mathrm{H}$ NMR $\left(500 \mathrm{MHz}, \mathrm{CDCl}_{3}\right) \delta 7.36(\mathrm{~d}, J=7.4 \mathrm{~Hz}$, 2H), 7.29 (t, $J=7.5 \mathrm{~Hz}, 2 \mathrm{H}), 7.22$ (t, $J=7.2 \mathrm{~Hz}, 1 \mathrm{H}), 6.58(\mathrm{~d}, J=15.8 \mathrm{~Hz}, 1 \mathrm{H}), 6.22(\mathrm{dt}, J=$ 
15.7, 6.6 Hz, 1H), $5.34(\mathrm{~s}, 1 \mathrm{H}), 4.35(\mathrm{~d}, J=6.5 \mathrm{~Hz}, 2 \mathrm{H}), 3.67(\mathrm{~s}, 3 \mathrm{H}) ;{ }^{13} \mathrm{C} \mathrm{NMR}(126 \mathrm{MHz}$, $\left.\mathrm{CDCl}_{3}\right) \delta 169.3,137.2,134.6,129.3,128.6,127.2,124.2,63.4,49.9,47.5$.

\section{N-cinnamyl-2-diazo-N-ethylacetamide (1d):}

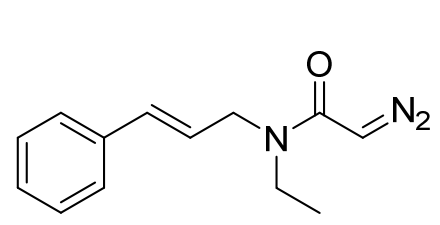

$\mathrm{N}$-cinnamyl-2-diazo-N-ethylacetamide (1d) was prepared according to the general procedure for the synthesis of trans-allylic diazo acetamide. Reaction mixture was purified by silica gel column chromatography with $20 \% \mathrm{EtOAc/hexanes} \mathrm{as} \mathrm{an} \mathrm{eluent} \mathrm{to} \mathrm{give} \mathrm{the}$ desired product as pale-yellow liquid in $80 \%$ yield (yield of step E). (mixture of rotamers 80:20), major rotamer: ${ }^{1} \mathrm{H}$ NMR $\left(400 \mathrm{MHz}, \mathrm{CDCl}_{3}\right) \delta 7.47-7.24(\mathrm{~m}, 5 \mathrm{H}), 6.48(\mathrm{~d}, J=15.7 \mathrm{~Hz}, 1 \mathrm{H})$, $6.30-6.03$ (m, 1H), 4.98 (s, 1H), 4.03 (br s, 2H), 3.34 (br s, 2H), 1.16 (br s, 3H); ${ }^{13} \mathrm{C}$ NMR (101 $\left.\mathrm{MHz}, \mathrm{CDCl}_{3}\right) \delta$ 163.6, 135.3, 134.5, 127.4, 126.8, 126.0, 124.5, 49.1, 44.8, 39.8, 11.8.

\section{N-cinnamyl-2-diazoacetamide (1e):}<smiles>N#CC(=O)NC/C=C/c1ccccc1</smiles>

N-cinnamyl-2-diazoacetamide (1e) was prepared according to the general procedure for the synthesis of trans-allylic diazo acetamide. Reaction mixture was purified by silica gel column chromatography with $90 \%$ EtOAc/hexanes as an eluent to give the desired product as yellow solid in $35 \%$ yield (yield of step E). ${ }^{1} \mathrm{H}$ NMR (500 MHz, MeOD) $\delta 7.67$ (d, $\left.J=8.1 \mathrm{~Hz}, 1 \mathrm{H}\right), 7.35$ (d, $J=7.5 \mathrm{~Hz}$, 2H), 7.27 (t, $J=7.4 \mathrm{~Hz}, 2 \mathrm{H}), 7.18(\mathrm{t}, J=7.2 \mathrm{~Hz}, 1 \mathrm{H}), 6.50$ (d, $J=15.8 \mathrm{~Hz}, 1 \mathrm{H}), 6.19$ (dt, $J=$ $15.8,5.9 \mathrm{~Hz}, 1 \mathrm{H}), 5.14(\mathrm{~s}, 1 \mathrm{H}), 3.96(\mathrm{~d}, J=5.7 \mathrm{~Hz}, 2 \mathrm{H}) ;{ }^{13} \mathrm{C} \mathrm{NMR}\left(126 \mathrm{MHz}, \mathrm{CDCl}_{3}\right) \delta 171.8$, $137.6,132.1,128.9,127.9,126.7,126.2,70.4,41.1$.

\section{(E)-2-diazo-N-(3-(furan-2-yl)allyl)-N-methylacetamide (1f):}

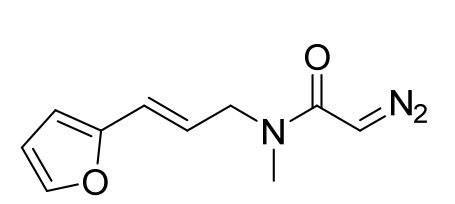

(E)-2-diazo-N-(3-(furan-2-yl)allyl)-N-methylacetamide

(1f) was gel column chromatography with $50 \%$ EtOAc/hexanes as an eluent to give the desired product as pale-yellow liquid in $44 \%$ yield (yield of step E). (mixture of rotamers $60: 40$ ), major rotamer: ${ }^{1} \mathrm{H}$ 
$\operatorname{NMR}\left(500 \mathrm{MHz}, \mathrm{CDCl}_{3}\right) \delta 7.34(\mathrm{~s}, 1 \mathrm{H}), 6.39(\mathrm{~d}, J=17.4 \mathrm{~Hz}, 1 \mathrm{H}), 6.35-6.18(\mathrm{~m}, 2 \mathrm{H}), 6.06(\mathrm{~d}$, $J=15.6 \mathrm{~Hz}, 1 \mathrm{H}), 4.98(\mathrm{~s}, 1 \mathrm{H}), 4.04$ (br s, 2H), $2.92(\mathrm{~s}, 3 \mathrm{H}) ;{ }^{13} \mathrm{C} \mathrm{NMR}\left(126 \mathrm{MHz}, \mathrm{CDCl}_{3}\right) \delta$ 166.7, 142.9, 139.9, 130.2, 112.1, 111.6, 109.5, 54.2, 47.2, 33.6.

\section{2-diazo-N-methyl-N-(3-methylbut-2-en-1-yl)acetamide (1g):}<smiles>CC(C)=CCN(C)C(=O)C=[W]</smiles>

2-diazo-N-methyl-N-(3-methylbut-2-en-1-yl)acetamide (1g) was prepared according to the general procedure for the synthesis of trans-allylic diazo acetamide. Reaction mixture was purified by silica gel column chromatography with $30 \%$ EtOAc/hexanes as an eluent to give the desired product as paleyellow liquid in $43 \%$ yield (yield of step E). ${ }^{1} \mathrm{H}$ NMR $\left(500 \mathrm{MHz}, \mathrm{CDCl}_{3}\right) \delta 5.11(\mathrm{t}, J=5.9 \mathrm{~Hz}$, 1H), 4.93 (s, 1H), 3.86 (br s, 2H), 2.84 (s, 3H), 1.74 (s, 3H), 1.69 (s, 3H); ${ }^{13} \mathrm{C}$ NMR (126 MHz, $\left.\mathrm{CDCl}_{3}\right) \delta 166.2,136.9,120.3,48.6,47.0,34.5,26.4,18.6$.

\section{N-allyl-2-diazo-N-methylacetamide (1h):}

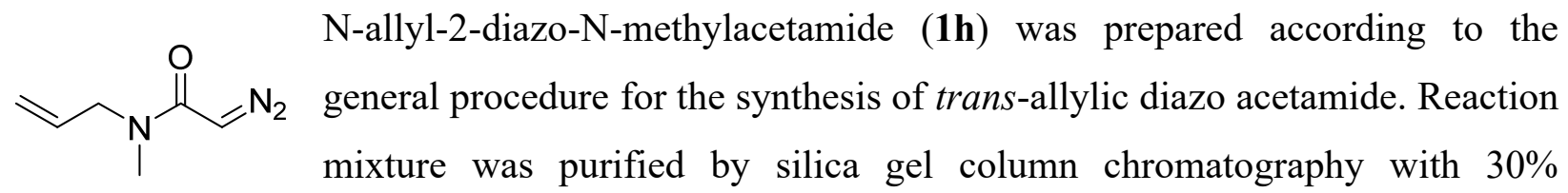

EtOAc/hexanes as an eluent to give the desired product as pale-yellow liquid in $43 \%$ yield (yield of step E). (mixture of rotamers 80:20), major rotamer: ${ }^{1} \mathrm{H}$ NMR (500 $\left.\mathrm{MHz}, \mathrm{CDCl}_{3}\right) \delta 5.86-$ $5.70(\mathrm{~m}, 1 \mathrm{H}), 5.20(\mathrm{~d}, J=11.3 \mathrm{~Hz}, 2 \mathrm{H}), 4.97(\mathrm{~s}, 1 \mathrm{H}), 3.90(\mathrm{br} \mathrm{s}, 2 \mathrm{H}), 2.89(\mathrm{br} \mathrm{s}, 3 \mathrm{H}) ;{ }^{13} \mathrm{C} \mathrm{NMR}$ $\left(126 \mathrm{MHz}, \mathrm{CDCl}_{3}\right) \delta 166.6,133.4,117.8,55.3,47.0,34.8$.

\section{N-allyl-2-diazo-N-phenylacetamide (1i):}

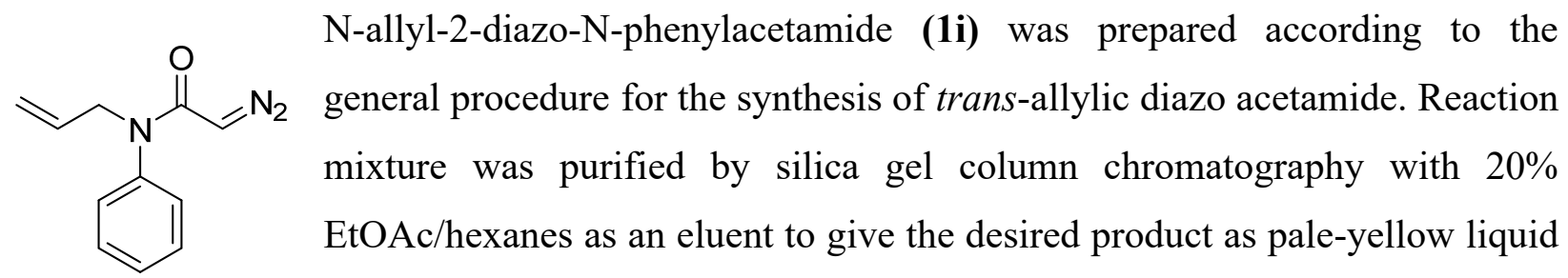


in $85 \%$ yield (yield of step E). ${ }^{1} \mathrm{H}$ NMR $\left(500 \mathrm{MHz}^{\mathrm{CDCl}} 3\right) \delta 7.37(\mathrm{t}, J=7.5 \mathrm{~Hz}, 2 \mathrm{H}), 7.31(\mathrm{t}, J=$ $6.9 \mathrm{~Hz}, 1 \mathrm{H}), 7.15(\mathrm{~d}, J=7.2 \mathrm{~Hz}, 2 \mathrm{H}), 5.94-5.78(\mathrm{~m}, 1 \mathrm{H}), 5.12-5.06(\mathrm{~m}, 2 \mathrm{H}), 4.43(\mathrm{~s}, 1 \mathrm{H})$, $4.31(\mathrm{~d}, J=6.2 \mathrm{~Hz}, 2 \mathrm{H}) ;{ }^{13} \mathrm{C} \mathrm{NMR}\left(126 \mathrm{MHz}, \mathrm{CDCl}_{3}\right) \delta 166.3,142.3,134.1,130.4,129.1$, $128.8,118.6,52.8,48.1$.

\section{N,N-diallyl-2-diazoacetamide (1j):}

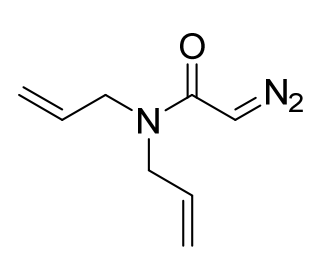

$\mathrm{N}, \mathrm{N}$-diallyl-2-diazoacetamide (1j) was prepared according to the general

procedure for the synthesis of trans-allylic diazo acetamide. Reaction mixture was purified by silica gel column chromatography with $30 \%$ EtOAc/hexanes as an eluent to give the desired product as pale-yellow liquid in $69 \%$ yield (yield of step E). (mixture of rotamers 85:15), Major rotamer: ${ }^{1} \mathrm{H}$ NMR (500 MHz, $\left.\mathrm{CDCl}_{3}\right) \delta 5.79-5.66(\mathrm{~m}, 2 \mathrm{H}), 5.15(\mathrm{~d}, J=10.9 \mathrm{~Hz}, 4 \mathrm{H}), 4.90($ br s, $1 \mathrm{H}), 3.82$ (br s, $\left.4 \mathrm{H}\right) ;{ }^{13} \mathrm{C}$ NMR (126 MHz, $\left.\mathrm{CDCl}_{3}\right) \delta 166.7,132.1,119.6,52.6,49.5$.

\section{(E)-N-(3-(4-chlorophenyl)allyl)-2-diazo-N-methoxyacetamide (1k):}<smiles>CON(C/C=C/c1ccc(Cl)cc1)C(=O)C=[W]</smiles>

(E)-N-(3-(4-chlorophenyl)allyl)-2-diazo-N-methoxyacetamide (1k) was prepared according to the general procedure for the synthesis of trans-allylic diazo acetamide. Reaction mixture was purified by silica gel column chromatography with $20 \%$ EtOAc/hexanes as an eluent to give the desired product as pale-yellow liquid in $76 \%$ yield (yield of step E). ${ }^{1} \mathrm{H} \mathrm{NMR}\left(500 \mathrm{MHz}, \mathrm{CDCl}_{3}\right) \delta 7.25(\mathrm{~d}, J=6.3 \mathrm{~Hz}, 4 \mathrm{H}), 6.51(\mathrm{~d}, J=15.8 \mathrm{~Hz}, 1 \mathrm{H})$, $6.18(\mathrm{dt}, J=15.8,6.5 \mathrm{~Hz}, 1 \mathrm{H}), 5.33(\mathrm{~s}, 1 \mathrm{H}), 4.33(\mathrm{dd}, J=6.5,1.2 \mathrm{~Hz}, 2 \mathrm{H}), 3.66(\mathrm{~s}, 3 \mathrm{H}) ;{ }^{13} \mathrm{C}$ NMR $\left(126 \mathrm{MHz} \mathrm{CDCl}_{3}\right) \delta 169.4,135.7,134.2,133.3,129.5,128.4,125.0,63.3,49.6,47.45$.

\section{(E)-2-diazo-N-methoxy-N-(3-(4-(trifluoromethyl)phenyl)allyl)acetamide (11):}<smiles>CON(C/C=C/c1ccc(C(F)(F)F)cc1)C(=O)C=[W]</smiles>

(E)-2-diazo-N-methoxy-N-(3-(4-

(trifluoromethyl)phenyl)allyl)acetamide (11) was prepared according to the general procedure for the synthesis of transallylic diazo acetamide. Reaction mixture was purified by 
silica gel column chromatography with 20\% EtOAc/hexanes as an eluent to give the desired product as pale-yellow liquid in 78\% yield (yield of step E). ${ }^{1} \mathrm{H} \mathrm{NMR}\left(500 \mathrm{MHz}, \mathrm{CDCl}_{3}\right) \delta 7.56$ $(\mathrm{d}, J=8.1 \mathrm{~Hz}, 2 \mathrm{H}), 7.47(\mathrm{~d}, J=8.1 \mathrm{~Hz}, 2 \mathrm{H}), 6.62(\mathrm{~d}, J=15.9 \mathrm{~Hz}, 1 \mathrm{H}), 6.33(\mathrm{dt}, J=15.8,6.4 \mathrm{~Hz}$, $1 \mathrm{H}), 5.38(\mathrm{~s}, 1 \mathrm{H}), 4.39$ (d, $J=6.3 \mathrm{~Hz}, 2 \mathrm{H}), 3.70(\mathrm{~s}, 3 \mathrm{H}) ;{ }^{13} \mathrm{C} \mathrm{NMR}\left(126 \mathrm{MHz}, \mathrm{CDCl}_{3}\right) \delta 169.4$, 140.6, 133.1, 127.4, 127.1, 126.3, 126.2, $126.163 .3,49.6,47.5 .{ }^{19} \mathrm{~F}$ NMR (376 MHz, CDCl3): $\delta$ -62.7 .

\section{(E)-2-diazo-N-methoxy-N-(3-(3-methoxyphenyl)allyl)acetamide (1 m):}

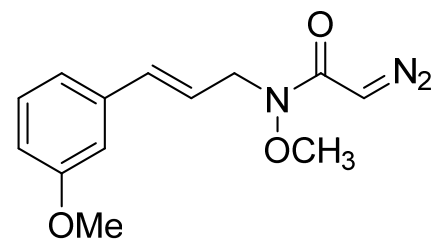

(E)-2-diazo-N-methoxy-N-(3-(3-methoxyphenyl)allyl)acetamide (1m) was prepared according to the general procedure for the synthesis of trans-allylic diazo acetamide. Reaction mixture was purified by silica gel column chromatography with $20 \%$ EtOAc/hexanes as an eluent to give the desired product as pale-yellow liquid in $62 \%$ yield (yield of step E). ${ }^{1} \mathrm{H}$ NMR (500 MHz, $\left.\mathrm{CDCl}_{3}\right) \delta 7.20$ (t, $\left.J=7.9 \mathrm{~Hz}, 1 \mathrm{H}\right), 6.95(\mathrm{~d}, J=7.6 \mathrm{~Hz}, 1 \mathrm{H}), 6.89$ $(\mathrm{s}, 1 \mathrm{H}), 6.78(\mathrm{dd}, J=8.2,2.1 \mathrm{~Hz}, 1 \mathrm{H}), 6.55(\mathrm{~d}, J=15.8 \mathrm{~Hz}, 1 \mathrm{H}), 6.21(\mathrm{dt}, J=15.8,6.6 \mathrm{~Hz}, 1 \mathrm{H})$, $5.34(\mathrm{~s}, 1 \mathrm{H}), 4.34(\mathrm{~d}, J=6.3 \mathrm{~Hz}, 2 \mathrm{H}), 3.79(\mathrm{~s}, 3 \mathrm{H}), 3.67(\mathrm{~s}, 3 \mathrm{H}) ;{ }^{13} \mathrm{C} \mathrm{NMR}\left(126 \mathrm{MHz}, \mathrm{CDCl}_{3}\right) \delta$ $169.4,160.5,138.6,134.5,130.3,124.6,119.9,114.4,112.4,63.4,56.0,49.8,47.5$.

\section{(E)-2-diazo-N-methoxy-N-(3-(o-tolyl)allyl)acetamide (1n):}

(E)-2-diazo-N-methoxy-N-(3-(o-tolyl)allyl)acetamide (1n) was<smiles>CON(C/C=C/c1ccccc1C)C(=O)C=[W]</smiles>

prepared according to the general procedure for the synthesis of trans-allylic diazo acetamide. Reaction mixture was purified by silica gel column chromatography with $20 \%$ EtOAc/hexanes as an eluent to give the desired product as pale-yellow liquid in 65\% yield (yield of step E). (mixture of rotamers 90:10) ${ }^{1} \mathrm{H}$ NMR $\left(500 \mathrm{MHz}, \mathrm{CDCl}_{3}\right) \delta 7.48-7.37(\mathrm{~m}, 1 \mathrm{H}), 7.18-7.09(\mathrm{~m}, 3 \mathrm{H}), 6.79$ $(\mathrm{d}, J=15.7 \mathrm{~Hz}, 1 \mathrm{H}), 6.10(\mathrm{dt}, J=15.7,6.6 \mathrm{~Hz}, 1 \mathrm{H}), 5.34(\mathrm{~s}, 1 \mathrm{H}), 4.37(\mathrm{dd}, J=6.6,1.1 \mathrm{~Hz}, 2 \mathrm{H})$, $3.68(\mathrm{~s}, 3 \mathrm{H}), 2.33(\mathrm{~s}, 3 \mathrm{H}) ;{ }^{13} \mathrm{C} \mathrm{NMR}\left(126 \mathrm{MHz}, \mathrm{CDCl}_{3}\right) \delta 169.4,136.3,136.2,132.5,131.0$, $128.5,126.9,126.5,125.6,63.5,50.2,47.4,20.5$. 


\section{Characterization data for intramolecular cyclopropanation products prepared by enzymatic reactions on preparative scale.}

(1R,5S,6S)-6-(4-fluorophenyl)-3-methyl-3-azabicyclo[3.1.0]hexan-2-one (2a):

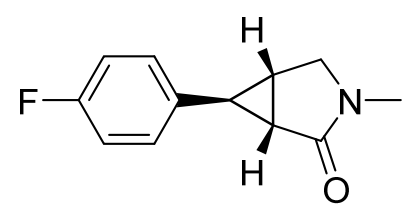

(1R,5S,6S)-6-(4-fluorophenyl)-3-methyl-3-azabicyclo[3.1.0]hexan-2one (2a) was prepared according to the general Procedure $\mathbf{F}$ with $E$. coli cells expressing $\mathrm{Mb}(\mathrm{F} 43 \mathrm{Y}, \mathrm{H} 64 \mathrm{~V}, \mathrm{~V} 68 \mathrm{~A}, \mathrm{I107V})$ to afford the product as a white solid, $36.9 \mathrm{mg}, 90 \%$ yield. GC-MS m/z (\% relative intensity): 207(1.8), 205(0.5), 174(27.0), 173(12.0), 130(67.4), 129(100), 115(86.6), 91(15.6), 77(13.7); ${ }^{1} \mathrm{H}$ NMR (500 MHz, $\left.\mathrm{CDCl}_{3}\right) \delta 7.07$ - $6.92(\mathrm{~m}, 4 \mathrm{H}), 3.66(\mathrm{dd}, J=10.6,5.8 \mathrm{~Hz}, 1 \mathrm{H})$, $3.49(\mathrm{dd}, J=10.5,10.5 \mathrm{~Hz}, 1 \mathrm{H}), 2.82(\mathrm{~s}, 3 \mathrm{H}), 2.21(\mathrm{dd}, J=6.3,6.3 \mathrm{~Hz}, 1 \mathrm{H}), 2.11$ (dd, $J=9.0$, $5.4 \mathrm{~Hz}, 1 \mathrm{H}), 2.08-2.03(\mathrm{~m}, 1 \mathrm{H}) ;{ }^{13} \mathrm{C} \mathrm{NMR}\left(126 \mathrm{MHz}, \mathrm{CDCl}_{3}\right) \delta 174.2,162.32(\mathrm{~d}, J=245.0$ $\mathrm{Hz}), 135.43(\mathrm{~d}, J=3.0 \mathrm{~Hz}), 128.13(\mathrm{~d}, J=8.0 \mathrm{~Hz}), 116.11(\mathrm{~d}, J=21.5 \mathrm{~Hz}), 52.5,31.3,30.1$, 30.0, 22.1. ${ }^{19} \mathrm{~F}$ NMR (376 MHz, CDCl3): $\delta-116.4$.

(1R,5S,6S)-3-methyl-6-phenyl-3-azabicyclo[3.1.0]hexan-2-one (2b):

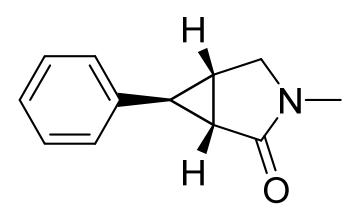

(1R,5S,6S)-3-methyl-6-phenyl-3-azabicyclo[3.1.0]hexan-2-one (2b) was prepared according to the general Procedure $\mathbf{F}$ with $E$. coli cells expressing $\mathrm{Mb}(\mathrm{F} 43 \mathrm{Y}, \mathrm{H} 64 \mathrm{~V}, \mathrm{~V} 68 \mathrm{~A}, \mathrm{I107V})$ to afford the product as a white solid, $30.7 \mathrm{mg}, 82 \%$ yield. GC-MS m/z (\% relative intensity): 188(1.2),

187(9.3), 186(5.9), 130(100), 129(53.7), 116(12.7), 115(42.5), 77(5.7); ${ }^{1} \mathrm{H}$ NMR (500 MHz, $\left.\mathrm{CDCl}_{3}\right) \delta 7.26-7.21(\mathrm{~m}, 2 \mathrm{H}), 7.17(\mathrm{t}, J=7.3 \mathrm{~Hz}, 1 \mathrm{H}), 7.01(\mathrm{~d}, J=7.5 \mathrm{~Hz}, 2 \mathrm{H}), 3.62(\mathrm{dd}, J=$ 10.6, $5.8 \mathrm{~Hz}, 1 \mathrm{H}), 3.45(\mathrm{dd}, J=10.5,10.5 \mathrm{~Hz}, 1 \mathrm{H}), 2.78(\mathrm{~s}, 3 \mathrm{H}), 2.20$ (dd, $J=6.2,6.2 \mathrm{~Hz}, 1 \mathrm{H})$, $2.11(\mathrm{dd}, J=9.6,5.9 \mathrm{~Hz}, 1 \mathrm{H}), 2.05-2.00(\mathrm{~m}, 1 \mathrm{H}) ;{ }^{13} \mathrm{C} \mathrm{NMR}\left(126 \mathrm{MHz}, \mathrm{CDCl}_{3}\right) \delta 174.3,139.9$, $129.3,127.3,126.6,52.6,31.4,30.7,30.1,22.3$.

(1R,5S,6S)-3-methoxy-6-phenyl-3-azabicyclo[3.1.0]hexan-2-one (2c):

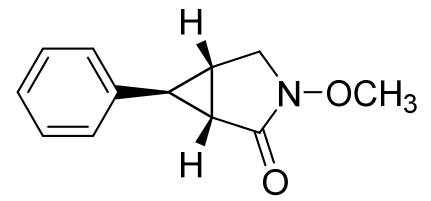

(1R,5S,6S)-3-methoxy-6-phenyl-3-azabicyclo[3.1.0]hexan-2-one (2c) was prepared according to the general Procedure F with E. coli cells expressing $\mathrm{Mb}(\mathrm{F} 43 \mathrm{Y}, \mathrm{H} 64 \mathrm{~V}, \mathrm{~V} 68 \mathrm{~A}, \mathrm{I107V})$ to afford the product as a 
white solid, $36.2 \mathrm{mg}, 89 \%$ yield. GC-MS m/z (\% relative intensity): 203(13.1), 172(22.2), 144(66.7), 130(76.5), 116(83.2), 115(100), 91(11.0), 77(12.7); ${ }^{1} \mathrm{H}$ NMR (500 MHz, $\left.\mathrm{CDCl}_{3}\right) \delta$ $7.25(\mathrm{t}, J=7.4 \mathrm{~Hz}, 2 \mathrm{H}), 7.18(\mathrm{t}, J=7.3 \mathrm{~Hz}, 1 \mathrm{H}), 7.01(\mathrm{~d}, J=7.3 \mathrm{~Hz}, 2 \mathrm{H}), 3.84(\mathrm{dd}, J=9.5,5.6$ Hz, 1H), 3.73 (s, 3H), 3.62 (dd, $J=9.4,9.4 \mathrm{~Hz}, 1 \mathrm{H}), 2.13$ (dd, $J=6.1,6.1 \mathrm{~Hz}, 1 \mathrm{H}), 2.11-2.03$ (m, 2H); ${ }^{13} \mathrm{C}$ NMR $\left(126 \mathrm{MHz}, \mathrm{CDCl}_{3}\right) \delta 169.9,138.9,129.4,127.6,126.7,62.9,48.5,30.8,27.6$, 19.5.

(1R,5S,6S)-3-ethyl-6-phenyl-3-azabicyclo[3.1.0]hexan-2-one (2d):

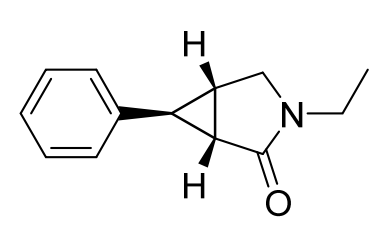

(1R,5S,6S)-3-ethyl-6-phenyl-3-azabicyclo[3.1.0]hexan-2-one (2d) was prepared according to the general Procedure F with E. coli cells expressing $\mathrm{Mb}(\mathrm{F} 43 \mathrm{Y}, \mathrm{H} 64 \mathrm{~V}, \mathrm{~V} 68 \mathrm{~A}, \mathrm{I1} 107 \mathrm{~V})$ to afford the product as a white solid, $33 \mathrm{mg}, \quad 82 \%$ yield. GC-MS m/z (\% relative intensity): 201(3.87), 130(100), 129(52.3), 115(35.5), 77(4.7); ${ }^{1} \mathrm{H}$ NMR (500 MHz, $\left.\mathrm{CDCl}_{3}\right) \delta 7.24$ (t, $J=$ $7.4 \mathrm{~Hz}, 2 \mathrm{H}), 7.17$ (t, $J=7.2 \mathrm{~Hz}, 1 \mathrm{H}), 7.01$ (d, $J=7.1 \mathrm{~Hz}, 2 \mathrm{H}), 3.63$ (dd, $J=10.5,5.9 \mathrm{~Hz}, 1 \mathrm{H})$, $3.45(\mathrm{dd}, J=10.4,10.4 \mathrm{~Hz}, 1 \mathrm{H}), 3.26(\mathrm{~m}, 2 \mathrm{H}), 2.21(\mathrm{dd}, J=5.7,5.7 \mathrm{~Hz}, 1 \mathrm{H}), 2.10(\mathrm{dd}, J=9.5$, $5.9 \mathrm{~Hz}, 1 \mathrm{H}), 2.02-1.94(\mathrm{~m}, 1 \mathrm{H}), 1.08(\mathrm{t}, J=7.2 \mathrm{~Hz}, 3 \mathrm{H}) ;{ }^{13} \mathrm{C} \mathrm{NMR}\left(126 \mathrm{MHz}, \mathrm{CDCl}_{3}\right) \delta 173.9$, $139.9,129.2,127.2,126.6,49.7,37.6,31.7,30.6,22.2,13.5$.

(1R,5S,6S)-6-phenyl-3-azabicyclo[3.1.0]hexan-2-one (2e):

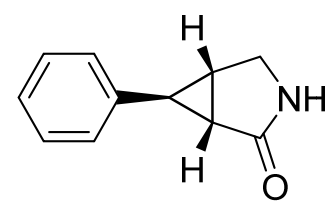

(1R,5S,6S)-6-phenyl-3-azabicyclo[3.1.0]hexan-2-one (2e) was prepared according to the general Procedure $\mathbf{F}$ with E. coli cells expressing $\mathrm{Mb}(\mathrm{F} 43 \mathrm{Y}, \mathrm{H} 64 \mathrm{~V}, \mathrm{~V} 68 \mathrm{~A}, \mathrm{I107V})$ to afford the product as a white solid, $8 \mathrm{mg}$, $23 \%$ yield. GC-MS m/z (\% relative intensity): 174(1.3), 173(10.8), 172(7.4), 153(9.3), 130(100), 115(48.7), 91(9.0); ${ }^{1} \mathrm{H}$ NMR (500 MHz, $\left.\mathrm{CDCl}_{3}\right) \delta 7.29$ (t, $J=7.4$ $\mathrm{Hz}, 2 \mathrm{H}), 7.21$ (t, $J=7.0 \mathrm{~Hz}, 1 \mathrm{H}), 7.05(\mathrm{~d}, J=7.4 \mathrm{~Hz}, 2 \mathrm{H}), 5.35$ (s, 1H), 3.66 (dd, $J=10.3,5.8$ $\mathrm{Hz}, 1 \mathrm{H}), 3.54$ (dd, $J=10.3,10.3 \mathrm{~Hz}, 1 \mathrm{H}), 2.25$ (dd, $J=5.2,5.2 \mathrm{~Hz}, 1 \mathrm{H}), 2.17-2.13(\mathrm{~m}, 2 \mathrm{H})$; ${ }^{13} \mathrm{C}$ NMR $\left(126 \mathrm{MHz}, \mathrm{CDCl}_{3}\right) \delta 166.6,139.8,129.3,127.3,126.6,70.4,45.2,30.3,25.1$.

(1R,5S,6S)-6-(furan-2-yl)-3-methyl-3-azabicyclo[3.1.0]hexan-2-one (2f): 


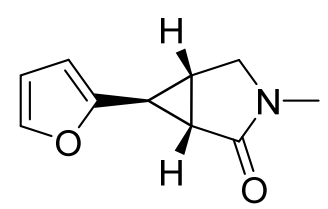

(1R,5S,6S)-6-(furan-2-yl)-3-methyl-3-azabicyclo[3.1.0]hexan-2-one

was prepared according to the general Procedure $\mathbf{F}$ with E. coli cells expressing $\mathrm{Mb}(\mathrm{F} 43 \mathrm{Y}, \mathrm{H} 64 \mathrm{~V}, \mathrm{~V} 68 \mathrm{~A}, \mathrm{I107V})$ to afford the product as a white solid, $24.8 \mathrm{mg}, 70 \%$ yield. GC-MS m/z (\% relative intensity): 178(3.7), 177(31.4), 121(13.0), 120(100), 106(11.7), 91(67.1), 65(8.4); ${ }^{1} \mathrm{H}$ NMR (500 MHz, $\left.\mathrm{CDCl}_{3}\right) \delta 7.25$ (d, $J=0.9 \mathrm{~Hz}, 1 \mathrm{H}), 6.28$ (dd, $J=3.1,1.8 \mathrm{~Hz}, 1 \mathrm{H}), 6.05(\mathrm{~d}, J=3.1 \mathrm{~Hz}, 1 \mathrm{H}), 3.63(\mathrm{dd}, J=10.6$, $5.7 \mathrm{~Hz}, 1 \mathrm{H}), 3.45(\mathrm{dd}, J=10.6,10,6 \mathrm{~Hz}, 1 \mathrm{H}), 2.79(\mathrm{~s}, 3 \mathrm{H}), 2.32-2.20(\mathrm{~m}, 2 \mathrm{H}), 2.11-2.02(\mathrm{~m}$, $1 \mathrm{H}) ;{ }^{13} \mathrm{C}$ NMR $\left(126 \mathrm{MHz}, \mathrm{CDCl}_{3}\right) \delta 173.9,152.7,142.0,111.2,106.1,52.1,30.0,29.1,24.0$, 19.9 .

(1S,5R)-3,6,6-trimethyl-3-azabicyclo[3.1.0] hexan-2-one (2g):

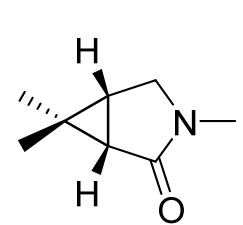

(1S,5R)-3,6,6-trimethyl-3-azabicyclo[3.1.0]hexan-2-one (2g) was prepared according to the general Procedure F with E. coli cells expressing Mb(H64V, $\mathrm{V} 68 \mathrm{G}$ ) to afford the product as a white solid, $13 \mathrm{mg}$, 45\% yield. GC-MS m/z (\% relative intensity): 140(6.3), 139(67.8), 138(7.0), 124(15.4), 111(11.4), 98(49.3), 82(62.3), 67(100); ${ }^{1} \mathrm{H}$ NMR (500 MHz, $\left.\mathrm{CDCl}_{3}\right) \delta 3.52$ (dd, $\left.J=10.8,6.6 \mathrm{~Hz}, 1 \mathrm{H}\right), 3.10(\mathrm{~d}, J=$ $11.0 \mathrm{~Hz}, 1 \mathrm{H}), 2.73(\mathrm{~s}, 3 \mathrm{H}), 1.80(\mathrm{~d}, J=6.5 \mathrm{~Hz}, 1 \mathrm{H}), 1.59$ (dd, $J=6.6,6.6 \mathrm{~Hz}, 1 \mathrm{H}), 1.11(\mathrm{~s}, 3 \mathrm{H})$, $0.99(\mathrm{~s}, 3 \mathrm{H}) ;{ }^{13} \mathrm{C} \mathrm{NMR}\left(126 \mathrm{MHz}, \mathrm{CDCl}_{3}\right) \delta 173.7,49.0,33.9,29.4,26.4,24.8,22.4,14.5$.

(1R,5S)-3-methyl-3-azabicyclo[3.1.0]hexan-2-one (2h):

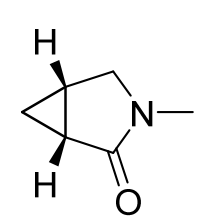

(1R,5S)-3-methyl-3-azabicyclo[3.1.0]hexan-2-one (2h) was prepared according to the general Procedure F with E. coli cells expressing Mb(H64V,V68G) to afford the product as a green solid, $15.8 \mathrm{mg}, 71 \%$ yield. GC-MS $\mathrm{m} / \mathrm{z}$ (\% relative intensity): 112(6.9), 111(100), 110(31.4), 83(13.6), 82(23.5), 68(24.8), 55(22.8); ${ }^{1} \mathrm{H}$ NMR $\left(500 \mathrm{MHz}, \mathrm{CDCl}_{3}\right) \delta 3.52(\mathrm{dd}, J=10.3,5.9 \mathrm{~Hz}, 1 \mathrm{H}), 3.28(\mathrm{dd}, J=10.5,10.5 \mathrm{~Hz}, 1 \mathrm{H}), 2.74(\mathrm{~s}$, $3 \mathrm{H}), 1.95-1.87(\mathrm{~m}, 1 \mathrm{H}), 1.87-1.79(\mathrm{~m}, 1 \mathrm{H}), 1.08$ (ddd, $J=8.0,8.0,4.8 \mathrm{~Hz}, 2 \mathrm{H}), 0.59(\mathrm{~m}, 1 \mathrm{H})$; ${ }^{13} \mathrm{C}$ NMR $\left(126 \mathrm{MHz}, \mathrm{CDCl}_{3}\right) \delta 169.0,52.1,30.0,20.9,13.5,12.5$.

(1R,5S)-3-phenyl-3-azabicyclo[3.1.0]hexan-2-one (2i): 


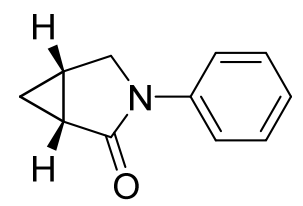

(1R,5S)-3-phenyl-3-azabicyclo[3.1.0]hexan-2-one (2i) was prepared according to the general Procedure $\mathbf{F}$ with $E$. coli cells expressing $\mathrm{Mb}(\mathrm{H} 64 \mathrm{~V}, \mathrm{~V} 68 \mathrm{G})$ to afford the product as a white liquid, $28.8 \mathrm{mg}$, 83\% yield. GC-MS m/z (\% relative intensity): 174(12.4), 173(100), 172(19.5), 144(25.0), 119(13.3), 104(27.2), 77(26.8); ${ }^{1} \mathrm{H}$ NMR (500 MHz, $\left.\mathrm{CDCl}_{3}\right) \delta 7.49$ (d, $\left.J=8.0 \mathrm{~Hz}, 2 \mathrm{H}\right), 7.30$ (t, $J$ $=7.9 \mathrm{~Hz}, 2 \mathrm{H}), 7.08(\mathrm{t}, J=7.3 \mathrm{~Hz}, 1 \mathrm{H}), 4.02(\mathrm{dd}, J=10.0,5.9 \mathrm{~Hz}, 1 \mathrm{H}), 3.71(\mathrm{dd}, J=10.0,10.0$ $\mathrm{Hz}, 1 \mathrm{H}), 2.12-2.03(\mathrm{~m}, 1 \mathrm{H}), 2.01-1.90(\mathrm{~m}, 1 \mathrm{H}), 1.17$ (ddd, $J=8.0,8.0,4.9 \mathrm{~Hz}, 8 \mathrm{H}), 0.76(\mathrm{~m}$, $1 \mathrm{H}) ;{ }^{13} \mathrm{C} \mathrm{NMR}\left(126 \mathrm{MHz}, \mathrm{CDCl}_{3}\right) \delta 175.1,140.1,129.6,125.0,120.5,51.1,22.5,13.4,12.1$.

\section{(1R,5S)-3-allyl-3-azabicyclo[3.1.0]hexan-2-one (2j):}

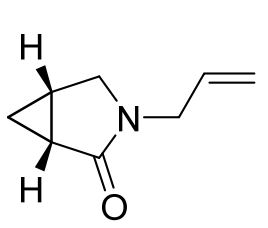

(1R,5S)-3-allyl-3-azabicyclo[3.1.0] hexan-2-one (2j) was prepared according to

the general Procedure F with $E$. coli cells expressing $\mathrm{Mb}(\mathrm{H} 64 \mathrm{~V}, \mathrm{~V} 68 \mathrm{G})$ to afford the product as a white solid, $11.8 \mathrm{mg}, 43 \%$ yield. GC-MS m/z (\% relative intensity): 138(9.0), 137(100), 136(75.2), 122(25.8), 110(31.1), 96(15.1), 94(41.8), 68(29.9); ${ }^{1} \mathrm{H}$ NMR (500 MHz, $\left.\mathrm{CDCl}_{3}\right) \delta 5.76-5.58(\mathrm{~m}, 1 \mathrm{H}), 5.13(\mathrm{~d}, J=$ $16.0 \mathrm{~Hz}, 2 \mathrm{H}), 3.77$ (qd, $J=15.3,5.9 \mathrm{~Hz}, 2 \mathrm{H}), 3.48$ (dd, $J=10.3,5.9 \mathrm{~Hz}, 1 \mathrm{H}), 3.26$ (dd, $J=10.3$, $10.3 \mathrm{~Hz}, 1 \mathrm{H}), 1.99-1.90(\mathrm{~m}, 1 \mathrm{H}), 1.88-1.77(\mathrm{~m}, 1 \mathrm{H}), 1.10(\mathrm{ddd}, J=8.0,8.0,4.9 \mathrm{~Hz}, 1 \mathrm{H}), 0.60$ (m, $1 \mathrm{H}) ;{ }^{13} \mathrm{C}$ NMR $\left(126 \mathrm{MHz}, \mathrm{CDCl}_{3}\right) \delta 175.6,133.5,118.5,49.5,45.5,21.0,13.5,12.6$.

(1R,5S,6S)-6-(4-chlorophenyl)-3-methoxy-3-azabicyclo[3.1.0]hexan-2-one (2k):

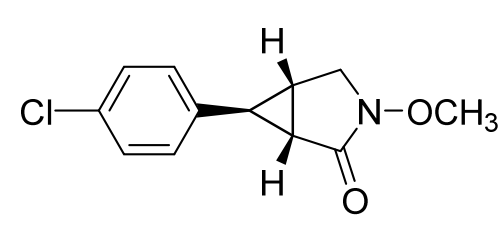

(1R,5S,6S)-6-(4-chlorophenyl)-3-methoxy-3azabicyclo[3.1.0]hexan-2-one (2k) was prepared according to the general Procedure $\mathbf{F}$ with $E$. coli cells expressing $\mathrm{Mb}(\mathrm{F} 43 \mathrm{Y}, \mathrm{H} 64 \mathrm{~V}, \mathrm{~V} 68 \mathrm{~A}, \mathrm{I107V})$ to afford the product as a white solid, $32.8 \mathrm{mg}, 69 \%$ yield. GC-MS m/z (\% relative intensity): 239(3.4), 237(9.9), 180(17.1), 178(53.1), 164(38.7), 129(44.7), 115(100), 89(9.9); ${ }^{1} \mathrm{H}$ NMR (500 MHz, $\left.\mathrm{CDCl}_{3}\right) \delta 7.23$ (d, $J=$ $8.5 \mathrm{~Hz}, 2 \mathrm{H}), 6.95(\mathrm{~d}, J=8.4 \mathrm{~Hz}, 2 \mathrm{H}), 3.85$ (dd, $J=9.6,5.4 \mathrm{~Hz}, 1 \mathrm{H}), 3.74$ (s, 3H), 3.63 (dd, $J=$ 
10.3, $10.3 \mathrm{~Hz}, 1 \mathrm{H}), 2.12(\mathrm{dd}, J=6.4,6.4 \mathrm{~Hz}, 1 \mathrm{H}), 2.09-2.01(\mathrm{~m}, 2 \mathrm{H}) ;{ }^{13} \mathrm{C} \mathrm{NMR}(126 \mathrm{MHz}$, $\left.\mathrm{CDCl}_{3}\right) \delta 169.5,137.4,133.4,129.5,128.1,63.0,48.4,30.2,27.7,19.6$.

(1R,5S,6S)-3-methoxy-6-(4-(trifluoromethyl)phenyl)-3-azabicyclo[3.1.0]hexan-2-one (2I):

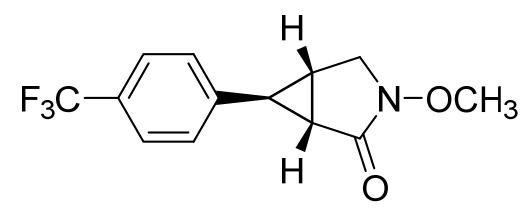

(1R,5S,6S)-3-methoxy-6-(4-(trifluoromethyl)phenyl)-3-

azabicyclo[3.1.0] hexan-2-one (2l) was prepared according to the general Procedure $\mathbf{F}$ with $E$. coli cells expressing $\mathrm{Mb}(\mathrm{F} 43 \mathrm{Y}, \mathrm{H} 64 \mathrm{~V}, \mathrm{~V} 68 \mathrm{~A}, \mathrm{I107V})$ to afford the product as a white solid, $36.3 \mathrm{mg}, 67 \%$ yield. GC-MS m/z (\% relative intensity): 271(12.2), 241(26.8), 212(58.3), 198(45.8), 184(44.2), 129(52.0), 115(100), 68(32.0); ${ }^{1} \mathrm{H}$ NMR (500 MHz, $\left.\mathrm{CDCl}_{3}\right) \delta 7.52(\mathrm{~d}, J=$ $7.9 \mathrm{~Hz}, 2 \mathrm{H}), 7.12$ (d, $J=7.9 \mathrm{~Hz}, 2 \mathrm{H}), 3.88$ (dd, $J=9.6,5.8 \mathrm{~Hz}, 1 \mathrm{H}), 3.75$ (s, 3H), 3.66 (dd, $J=$ 9.7, $9.7 \mathrm{~Hz}, 1 \mathrm{H}), 2.20(\mathrm{dd}, J=6.2,6.2 \mathrm{~Hz}, 1 \mathrm{H}), 2.17-2.08(\mathrm{~m}, 2 \mathrm{H}) ;{ }^{13} \mathrm{C}$ NMR $(126 \mathrm{MHz}$, $\left.\mathrm{CDCl}_{3}\right) \delta 169.3,143.1,129.13(\mathrm{~d}, J=30.0 \mathrm{~Hz}), 127.0,126.33(\mathrm{~d}, J=3.7 \mathrm{~Hz}), 63.0,48.4,30.3$, 28.0, 20.0. ${ }^{19} \mathrm{~F}$ NMR (376 MHz, CDCl3): $\delta-62.7$.

(1R,5S,6S)-3-methoxy-6-(3-methoxyphenyl)-3-azabicyclo[3.1.0]hexan-2-one (2m):

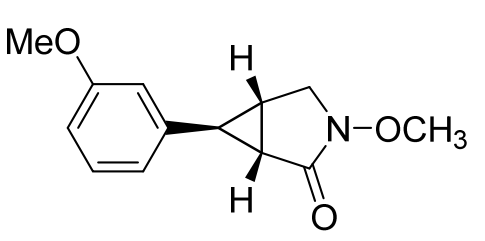

(1R,5S,6S)-3-methoxy-6-(3-methoxyphenyl)-3azabicyclo[3.1.0]hexan-2-one (2l) was prepared according to the general Procedure $\mathbf{F}$ with $E$. coli cells expressing $\mathrm{Mb}(\mathrm{F} 43 \mathrm{Y}, \mathrm{H} 64 \mathrm{~V}, \mathrm{~V} 68 \mathrm{~A}, \mathrm{I107V})$ to afford the product as a white solid, $42 \mathrm{mg}$, 90\% yield. GC-MS m/z (\% relative intensity): 234(7.4), 233(49.1), 202(52,7), 174(88.6), 146(100), 131(95.4), 115(53.7), 103(60.6), 77(36.1); ${ }^{1} \mathrm{H}$ NMR (500 MHz, $\left.\mathrm{CDCl}_{3}\right) \delta$ $7.20(\mathrm{t}, J=7.9 \mathrm{~Hz}, 1 \mathrm{H}), 6.76(\mathrm{dd}, J=8.2,2.0 \mathrm{~Hz}, 1 \mathrm{H}), 6.64(\mathrm{~d}, J=7.7 \mathrm{~Hz}, 1 \mathrm{H}), 6.60(\mathrm{~s}, 1 \mathrm{H})$, 3.87 (dd, $J=9.6,5.6 \mathrm{~Hz}, 1 \mathrm{H}), 3.79$ (s, 3H), 3.77 (s, 3H), 3.66 (dd, $J=9.4,9.4 \mathrm{~Hz}, 1 \mathrm{H}), 2.15$ (dd, $J=6.4,6.4 \mathrm{~Hz}, 1 \mathrm{H}), 2.14-2.08(\mathrm{~m}, 2 \mathrm{H}) ;{ }^{13} \mathrm{C} \mathrm{NMR}\left(126 \mathrm{MHz}, \mathrm{CDCl}_{3}\right) \delta 169.8,160.5,140.5$, $130.4,119.0,112.8,112.8,62.9,56.0,48.5,30.8,27.6,19.5$.

(1R,5S,6S)-3-methoxy-6-(0-tolyl)-3-azabicyclo[3.1.0]hexan-2-one (2n):

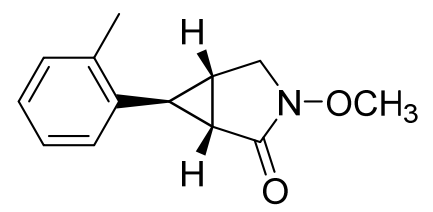

(1R,5S,6S)-3-methoxy-6-(o-tolyl)-3-azabicyclo[3.1.0]hexan-2-one

(2n) was prepared according to the general Procedure $\mathbf{F}$ with $E$. coli 
cells expressing $\mathrm{Mb}(\mathrm{F} 43 \mathrm{Y}, \mathrm{H} 64 \mathrm{~V}, \mathrm{~V} 68 \mathrm{~A}, \mathrm{I107V})$ to afford the product as a white solid, $35.2 \mathrm{mg}$, $81 \%$ yield. GC-MS m/z (\% relative intensity): 217(4.4), 158(100), 157(16.9), 143(15.1), 130(24.6), 129(58.5), 115(41.4); ${ }^{1} \mathrm{H}$ NMR (500 MHz, $\left.\mathrm{CDCl}_{3}\right) \delta 7.18-7.06$ (m, 3H), 6.94 (d, $J=$ $7.2 \mathrm{~Hz}, 1 \mathrm{H}), 3.89$ (dd, $J=9.4,5.9 \mathrm{~Hz}, 1 \mathrm{H}), 3.76(\mathrm{~s}, 3 \mathrm{H}), 3.65$ (dd, $J=9.4,9.4 \mathrm{~Hz}, 1 \mathrm{H}), 2.40$ (s, $3 \mathrm{H}), 2.15(\mathrm{dd}, J=6.7,6.7 \mathrm{~Hz}, 1 \mathrm{H}), 2.11-2.01(\mathrm{~m}, 2 \mathrm{H}) ;{ }^{13} \mathrm{C} \mathrm{NMR}\left(126 \mathrm{MHz}, \mathrm{CDCl}_{3}\right) \delta 170.2$, $138.5,136.3,130.9,127.9,126.8,126.4,62.9,48.5,29.2,25.9,20.4,17.8$.

((1R,2S,3S)-2-((methoxyamino)methyl)-3-phenylcyclopropyl)(phenyl)methanone (3):

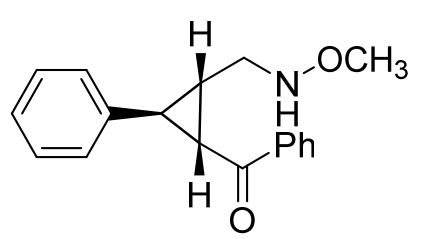
((1R,2S,3S)-2-((methoxyamino)methyl)-3-phenylcyclopropyl) (phenyl)methanone (3) was prepared according to a modified version of a reported procedure. ${ }^{5}$ To a solution of $(1 \mathrm{R}, 5 \mathrm{~S}, 6 \mathrm{~S})-3-$ methoxy-6-phenyl-3-azabicyclo[3.1.0]hexan-2-one (2c) $(30 \mathrm{mg}, 1$ equiv) in $2 \mathrm{ml} \mathrm{THF}$, of phenyl magnesium bromide (1.5 equiv.) was added at $0{ }^{\circ} \mathrm{C}$ over $10 \mathrm{~min}$. and the reaction mixture was stirred for $6 \mathrm{~h}$ at room temperature. After the reaction was finished, the THF was removed under reduced pressure and the residue was further purified by silica-gel chromatography using $20 \%$ EtOAc/hexanes as eluent to afford the product as a white solid, 35 $\mathrm{mg}, 83 \%$ yield. GC-MS m/z (\% relative intensity): 281(0.5), 203(13.6), 173(13.6), 172(22.4), 144(64.3), 130(73.1), 115(100), 91(11.5), 77(13.3); ${ }^{1} \mathrm{H}$ NMR (500 MHz, $\left.\mathrm{CDCl}_{3}\right) \delta 8.00$ (d, $J=$ $7.5 \mathrm{~Hz}, 2 \mathrm{H}), 7.54$ (t, $J=7.4 \mathrm{~Hz}, 1 \mathrm{H}), 7.45(\mathrm{t}, J=7.6 \mathrm{~Hz}, 2 \mathrm{H}), 7.32-7.26(\mathrm{~m}, 2 \mathrm{H}), 7.23-7.13$ $(\mathrm{m}, 3 \mathrm{H}), 5.51(\mathrm{~s}, 1 \mathrm{H}), 3.35(\mathrm{~s}, 3 \mathrm{H}), 3.33(\mathrm{dd}, J=13.8,5.6 \mathrm{~Hz}, 1 \mathrm{H}), 3.17(\mathrm{dd}, J=13.8,8.3 \mathrm{~Hz}$, $1 \mathrm{H}), 3.05(\mathrm{dd}, J=9.0,5.1 \mathrm{~Hz}, 1 \mathrm{H}), 2.96-2.88(\mathrm{~m}, 1 \mathrm{H}), 2.36-2.27(\mathrm{~m}, 1 \mathrm{H}) ;{ }^{13} \mathrm{C}$ NMR $(126$ $\left.\mathrm{MHz}, \mathrm{CDCl}_{3}\right) \delta 198.0,140.8,139.1,133.6,129.3,129.3,128.9,127.3,127.2,62.4,49.0,34.0$, $32.9,31.8$.

\section{(1R,5S,6S)-3-ethyl-6-phenyl-3-azabicyclo[3.1.0]hexane (4):}

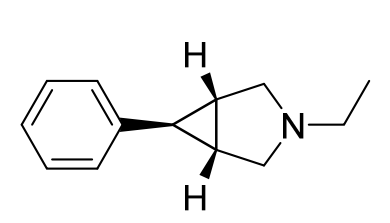

(1R,5S,6S)-3-ethyl-6-phenyl-3-azabicyclo[3.1.0]hexane (4) was was prepared according to a reported procedure.1 (1R,5S,6S)-3-ethyl-6phenyl-3-azabicyclo[3.1.0]hexan-2-one (2d) $(30 \mathrm{mg}, 0.15 \mathrm{mmol})$ in dry THF was added dropwise to a suspension of LiAlH4 (1 equiv) in dry THF at $0{ }^{\circ} \mathrm{C}$. The resulting mixture was stirred for $6 \mathrm{~h}$ at room temperature and then quenched 
with aqueous diethyl ether and stirred for $1 \mathrm{~h}$ at room temperature. After filtration through a pad of Celite, the filtrate was dried over $\mathrm{MgSO}_{4}$ and concentrated to give a residue, which was further purified by silica-gel chromatography using $10 \% \mathrm{MeOH} / \mathrm{DCM}$ as eluent to afford the product as a white solid, $23 \mathrm{mg}, 82 \%$ yield. GC-MS m/z (\% relative intensity): 188(14.2), 187(100), 172(93.7), 158(20.5), 130(59.2), 115(87.0), 91(78.7); ${ }^{1} \mathrm{H}$ NMR (500 MHz, $\left.\mathrm{CDCl}_{3}\right) \delta$ $7.24(\mathrm{~m}, 2 \mathrm{H}), 7.13$ (t, $J=7.4 \mathrm{~Hz}, 1 \mathrm{H}), 7.04$ (d, $J=7.5 \mathrm{~Hz}, 2 \mathrm{H}), 3.23$ (d, $J=9.0 \mathrm{~Hz}, 2 \mathrm{H}), 2.53$ (dd, $J=14.4,7.2 \mathrm{~Hz}, 2 \mathrm{H}), 2.44(\mathrm{~d}, J=8.8 \mathrm{~Hz}, 2 \mathrm{H}), 2.30-2.24(\mathrm{~m}, 1 \mathrm{H}), 1.71-1.65(\mathrm{~m}, 1 \mathrm{H})$, $1.27-1.25(\mathrm{~m}, J=1.0 \mathrm{~Hz}, 1 \mathrm{H}), 1.10(\mathrm{t}, J=7.0 \mathrm{~Hz}, 3 \mathrm{H}) ;{ }^{13} \mathrm{C} \mathrm{NMR}\left(126 \mathrm{MHz}, \mathrm{CDCl}_{3}\right) \delta 143.6$, $129.2,129.1,129.0,126.3,126.0,56.1,50.3,30.4,28.2,25.1,14.6$. 


\section{X-ray crystallographic analyses}

X-ray crystal diffraction data were collected using a XtaLab Synergy-S Dualflex diffractometer equipped with a HyPix-6000HE HPC area detector for data collection at $100.00(10) \mathrm{K}$. A preliminary set of cell constants and an orientation matrix were calculated from reflections harvested from a sampling of reciprocal space. The full data collection was carried out using a PhotonJet $(\mathrm{Cu})$ X-ray Source with frame times of 0.05 and 0.06 seconds and a detector distance of $31.2 \mathrm{~mm}$. Series of frames were collected in $0.50^{\circ}$ steps in $\omega$ at different $2 \theta$, $\kappa$, and $\phi$ settings. The intensity data were scaled and corrected for absorption, and final cell constants were calculated from the xyz centroids of strong reflections from the actual data collections after integration. Space groups were determined based on systematic absences and intensity statistics.

Structures were solved using SHELXT(Sheldrick, G. M. SHELXT, version 2014/5; University of Göttingen: Göttingen, Germany)and refined using SHELXL (against $F^{2}$ ) (Sheldrick, G. M. SHELXL-2016/6;Acta Crystallogr. 2015, C71, 3-8.).All non-hydrogen atoms were refined with anisotropic displacement parameters. All hydrogen atoms were placed in ideal positions and refined as riding atoms with relative isotropic displacement parameters.Absolute configurations for $\mathbf{2} \mathbf{b}$, and $\mathbf{2 k}$ were determined by anomalous dispersion effects (Parsons, S; Flack, H. D.; Wagner, T. Acta Crystallogr. 2013, B69, 249-259). See Figure S4-S5 and Table S9-S10 for additional crystal data and structure refinement information. The crystallographic data and coordinates for compounds $2 \mathrm{~b}, 2 \mathrm{k}$ were deposited in the Cambridge Crystallographic Data Centre (CCDC) under entries 1962324 through 1962325. 
Table S9. Crystal data and structure refinement for (1R,5S,6S)-3-methyl-6-phenyl-3azabicyclo[3.1.0]hexan-2-one (2b). Cambridge Crystallographic Data Centre (CCDC) entry: 1962325.

Identification code

Empirical formula

Formula weight

Temperature

Wavelength

Crystal system

Space group

Unit cell dimensions

Volume

Z

Density (calculated)

Absorption coefficient

$F(000)$

Crystal color, morphology

Crystal size

Theta range for data collection

Index ranges

Reflections collected

Independent reflections

Observed reflections

Completeness to theta $=74.504^{\circ}$

Absorption correction

Max. and min. transmission

Refinement method

Data / restraints / parameters

Goodness-of-fit on $F^{2}$

Final $R$ indices $[I>2 \operatorname{sigma}(I)]$

$R$ indices (all data)

Absolute structure parameter

Largest diff. peak and hole 2b

C12 H13 N O

187.23

100.00(10) K

$1.54184 \AA$

monoclinic

$P 2_{1}$

$a=5.6803(2) \AA$

$\alpha=90^{\circ}$

$b=9.2798(3) \AA$

$\beta=90.739(3)^{\circ}$

$c=9.3092(3) \AA$

$\gamma=90^{\circ}$

490.67(3) $\AA^{3}$

2

$1.267 \mathrm{Mg} / \mathrm{m}^{3}$

$0.638 \mathrm{~mm}^{-1}$

200

colourless, needle

$0.145 \times 0.066 \times 0.035 \mathrm{~mm}^{3}$

4.751 to $77.848^{\circ}$

$-6 \leq h \leq 7,-11 \leq k \leq 11,-11 \leq l \leq 11$

7207

$2033[R($ int $)=0.0666]$

1854

$99.9 \%$

Multi-scan

1.00000 and 0.61067

Full-matrix least-squares on $F^{2}$

$2033 / 1 / 128$

1.057

$R 1=0.0438, w R 2=0.1144$

$R 1=0.0482, w R 2=0.1183$

$-0.3(3)$

0.156 and -0.220 e. $\AA^{-3}$ 
Table S10. Crystal data and structure refinement for (1R,5S,6S)-6-(4-chlorophenyl)-3-methoxy3-azabicyclo[3.1.0] hexan-2-one 2k). Cambridge Crystallographic Data Centre (CCDC) entry: 1962324.

Identification code

Empirical formula

Formula weight

Temperature

Wavelength

Crystal system

Space group

Unit cell dimensions

Volume

Z

Density (calculated)

Absorption coefficient

$F(000)$

Crystal color, morphology

Crystal size

Theta range for data collection

Index ranges

Reflections collected

Independent reflections

Observed reflections

Completeness to theta $=74.504^{\circ}$

Absorption correction

Max. and min. transmission

Refinement method

Data / restraints / parameters

Goodness-of-fit on $F^{2}$

Final $R$ indices $[I>2 \operatorname{sigma}(I)]$

$R$ indices (all data)

Absolute structure parameter

Largest diff. peak and hole
$2 k$

$\mathrm{C} 12 \mathrm{H} 12 \mathrm{Cl} N \mathrm{O} 2$

237.68

100.00(10) K

$1.54184 \AA$

orthorhombic

$P 2_{1} 2_{1} 2_{1}$

$a=8.2690(2) \AA$

$\alpha=90^{\circ}$

$b=9.9012(2) \AA$

$\beta=90^{\circ}$

$c=13.5986(2) \AA$

$\gamma=90^{\circ}$

$1113.36(4) \AA^{3}$

4

$1.418 \mathrm{Mg} / \mathrm{m}^{3}$

$2.913 \mathrm{~mm}^{-1}$

496

colourless, block

$0.248 \times 0.204 \times 0.113 \mathrm{~mm}^{3}$

5.527 to $78.818^{\circ}$

$-9 \leq h \leq 10,-12 \leq k \leq 12,-17 \leq l \leq 17$

11869

$2356[R(\mathrm{int})=0.0428]$

2306

$100.0 \%$

Multi-scan

1.00000 and 0.74976

Full-matrix least-squares on $F^{2}$

$2356 / 0 / 146$

1.107

$R 1=0.0296, w R 2=0.0702$

$R 1=0.0306, w R 2=0.0721$

$-0.008(8)$

0.167 and -0.239 e. $\AA^{-3}$ 


\section{References:}

(1) Bordeaux, M., Tyagi, V., and Fasan, R. Highly diastereoselective and enantioselective olefin cyclopropanation using engineered myoglobin-based catalysts, Angew. Chem. Int. Ed. 2015, 54, 1744-1748.

(2) Bajaj, P., Sreenilayam, G., Tyagi, V., and Fasan, R. Gram-scale synthesis of chiral cyclopropane containing drugs and drug precursors with engineered myoglobin catalysts featuring complementary stereoselectivity, Angew. Chem. Int. Ed. 2016, 55, 16110-16114.

(3) Chandgude, A., Ren, X., and Fasan, R. Stereodivergent intramolecular cyclopropanation enabled by engineered carbene transferases J. Am. Chem. Soc. 2019, 141, 9145-9150.

(4) Mandour, H. S. A., Chanthamath, S., Shibatomi, K., Iwasa, S., Inter- and intramolecular cyclopropanations of diazo weinrebamides catalyzed by ruthenium(ii)-amm-pheox, Adv. Synth. Catal. 2017, 359, 1742-1746.

(5) Culbertson, D.S. and Olson, J.S. The role of heme in the unfolding and assembly of myoglobin, Biochemistry 2010; 49 (29), 6052-6063

(6) Antonini, E.; Brunori, M. Hemoglobin and myoglobin in their reactions with ligands. 1971, NorthHolland Pub. Co, Amsterdam. 


\section{NMR Spectra}

(E)-2-diazo-N-(3-(4-fluorophenyl)allyl)-N-methylacetamide (1a): $500 \mathrm{MHz}{ }^{1} \mathrm{H}$ spectrum, 126 $\mathrm{MHz}{ }^{13} \mathrm{C}$ spectrum and $376 \mathrm{MHz}{ }^{19} \mathrm{~F}$ spectrum in $\mathrm{CDCl}_{3}$ solvent

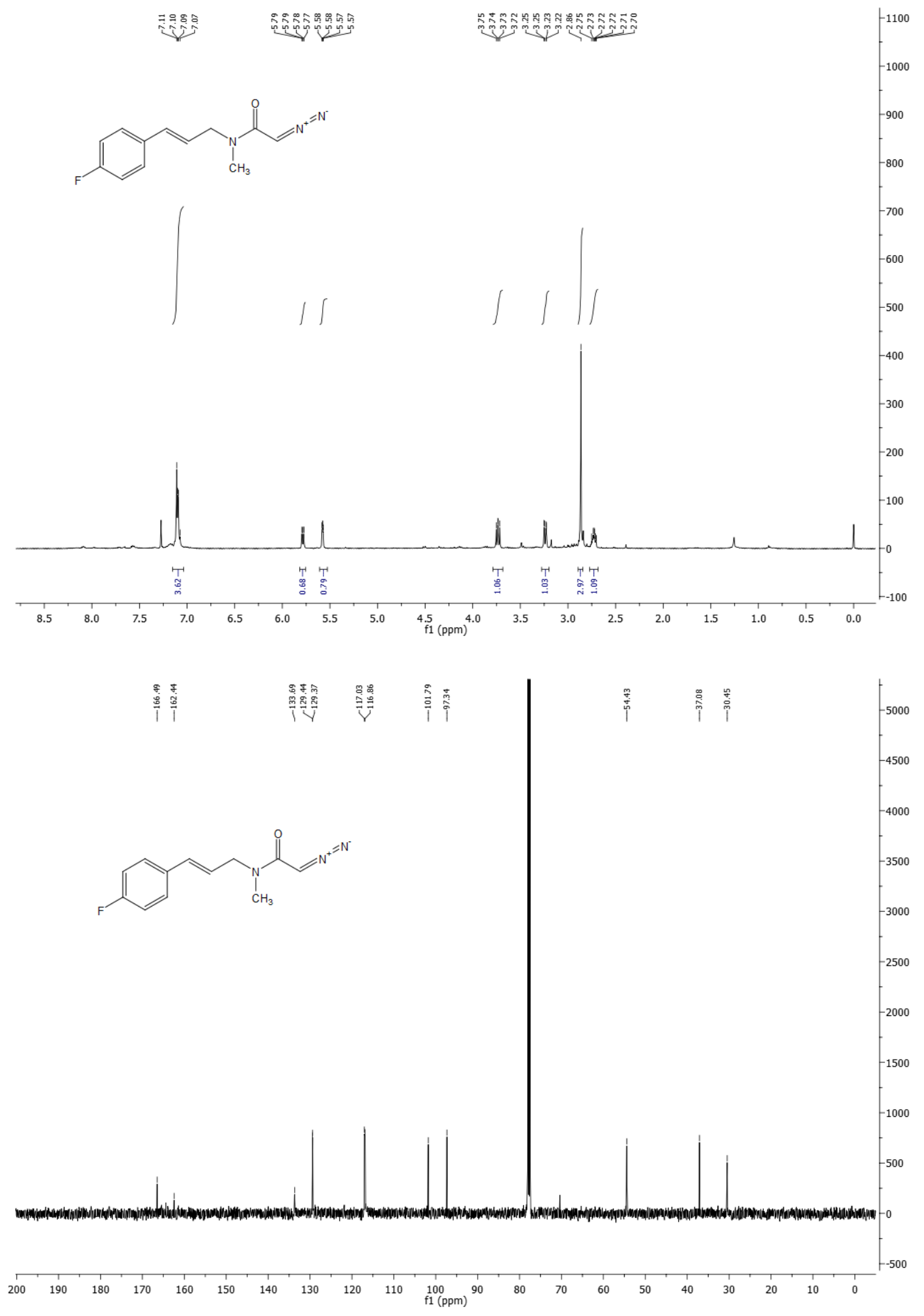




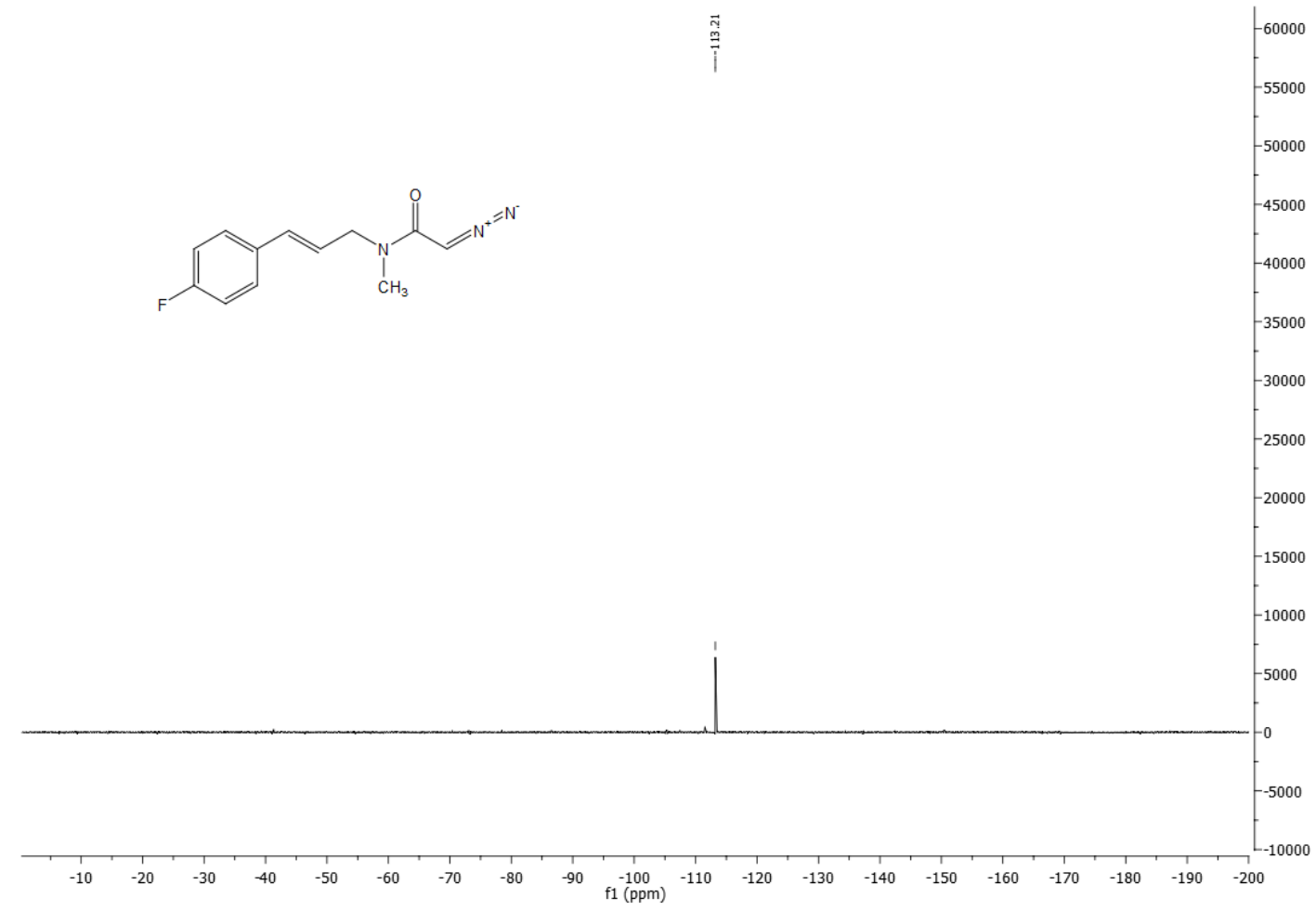


N-cinnamyl-2-diazo-N-methylacetamide (1b): rotamer mixture 90:10

$400 \mathrm{MHz}{ }^{1} \mathrm{H}$ spectrum and $126 \mathrm{MHz}{ }^{13} \mathrm{C}$ spectrum in $\mathrm{CDCl}_{3}$ solvent

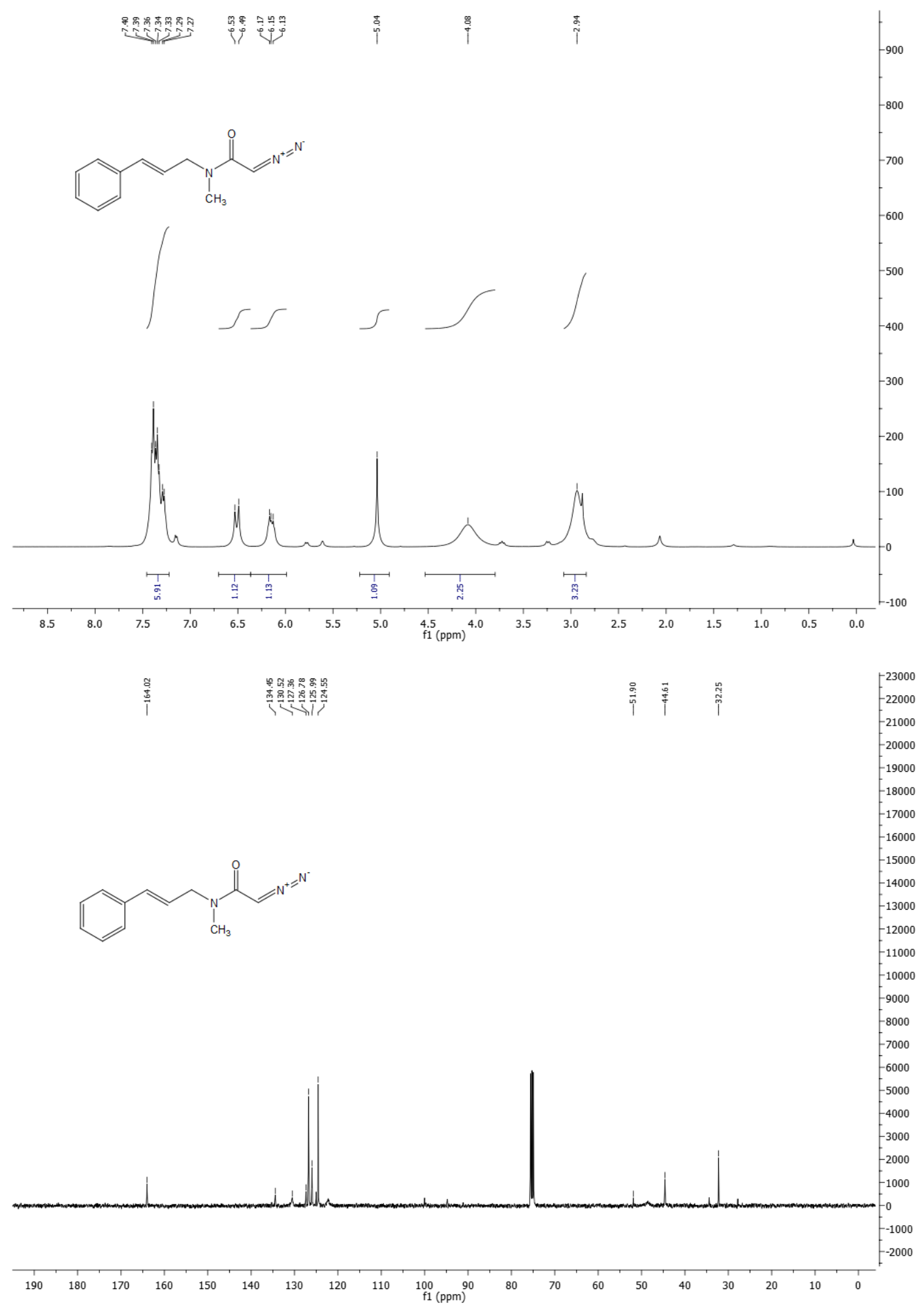


N-cinnamyl-2-diazo-N-methoxyacetamide (1c):

$500 \mathrm{MHz}{ }^{1} \mathrm{H}$ spectrum and $126 \mathrm{MHz}{ }^{13} \mathrm{C}$ spectrum in $\mathrm{CDCl}_{3}$ solvent

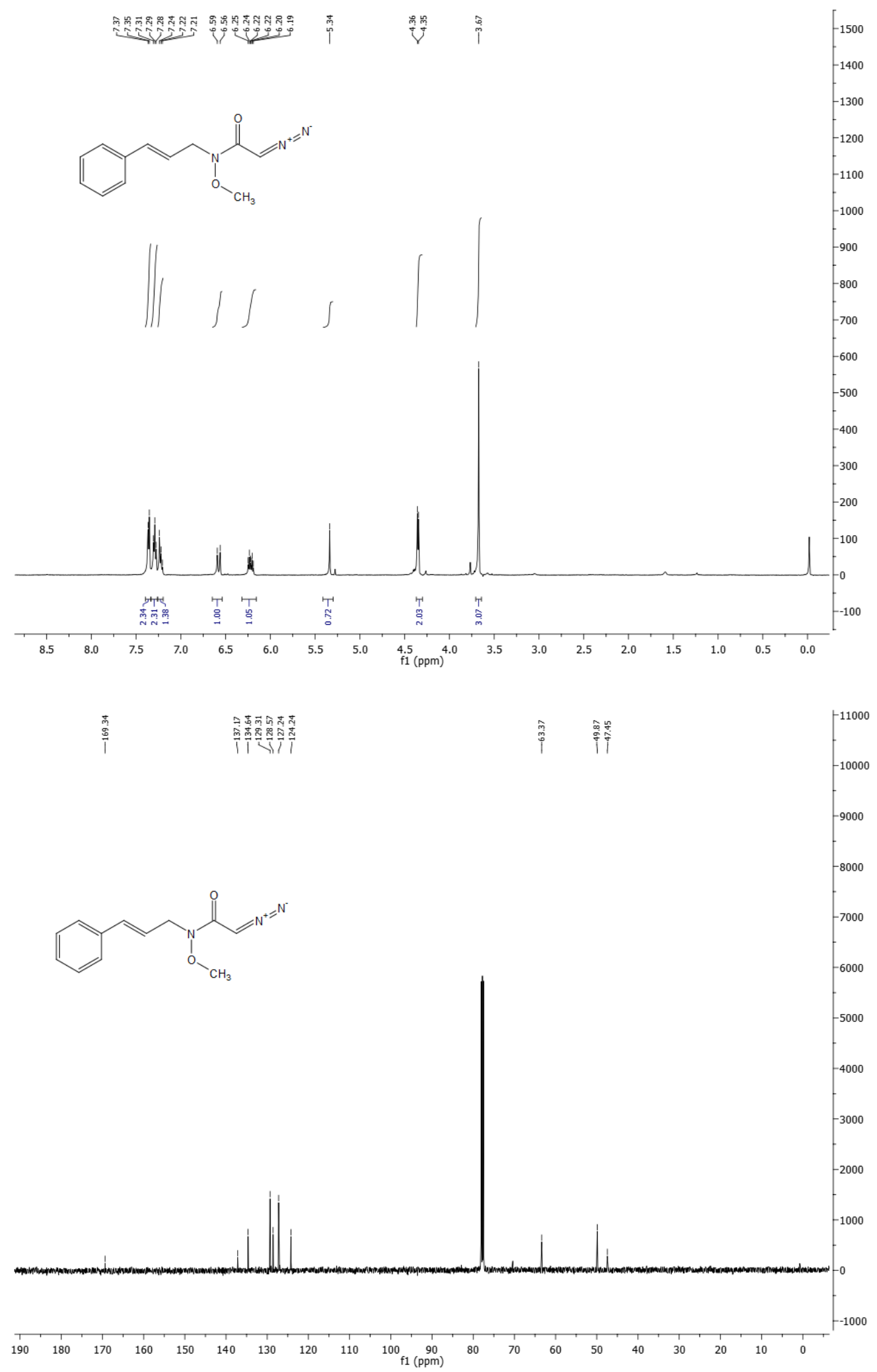


N-cinnamyl-2-diazo-N-ethylacetamide (1d): Rotamer mixture 80:20

$400 \mathrm{MHz}{ }^{1} \mathrm{H}$ spectrum and $126 \mathrm{MHz}{ }^{13} \mathrm{C}$ spectrum in $\mathrm{CDCl}_{3}$ solvent

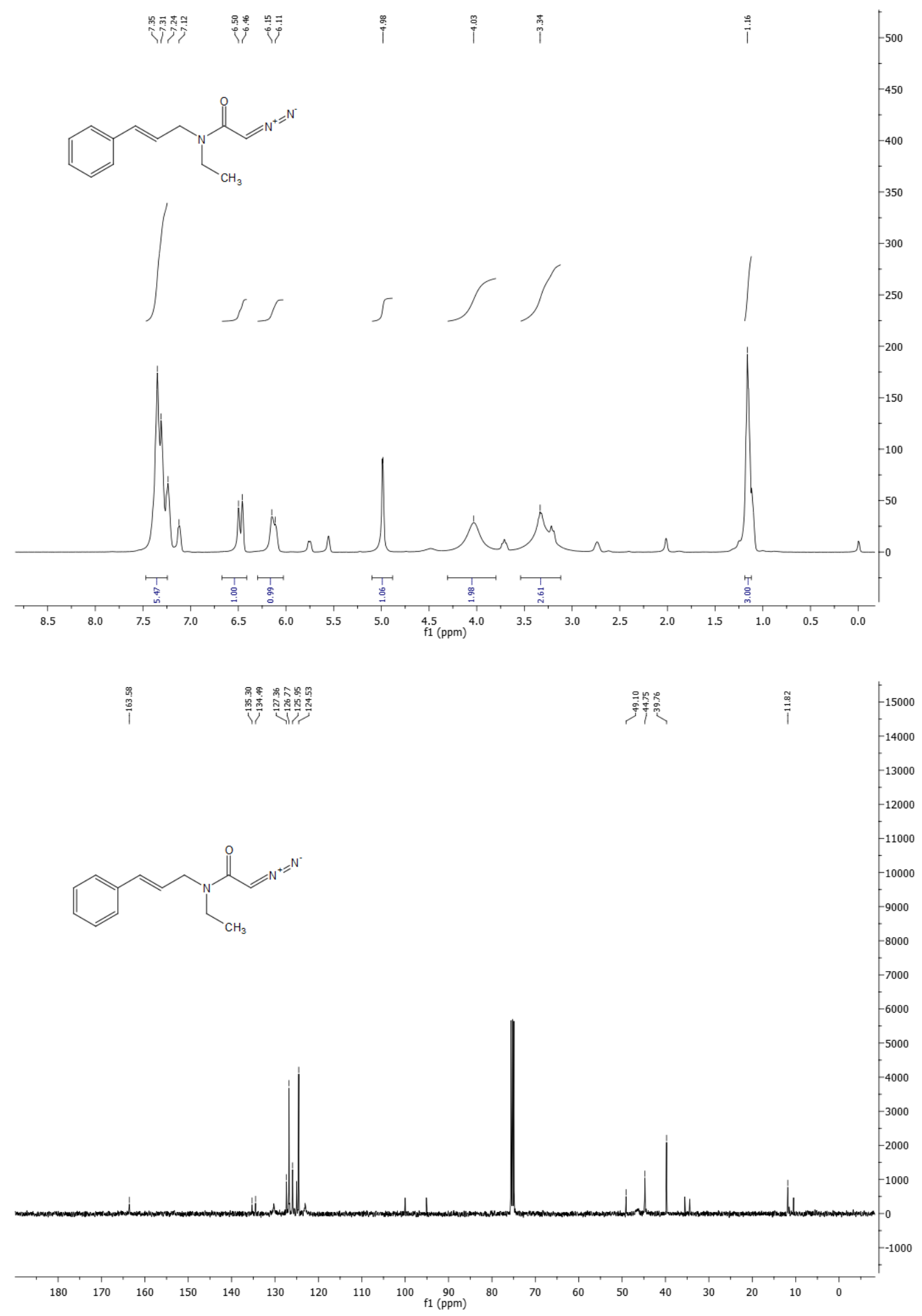


N-cinnamyl-2-diazoacetamide (1e):

$500 \mathrm{MHz}{ }^{1} \mathrm{H}$ spectrum and $126 \mathrm{MHz}{ }^{13} \mathrm{C}$ spectrum in MeOD solvent

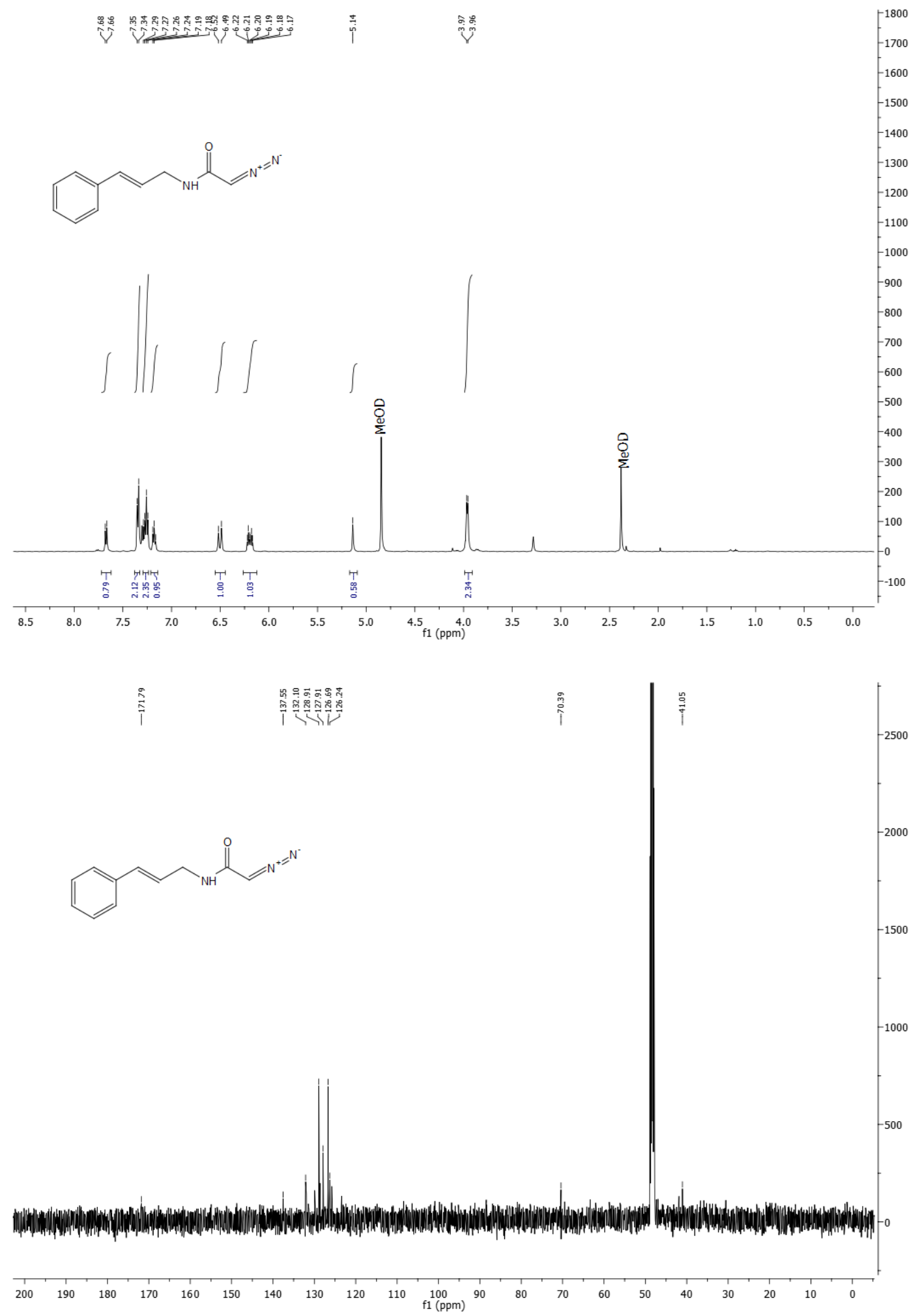


(E)-2-diazo-N-(3-(furan-2-yl)allyl)-N-methylacetamide (1f): mixture of rotamers 60:40 $500 \mathrm{MHz}{ }^{1} \mathrm{H}$ spectrum and $126 \mathrm{MHz}{ }^{13} \mathrm{C}$ spectrum in $\mathrm{CDCl}_{3}$ solvent

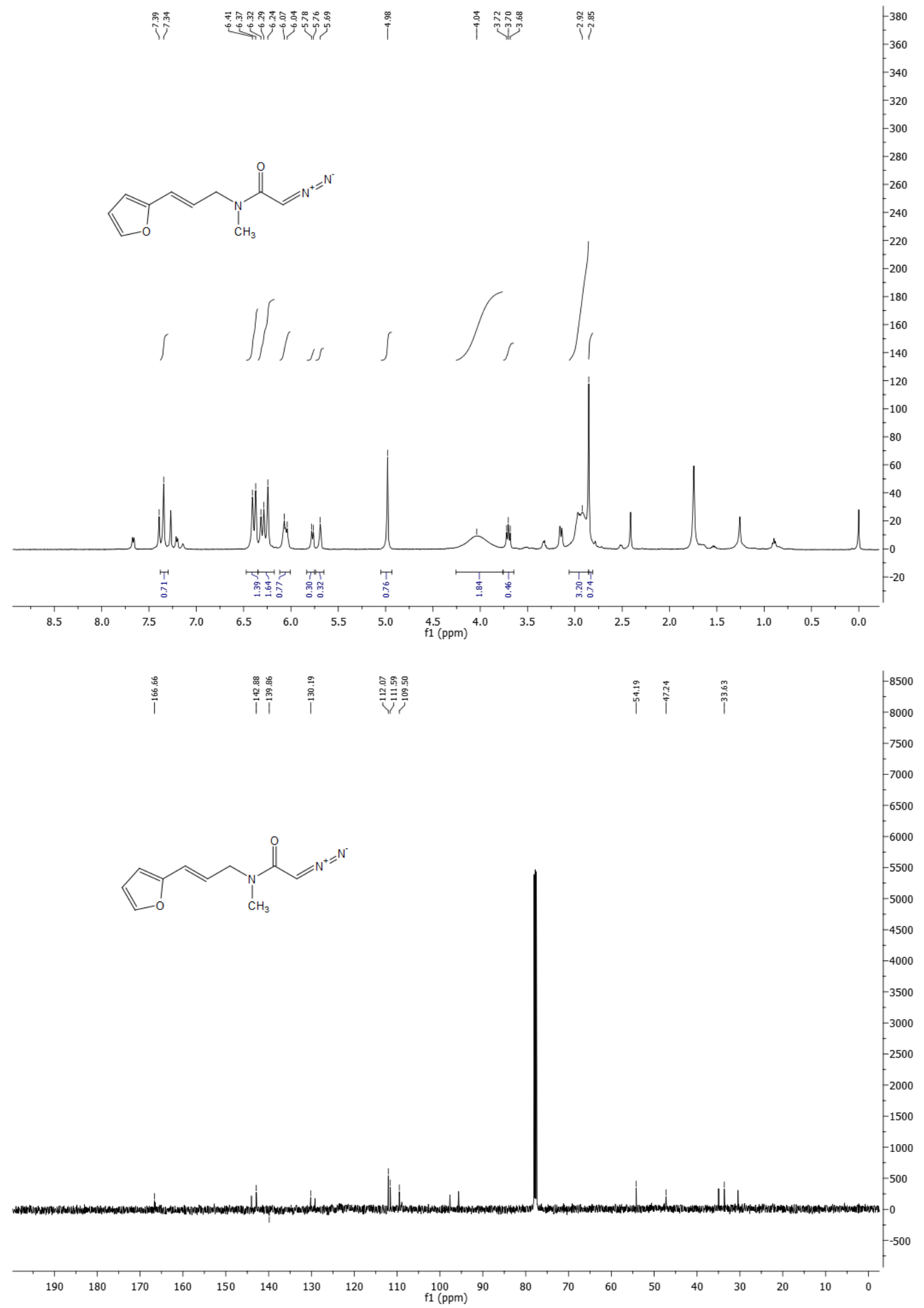


2-diazo-N-methyl-N-(3-methylbut-2-en-1-yl)acetamide (1g):

$500 \mathrm{MHz}{ }^{1} \mathrm{H}$ spectrum and $126 \mathrm{MHz}{ }^{13} \mathrm{C}$ spectrum in $\mathrm{CDCl}_{3}$ solvent

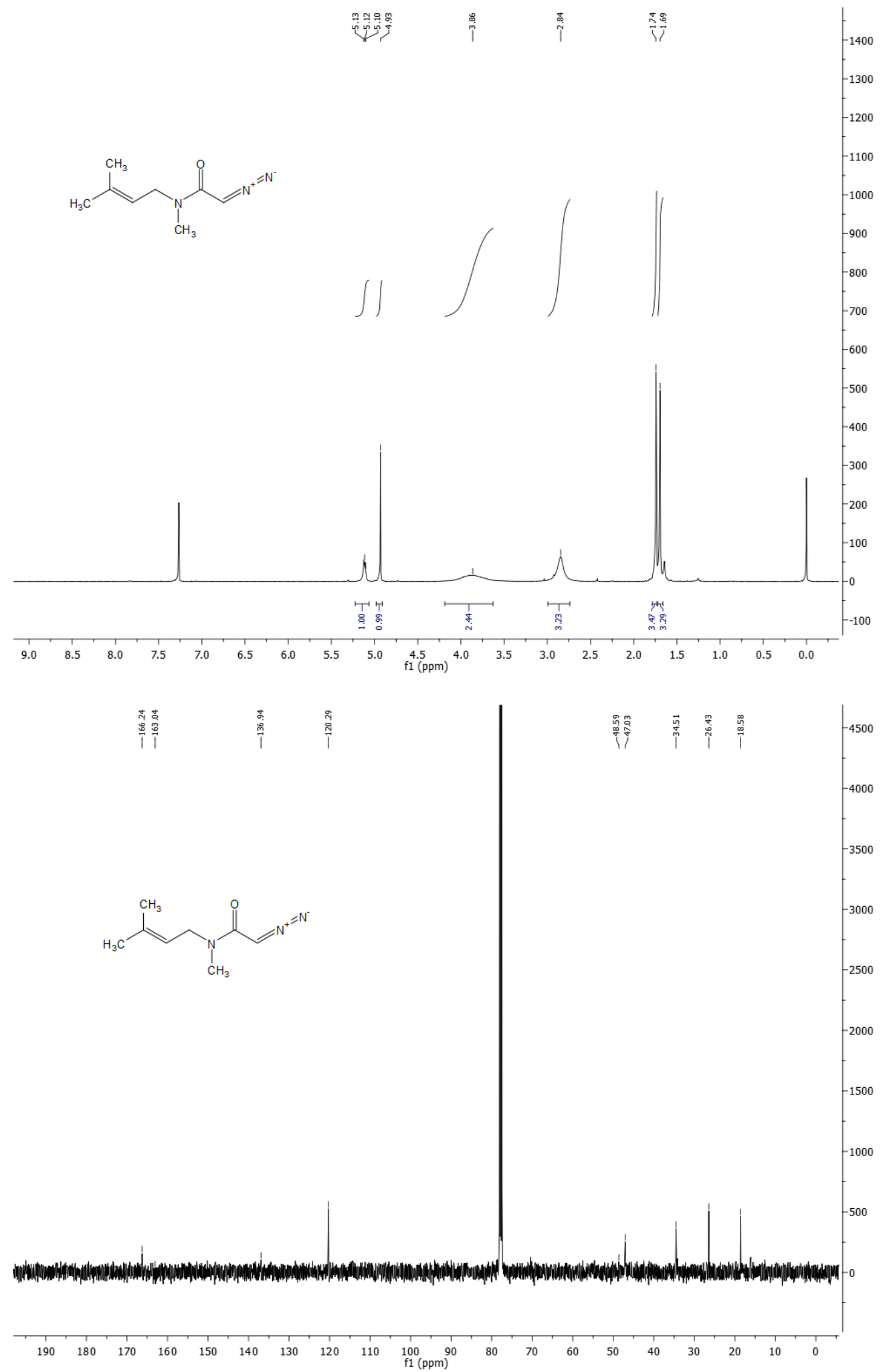


N-allyl-2-diazo-N-methylacetamide (1h): mixture of rotamers 80:20

$500 \mathrm{MHz}{ }^{1} \mathrm{H}$ spectrum and $126 \mathrm{MHz}{ }^{13} \mathrm{C}$ spectrum in $\mathrm{CDCl}_{3}$ solvent

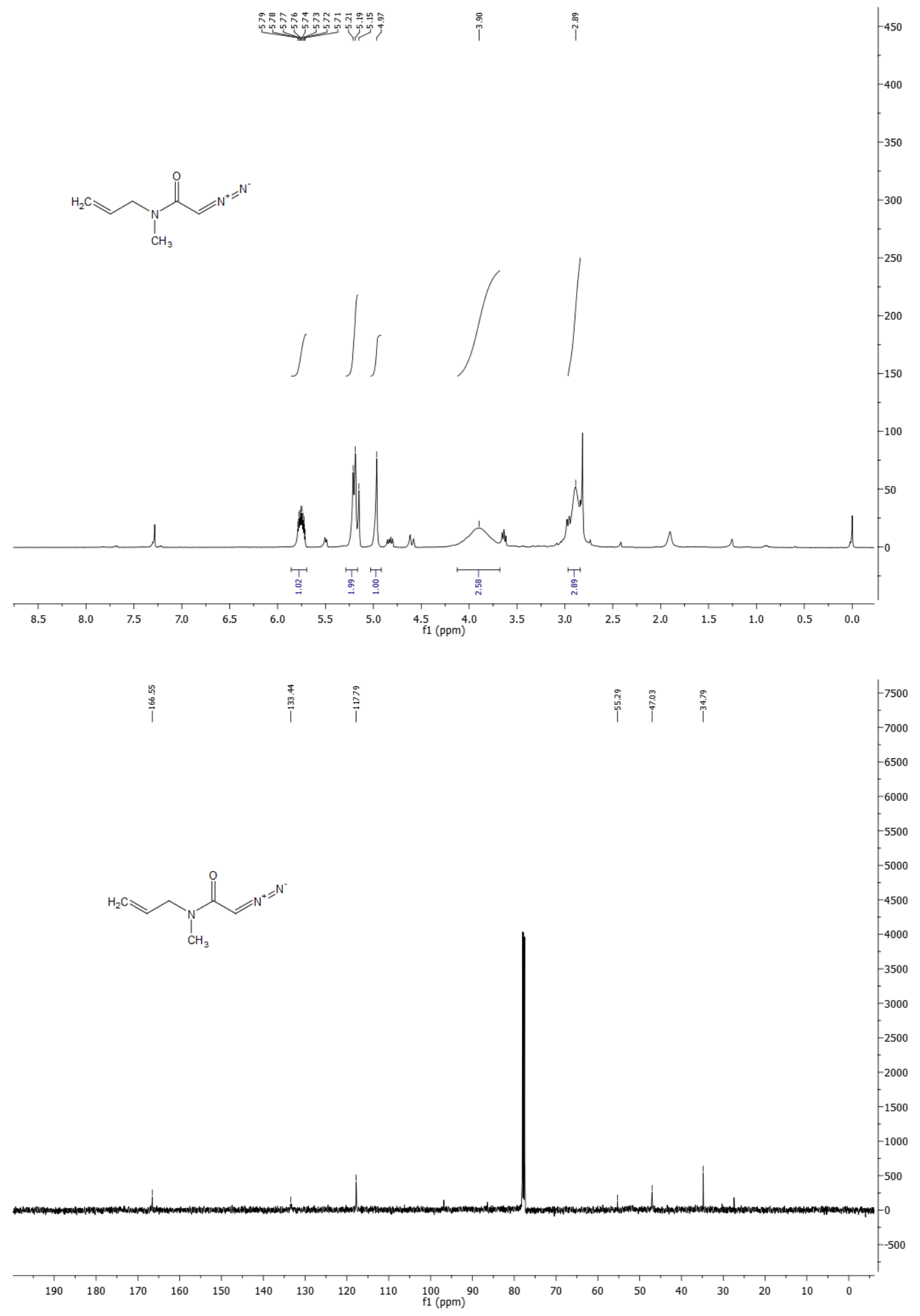


N-allyl-2-diazo-N-phenylacetamide (1i):

$500 \mathrm{MHz}{ }^{1} \mathrm{H}$ spectrum and $126 \mathrm{MHz}{ }^{13} \mathrm{C}$ spectrum in $\mathrm{CDCl}_{3}$ solvent

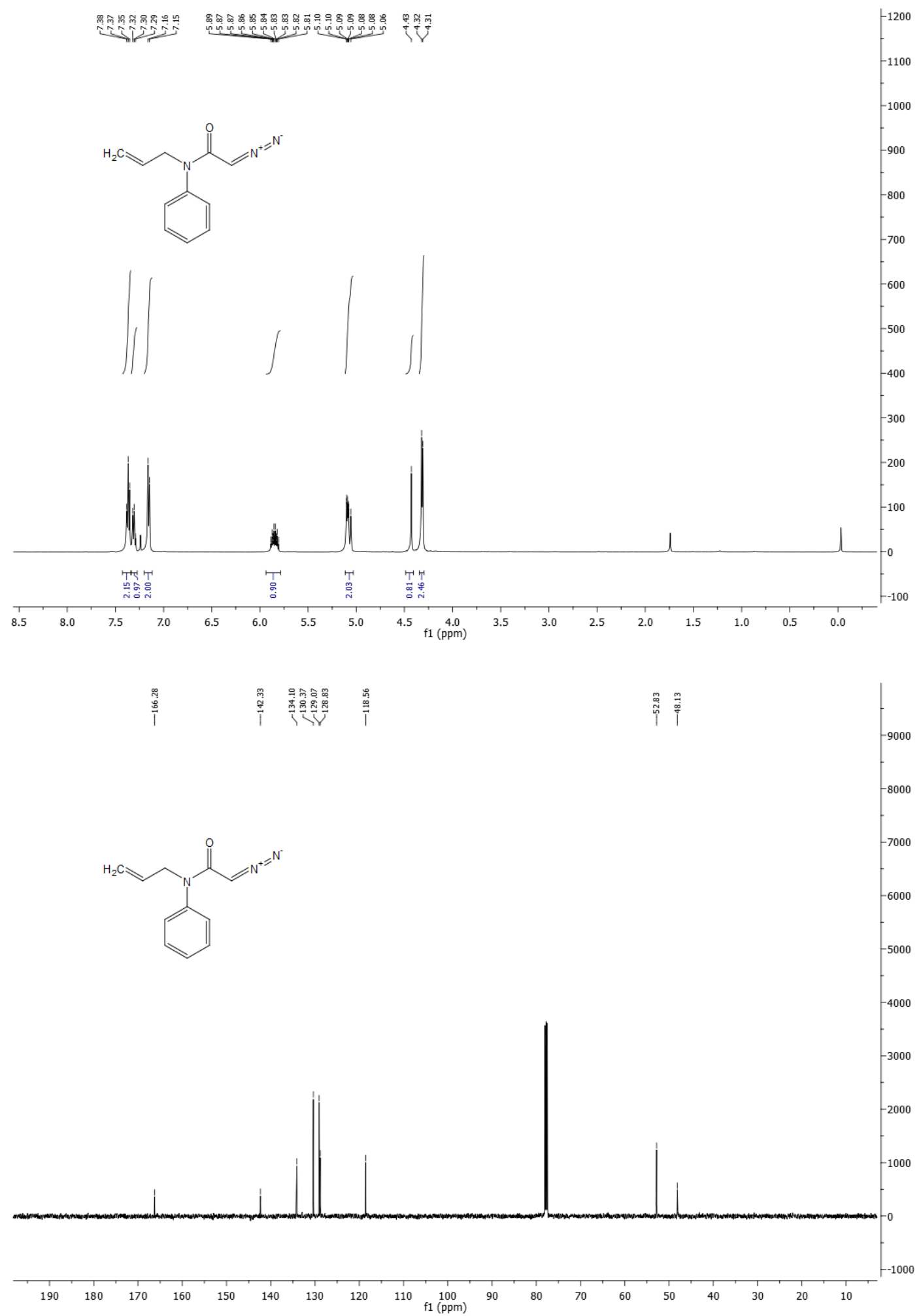


N,N-diallyl-2-diazoacetamide (1j): mixture of rotamers 85:15

$500 \mathrm{MHz}{ }^{1} \mathrm{H}$ spectrum and $126 \mathrm{MHz}{ }^{13} \mathrm{C}$ spectrum in $\mathrm{CDCl}_{3}$ solvent

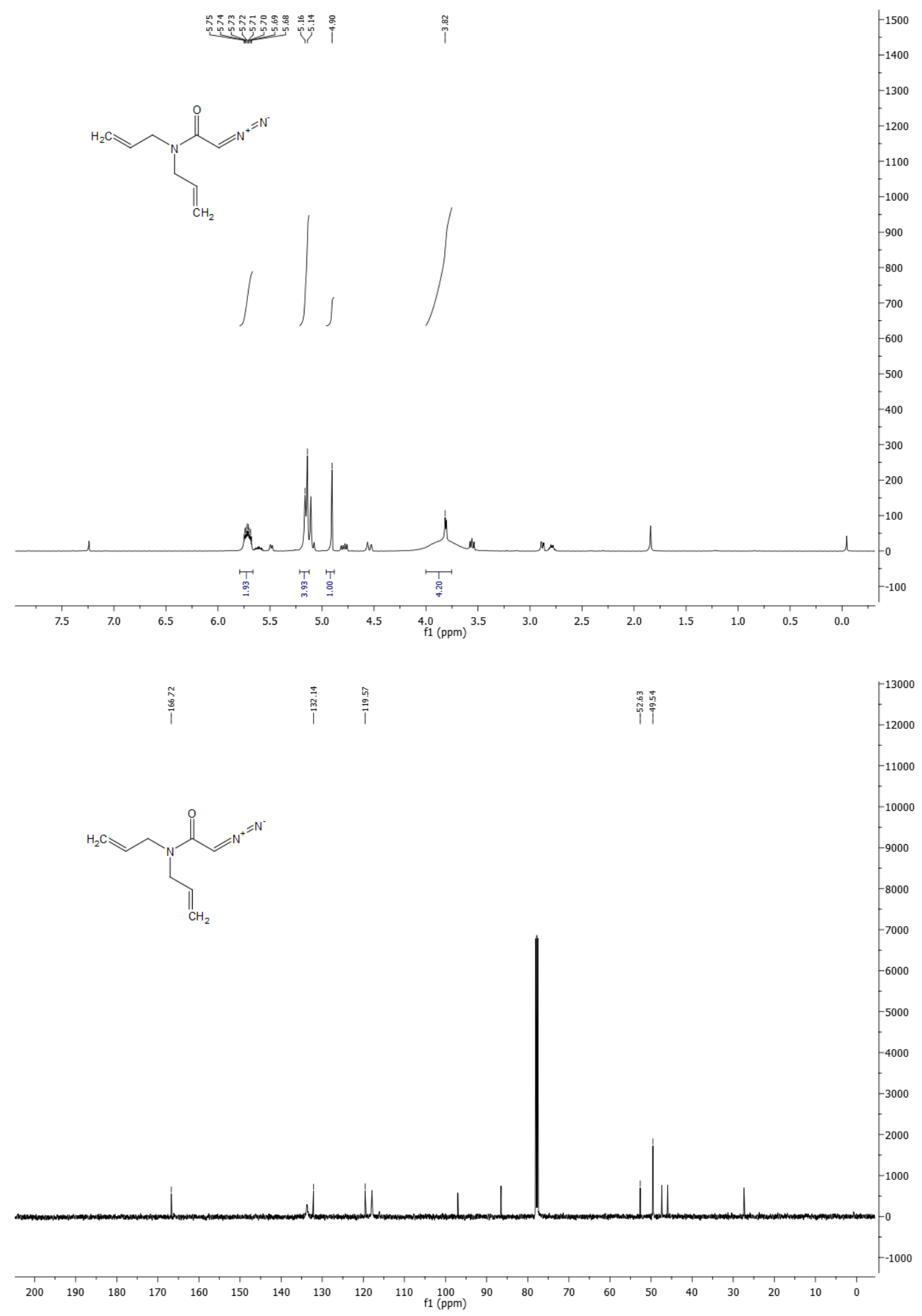


(E)-N-(3-(4-chlorophenyl)allyl)-2-diazo-N-methoxyacetamide (1k):

$500 \mathrm{MHz}{ }^{1} \mathrm{H}$ spectrum and $126 \mathrm{MHz}{ }^{13} \mathrm{C}$ spectrum in $\mathrm{CDCl}_{3}$ solvent
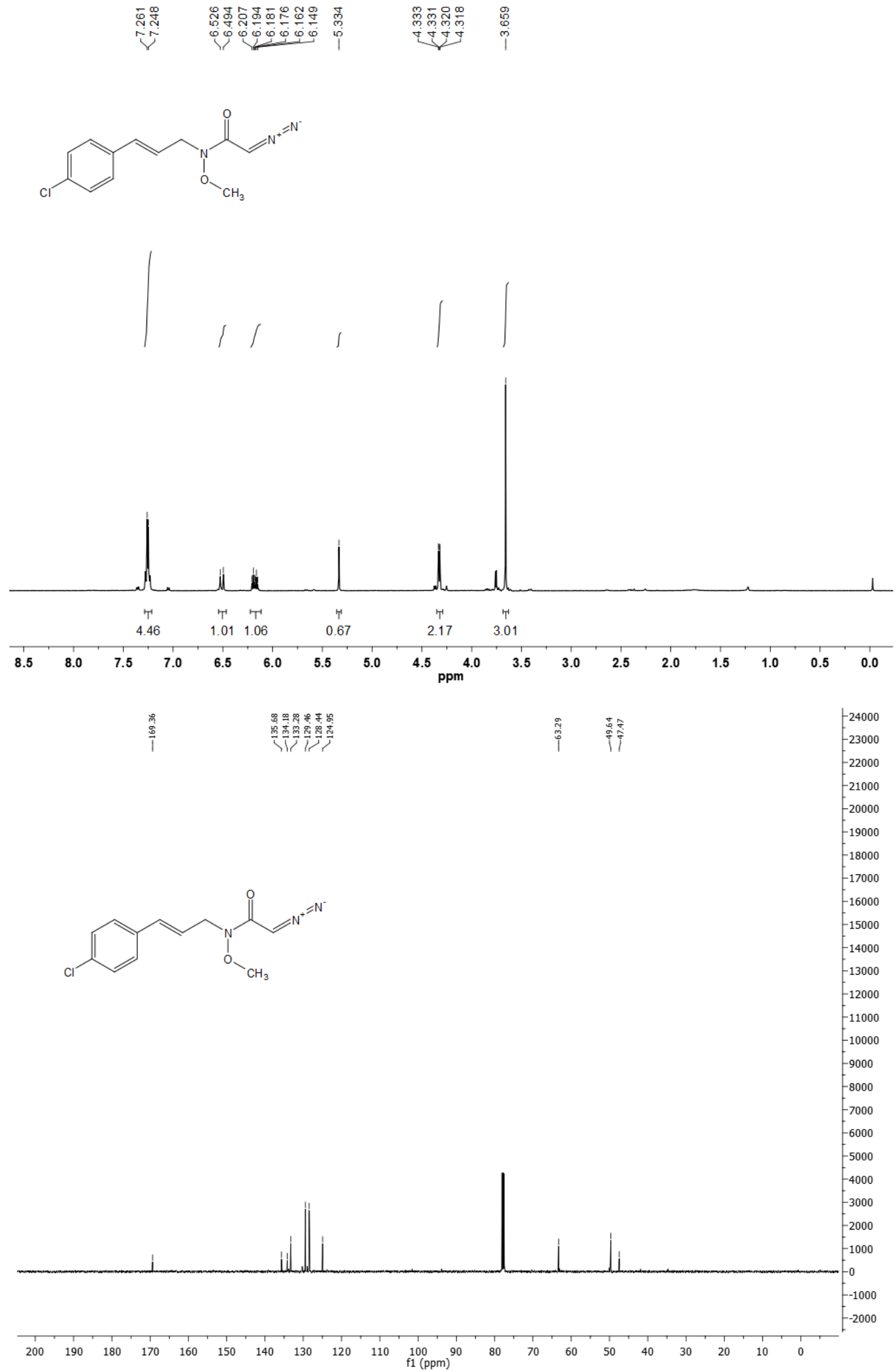
(E)-2-diazo-N-methoxy-N-(3-(4-(trifluoromethyl)phenyl)allyl)acetamide (11): $500 \mathrm{MHz}{ }^{1} \mathrm{H}$ spectrum, $126 \mathrm{MHz}{ }^{13} \mathrm{C}$ spectrum and $376 \mathrm{MHz}{ }^{19} \mathrm{~F}$ spectrum in $\mathrm{CDCl}_{3}$ solvent

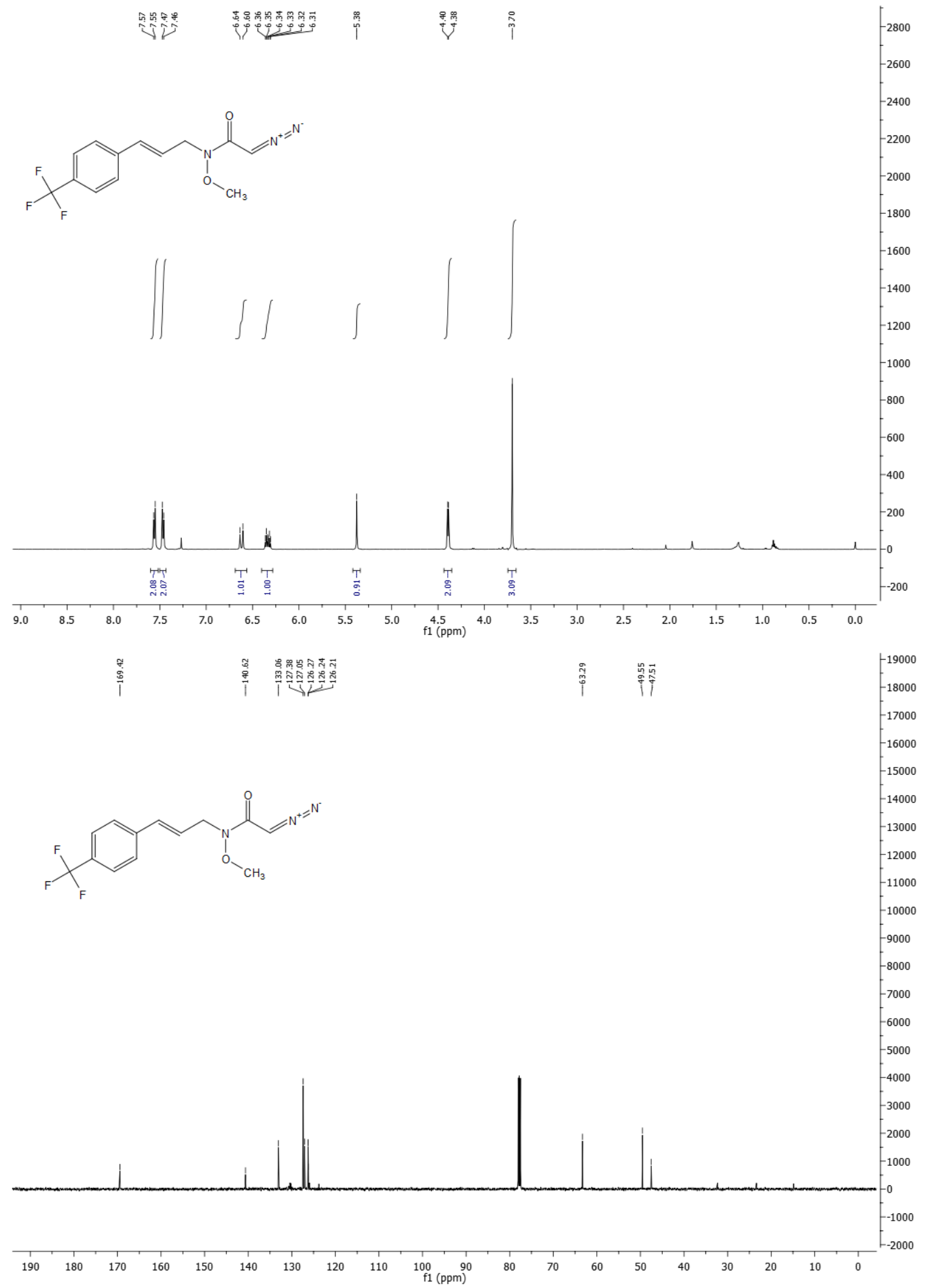




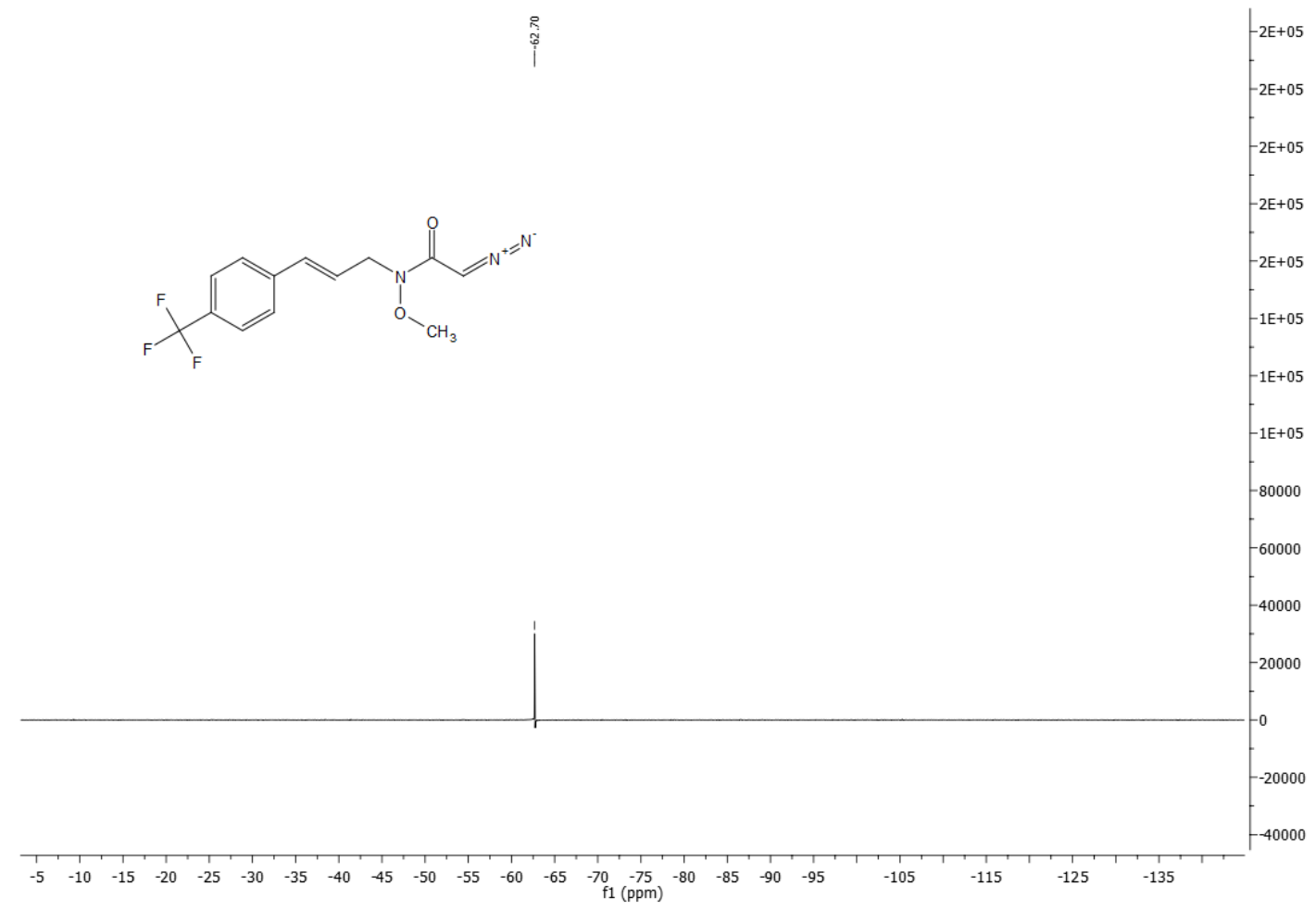


(E)-2-diazo-N-methoxy-N-(3-(3-methoxyphenyl)allyl)acetamide (1m):

$500 \mathrm{MHz}{ }^{1} \mathrm{H}$ spectrum and $126 \mathrm{MHz}{ }^{13} \mathrm{C}$ spectrum in $\mathrm{CDCl}_{3}$ solvent

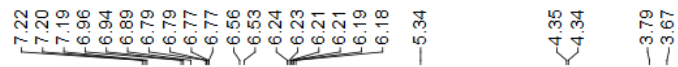<smiles>COc1cccc(/C=C/CN(OC)C(=O)C=[W])c1</smiles>

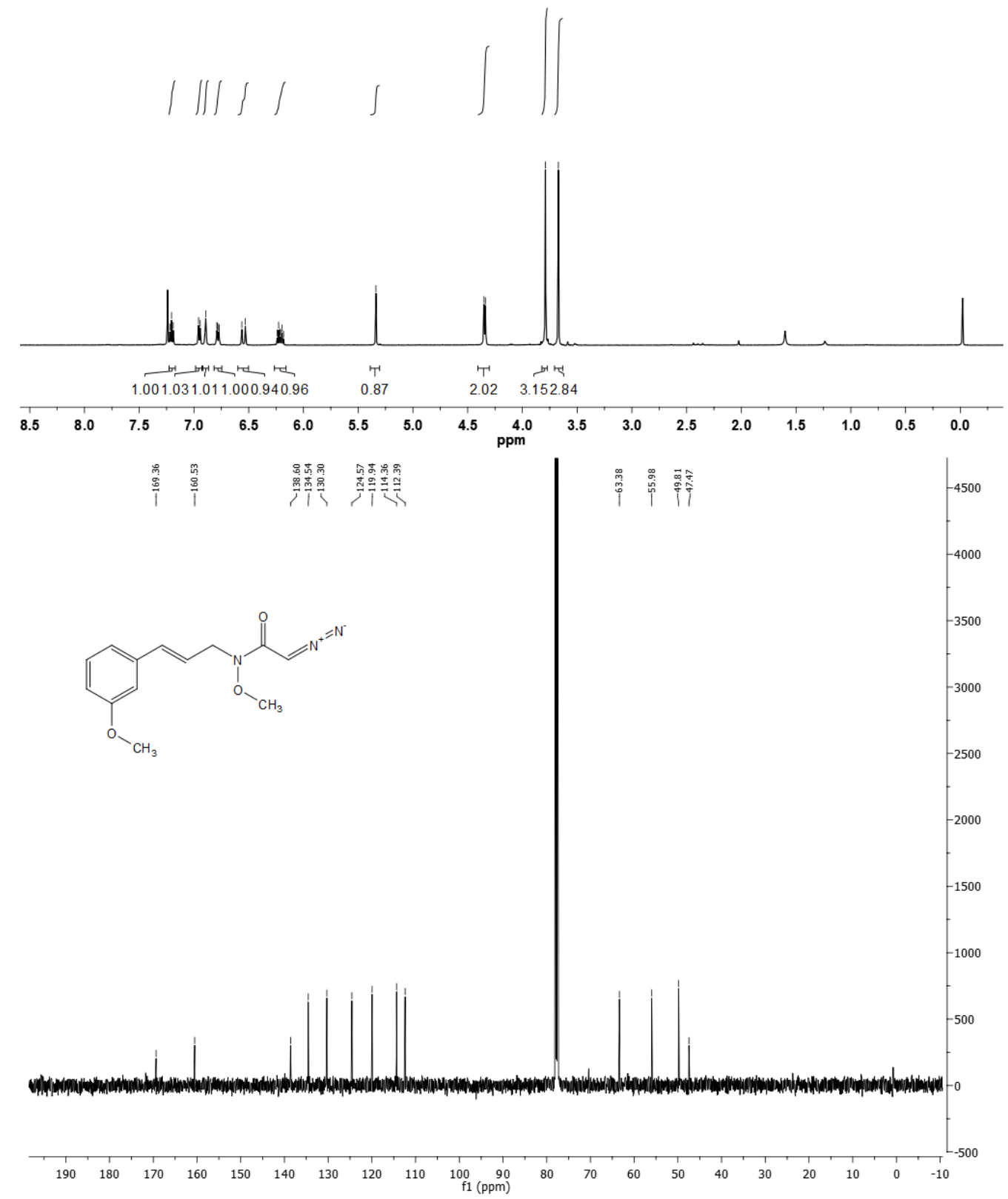


(E)-2-diazo-N-methoxy-N-(3-(o-tolyl)allyl)acetamide (1n):

$500 \mathrm{MHz}{ }^{1} \mathrm{H}$ spectrum and $126 \mathrm{MHz}{ }^{13} \mathrm{C}$ spectrum in $\mathrm{CDCl}_{3}$ solvent

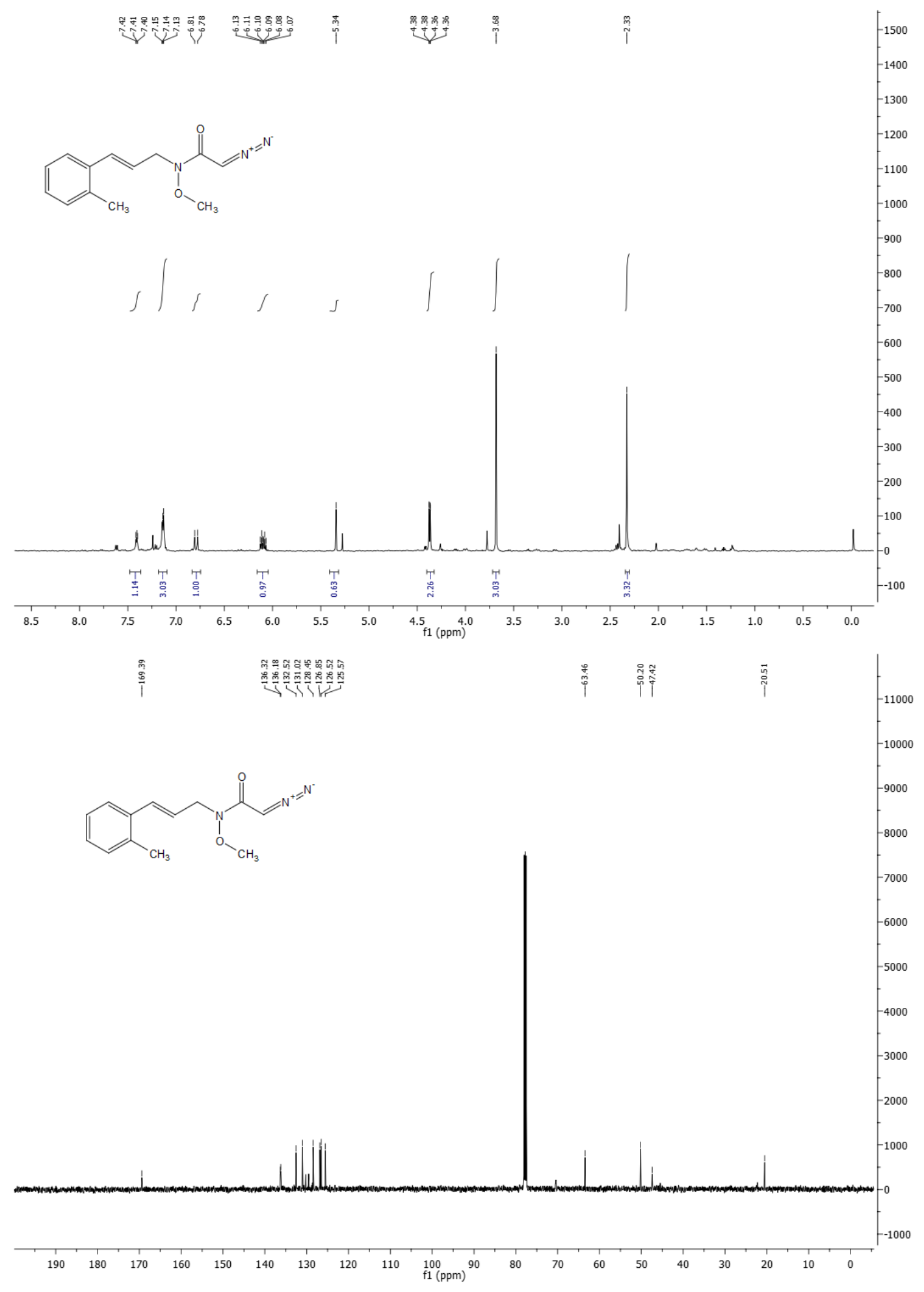


(1R,5S,6S)-6-(4-fluorophenyl)-3-methyl-3-azabicyclo[3.1.0]hexan-2-one (2a):

$500 \mathrm{MHz}{ }^{1} \mathrm{H}$ spectrum, $126 \mathrm{MHz}{ }^{13} \mathrm{C}$ spectrum and $376 \mathrm{MHz}{ }^{19} \mathrm{~F}$ spectrum in $\mathrm{CDCl}_{3}$ solvent

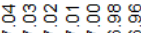

rivingen

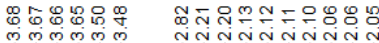
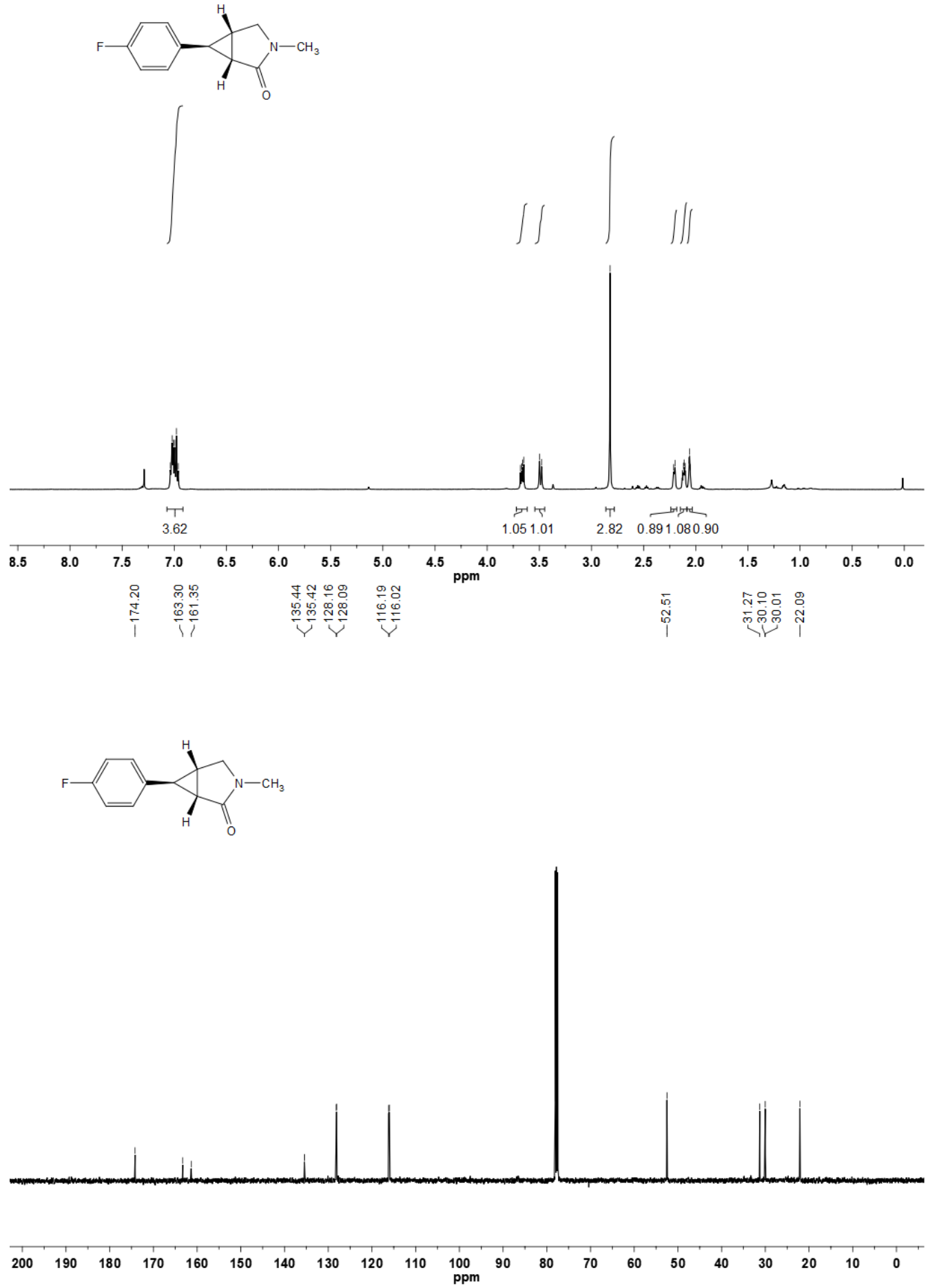


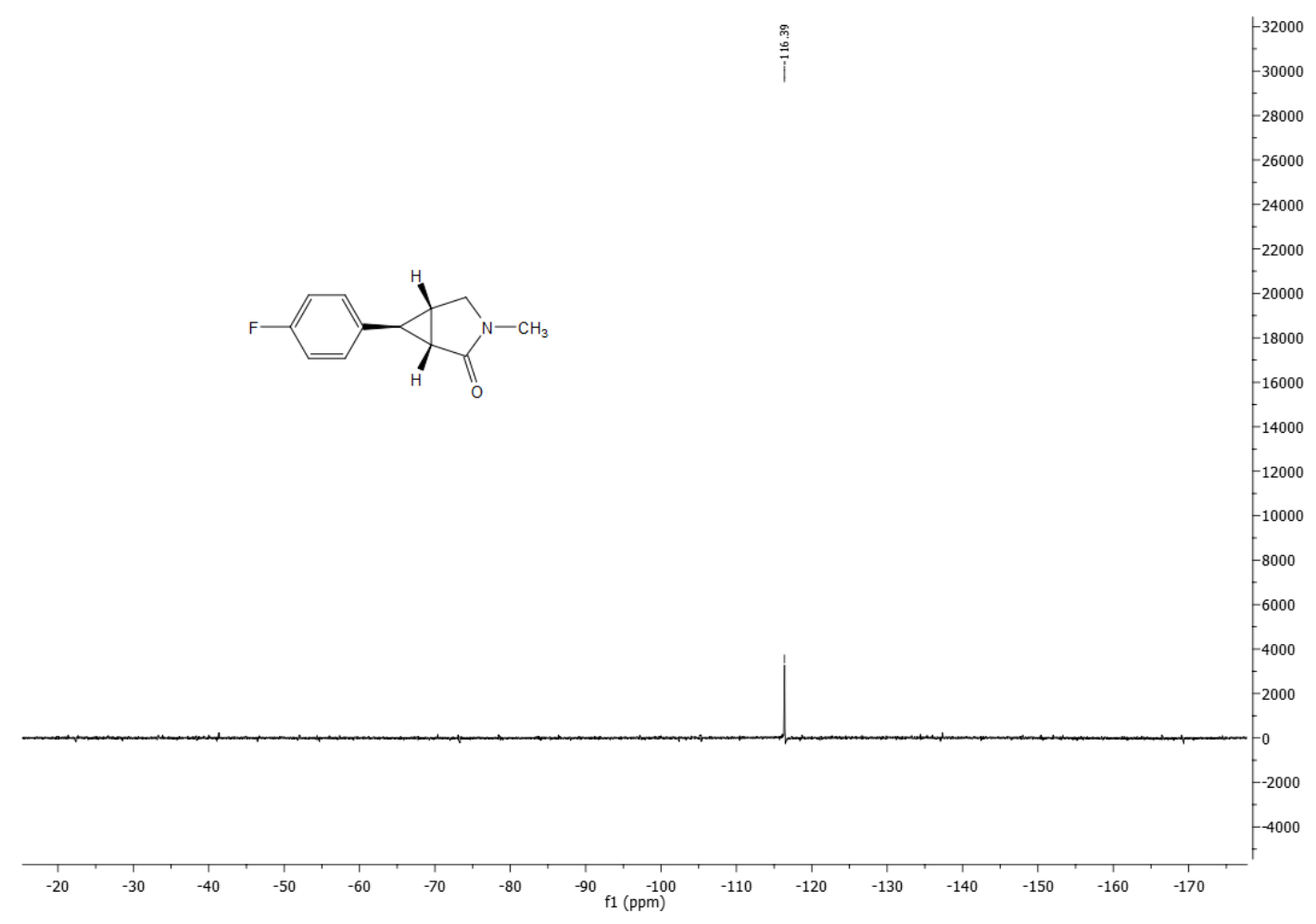


(1R,5S,6S)-3-methyl-6-phenyl-3-azabicyclo[3.1.0]hexan-2-one (2b):

$500 \mathrm{MHz}{ }^{1} \mathrm{H}$ spectrum and $126 \mathrm{MHz}{ }^{13} \mathrm{C}$ spectrum in $\mathrm{CDCl}_{3}$ solvent

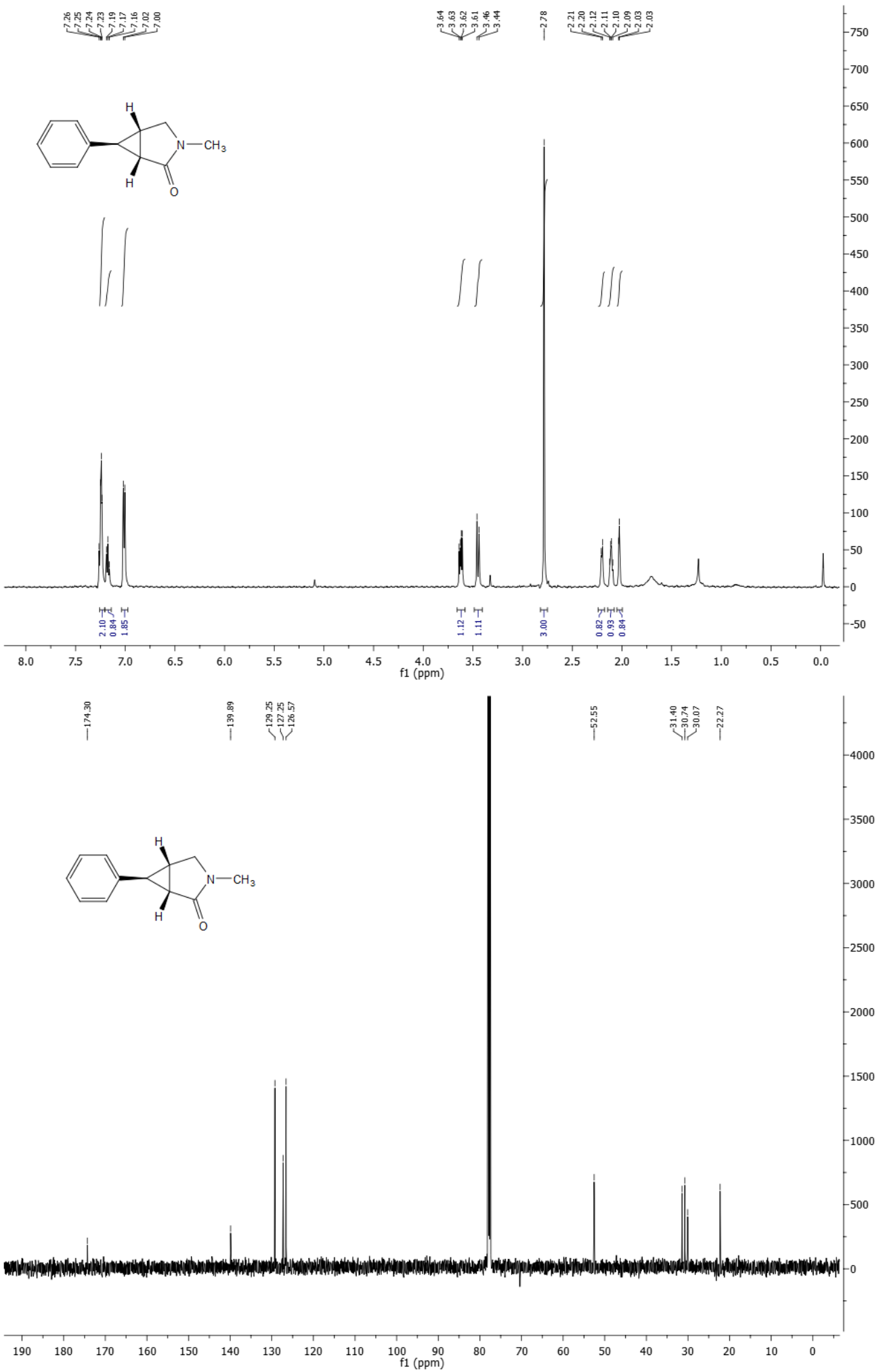


(1R,5S,6S)-3-methoxy-6-phenyl-3-azabicyclo[3.1.0]hexan-2-one (2c): $500 \mathrm{MHz}{ }^{1} \mathrm{H}$ spectrum and $126 \mathrm{MHz}{ }^{13} \mathrm{C}$ spectrum in $\mathrm{CDCl}_{3}$ solvent

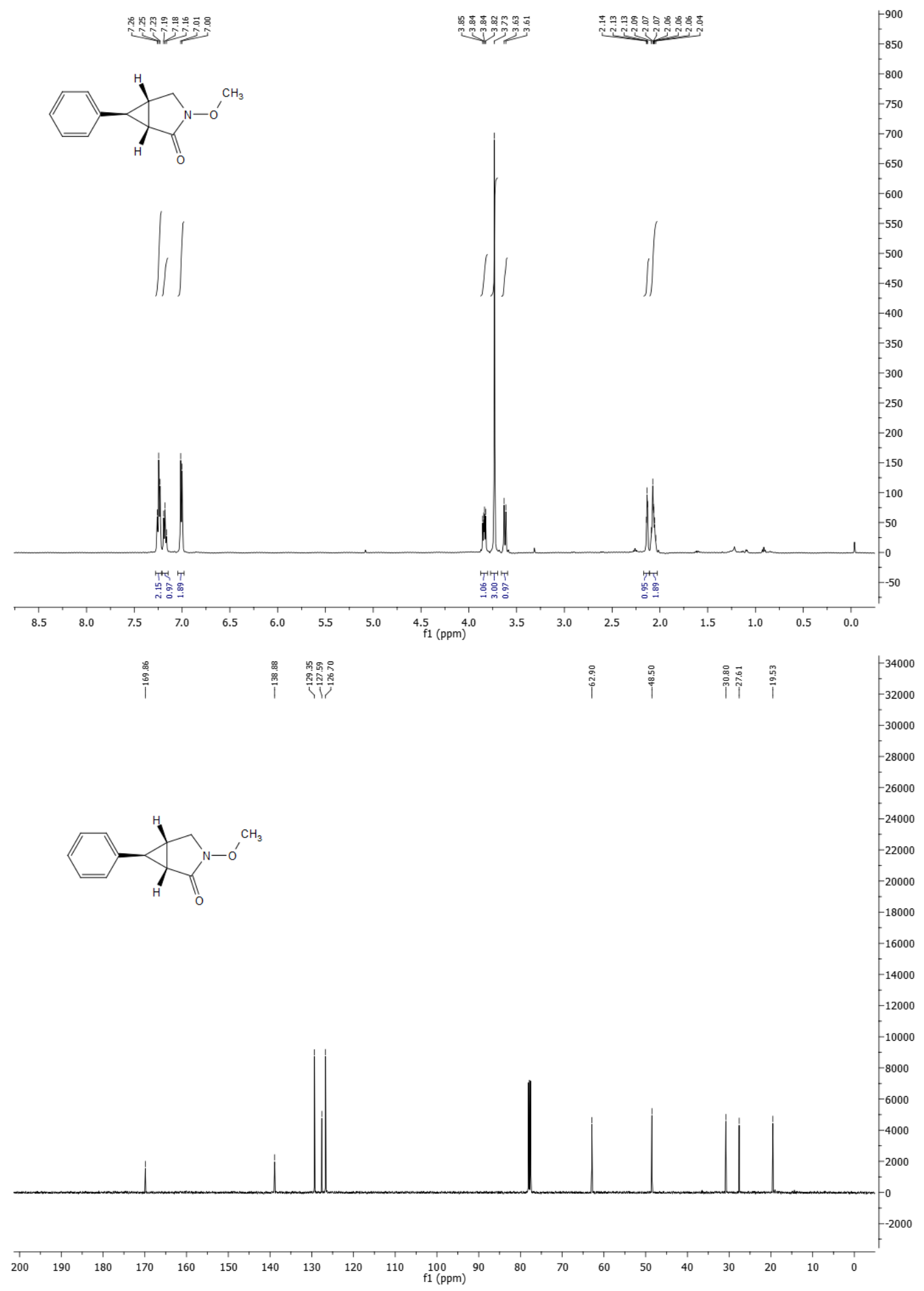


(1R,5S,6S)-3-ethyl-6-phenyl-3-azabicyclo[3.1.0]hexan-2-one (2d):

$500 \mathrm{MHz}{ }^{1} \mathrm{H}$ spectrum and $126 \mathrm{MHz}{ }^{13} \mathrm{C}$ spectrum in $\mathrm{CDCl}_{3}$ solvent

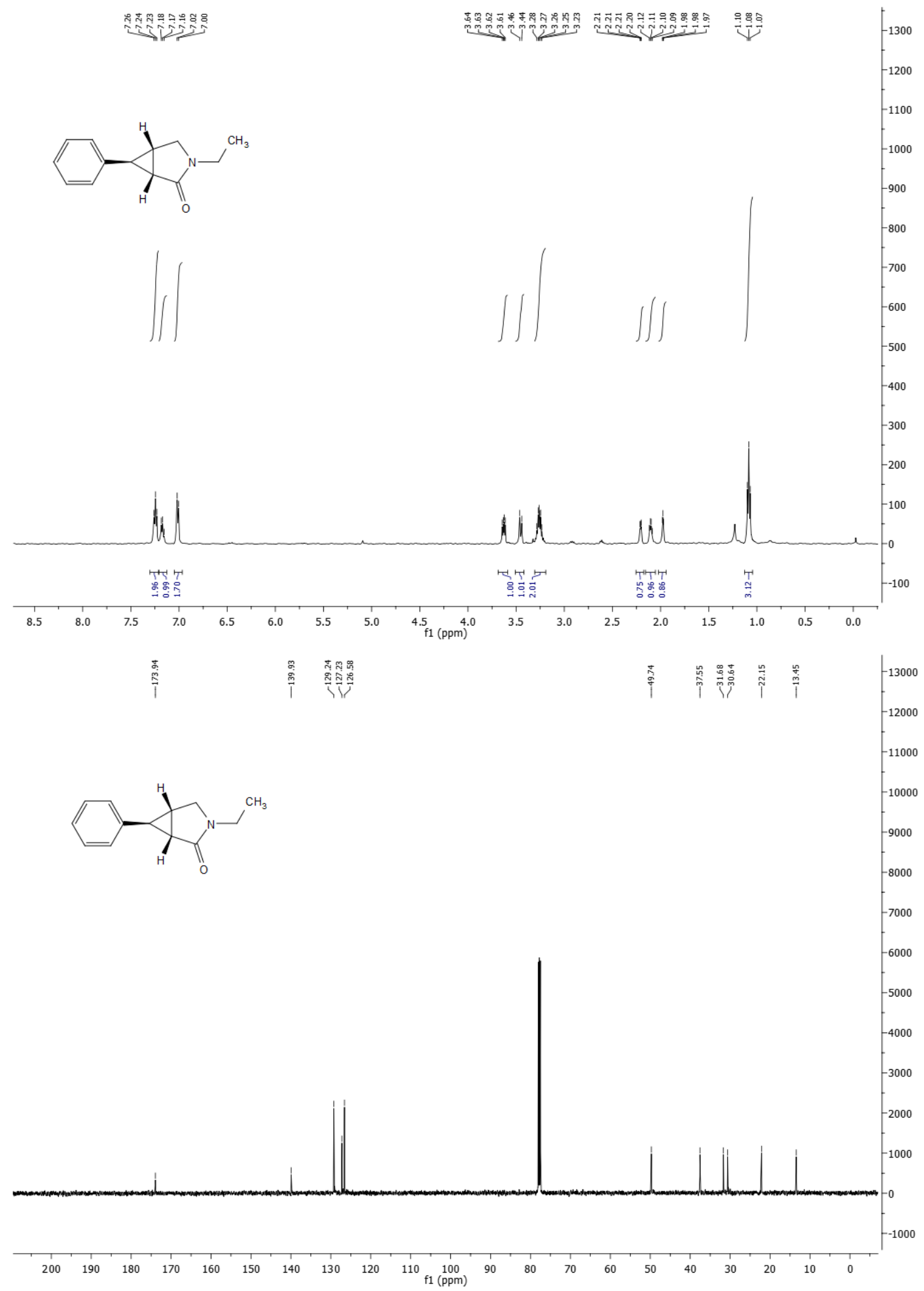


(1R,5S,6S)-6-phenyl-3-azabicyclo[3.1.0]hexan-2-one (2e):

$500 \mathrm{MHz}{ }^{1} \mathrm{H}$ spectrum and $126 \mathrm{MHz}{ }^{13} \mathrm{C}$ spectrum in $\mathrm{CDCl}_{3}$ solvent

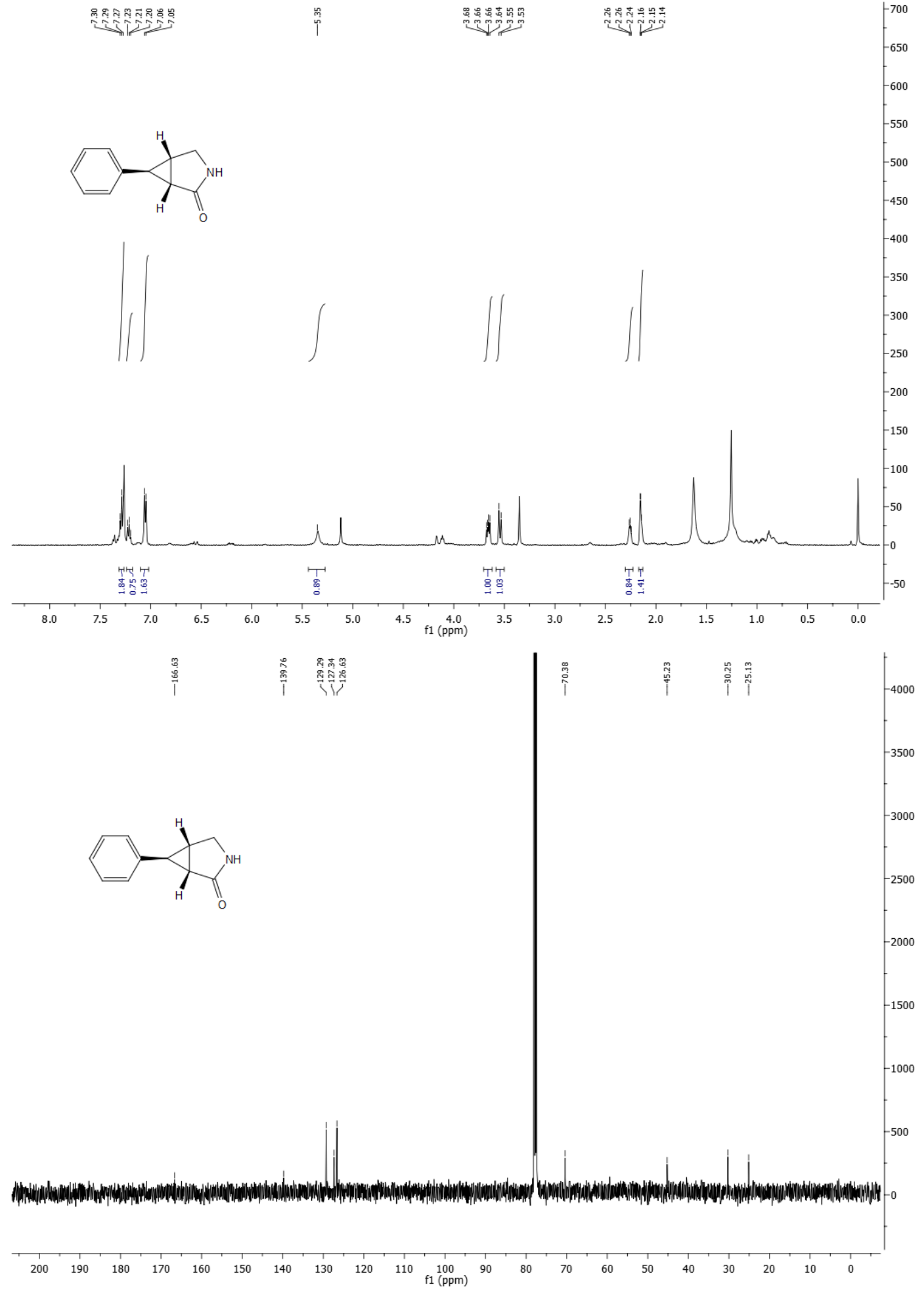


(1R,5S,6S)-6-(furan-2-yl)-3-methyl-3-azabicyclo[3.1.0]hexan-2-one (2f):

$500 \mathrm{MHz}{ }^{1} \mathrm{H}$ spectrum and $126 \mathrm{MHz}^{13} \mathrm{C}$ spectrum in $\mathrm{CDCl}_{3}$ solvent
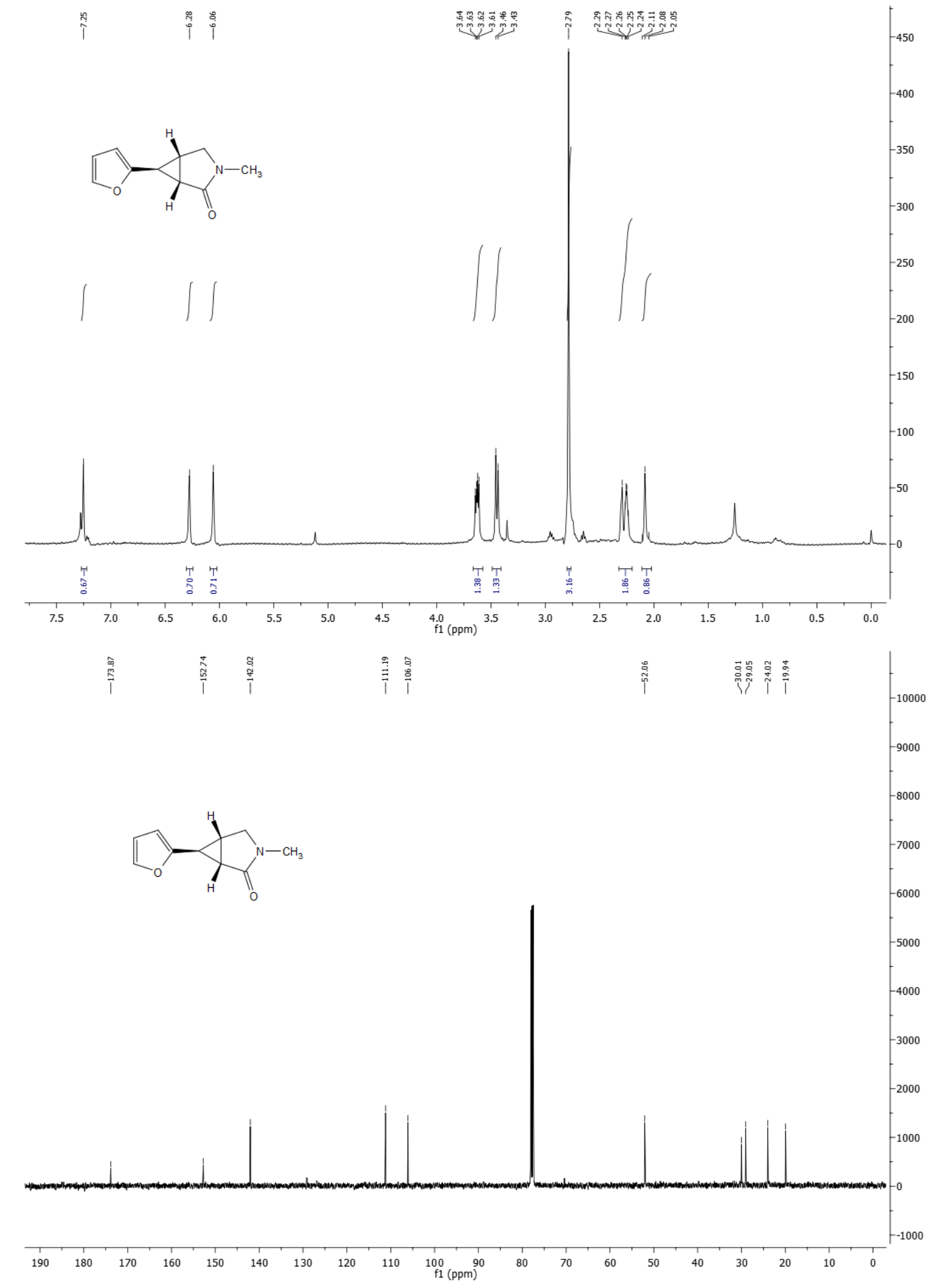
(1S,5R)-3,6,6-trimethyl-3-azabicyclo[3.1.0] hexan-2-one (2g):

$500 \mathrm{MHz}{ }^{1} \mathrm{H}$ spectrum and $126 \mathrm{MHz}{ }^{13} \mathrm{C}$ spectrum in $\mathrm{CDCl}_{3}$ solvent<smiles>C[C@@H]1[C@@H]2C(=O)N(C)C[C@H]1[C@H]2C</smiles>
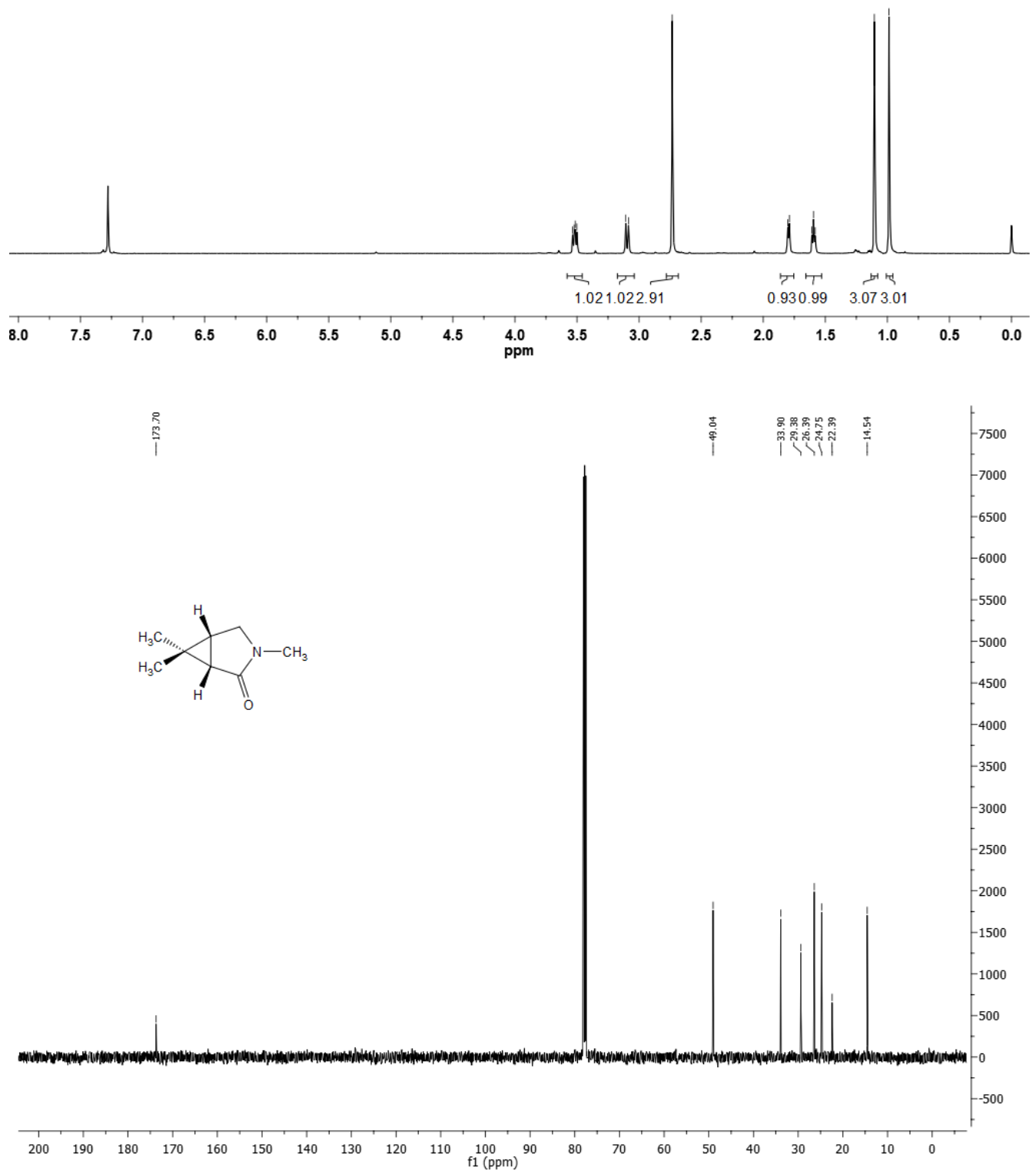
(1R,5S)-3-methyl-3-azabicyclo[3.1.0]hexan-2-one (2h):

$500 \mathrm{MHz}{ }^{1} \mathrm{H}$ spectrum and $126 \mathrm{MHz}{ }^{13} \mathrm{C}$ spectrum in $\mathrm{CDCl}_{3}$ solvent

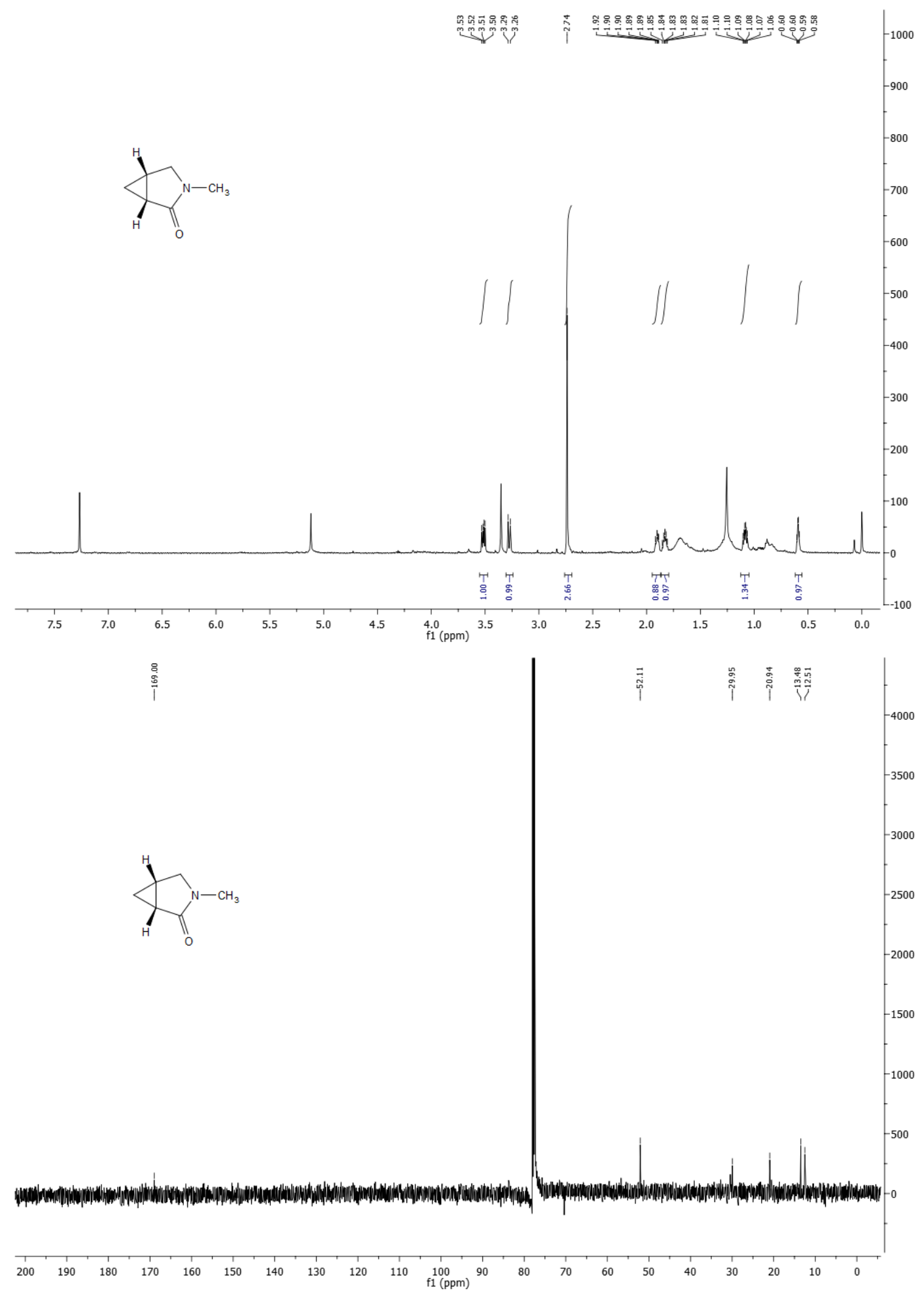


(1R,5S)-3-phenyl-3-azabicyclo[3.1.0]hexan-2-one (2i):

$500 \mathrm{MHz}{ }^{1} \mathrm{H}$ spectrum and $126 \mathrm{MHz}{ }^{13} \mathrm{C}$ spectrum in $\mathrm{CDCl}_{3}$ solvent

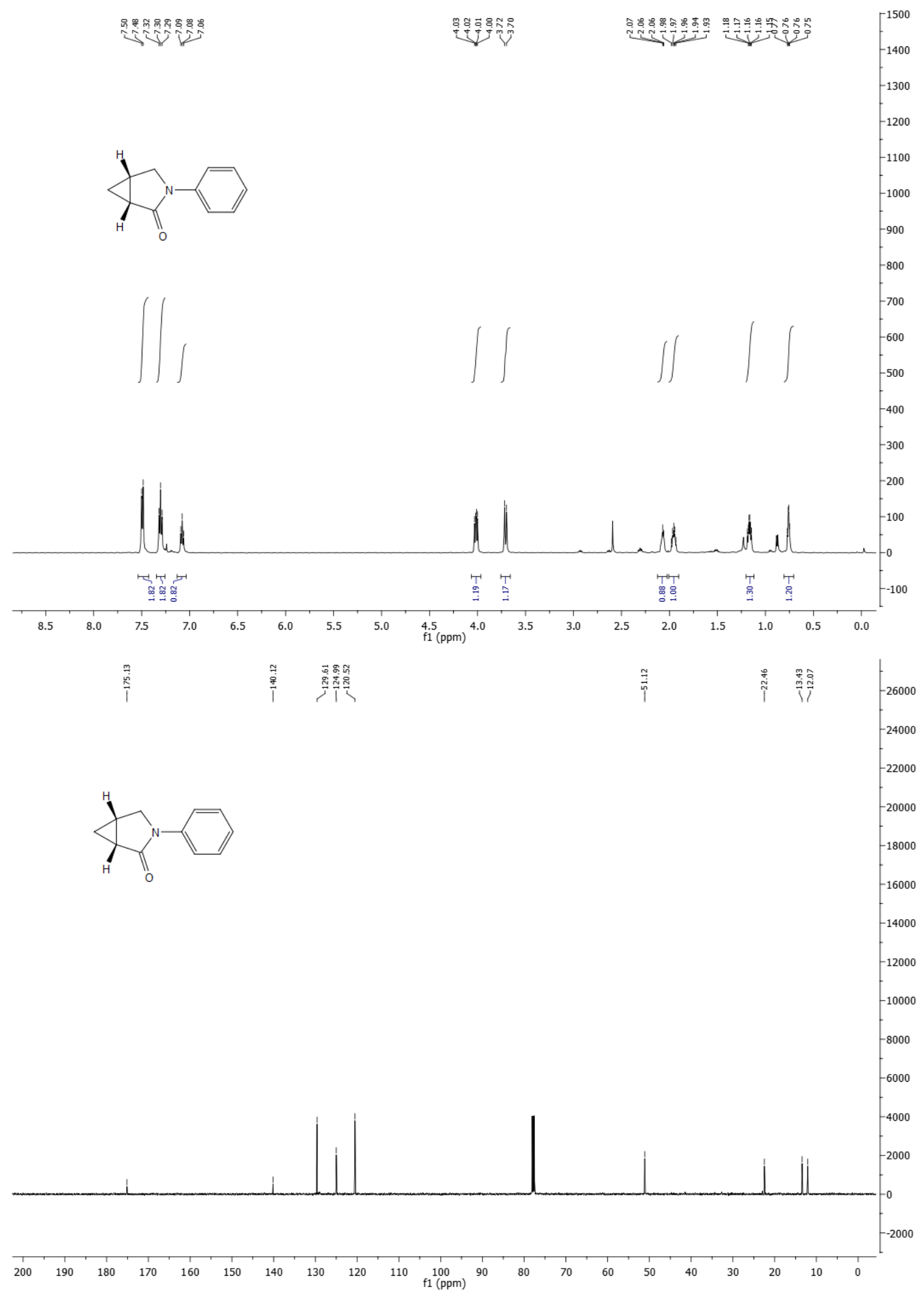


(1R,5S)-3-allyl-3-azabicyclo[3.1.0]hexan-2-one (2j):

$500 \mathrm{MHz}{ }^{1} \mathrm{H}$ spectrum and $126 \mathrm{MHz}{ }^{13} \mathrm{C}$ spectrum in $\mathrm{CDCl}_{3}$ solvent

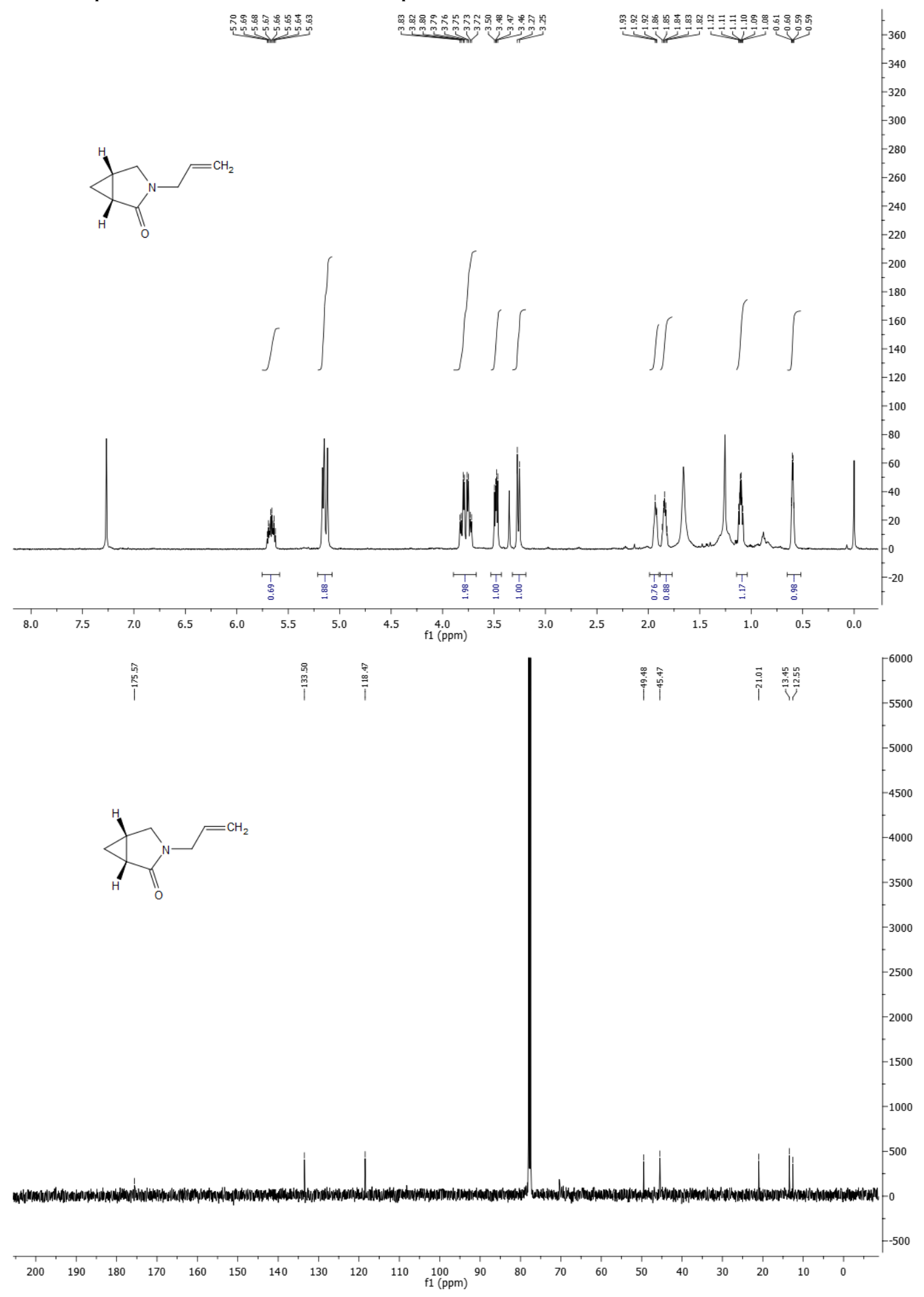


(1R,5S,6S)-6-(4-chlorophenyl)-3-methoxy-3-azabicyclo[3.1.0]hexan-2-one (2k): $500 \mathrm{MHz}{ }^{1} \mathrm{H}$ spectrum and $126 \mathrm{MHz}{ }^{13} \mathrm{C}$ spectrum in $\mathrm{CDCl}_{3}$ solvent

就最哭

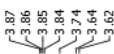

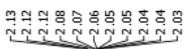

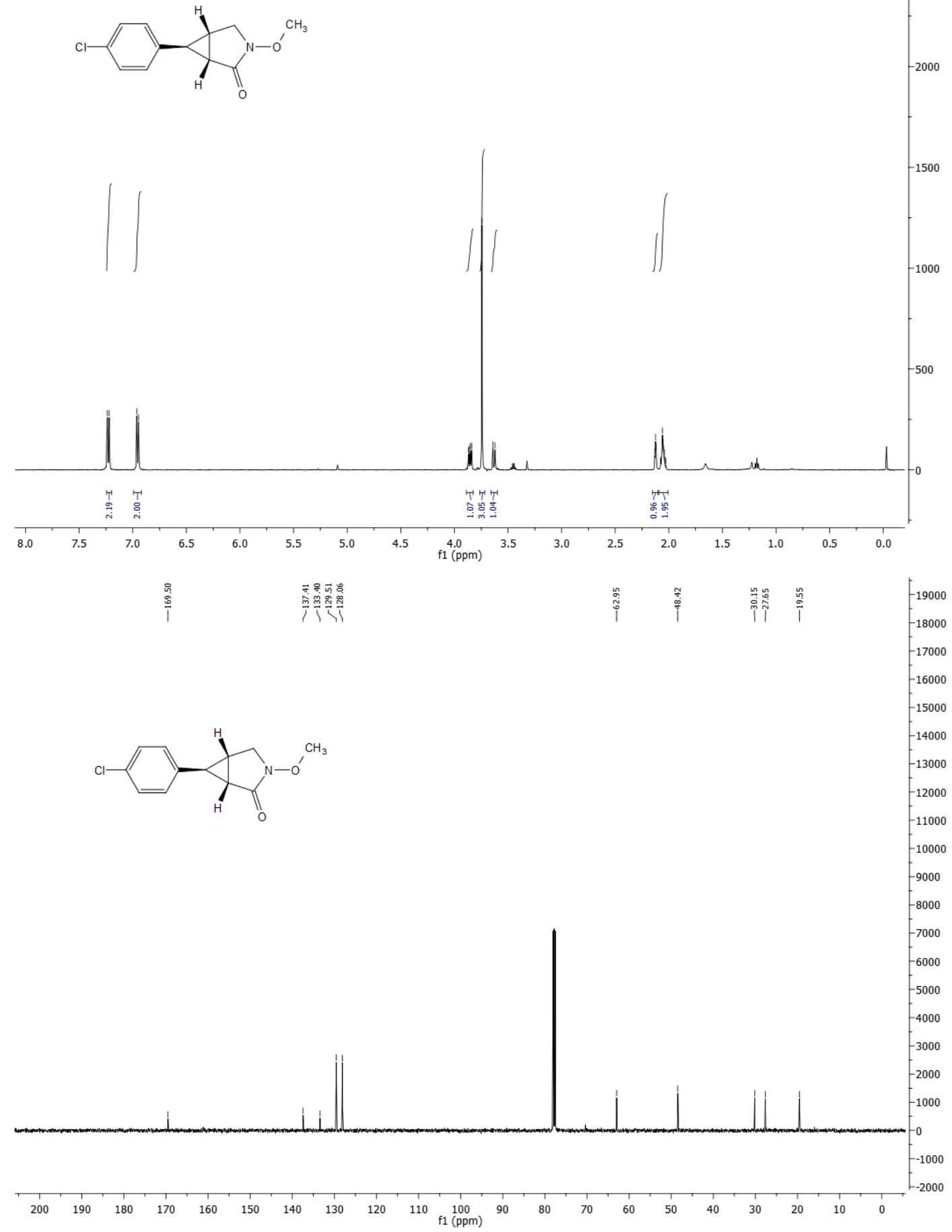

$\rightarrow$ 
(1R,5S,6S)-3-methoxy-6-(4-(trifluoromethyl)phenyl)-3-azabicyclo[3.1.0]hexan-2-one (2I): $500 \mathrm{MHz}{ }^{1} \mathrm{H}$ spectrum, $126 \mathrm{MHz}{ }^{13} \mathrm{C}$ spectrum and $376 \mathrm{MHz}{ }^{19} \mathrm{~F}$ spectrum in $\mathrm{CDCl}_{3}$ solvent
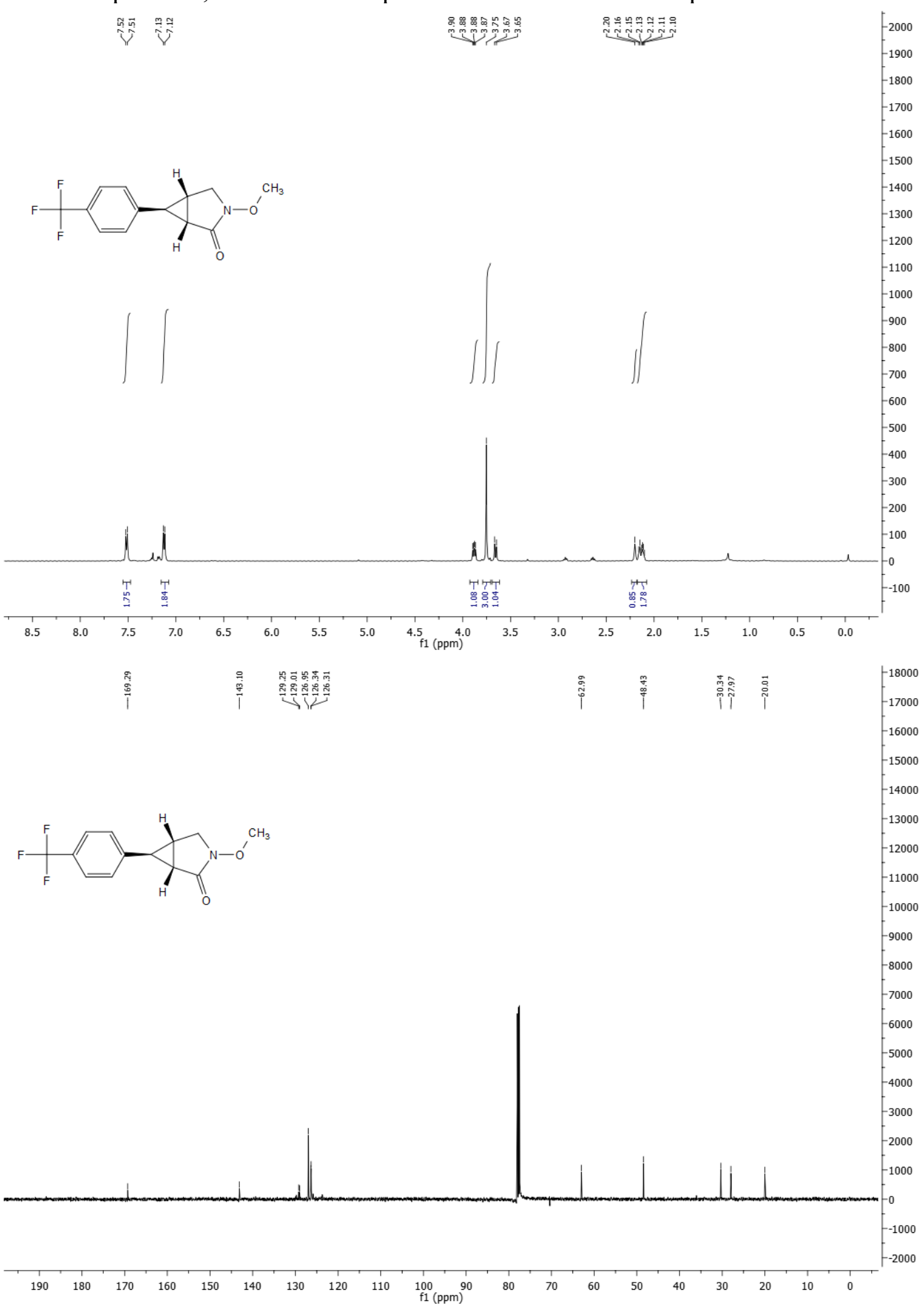


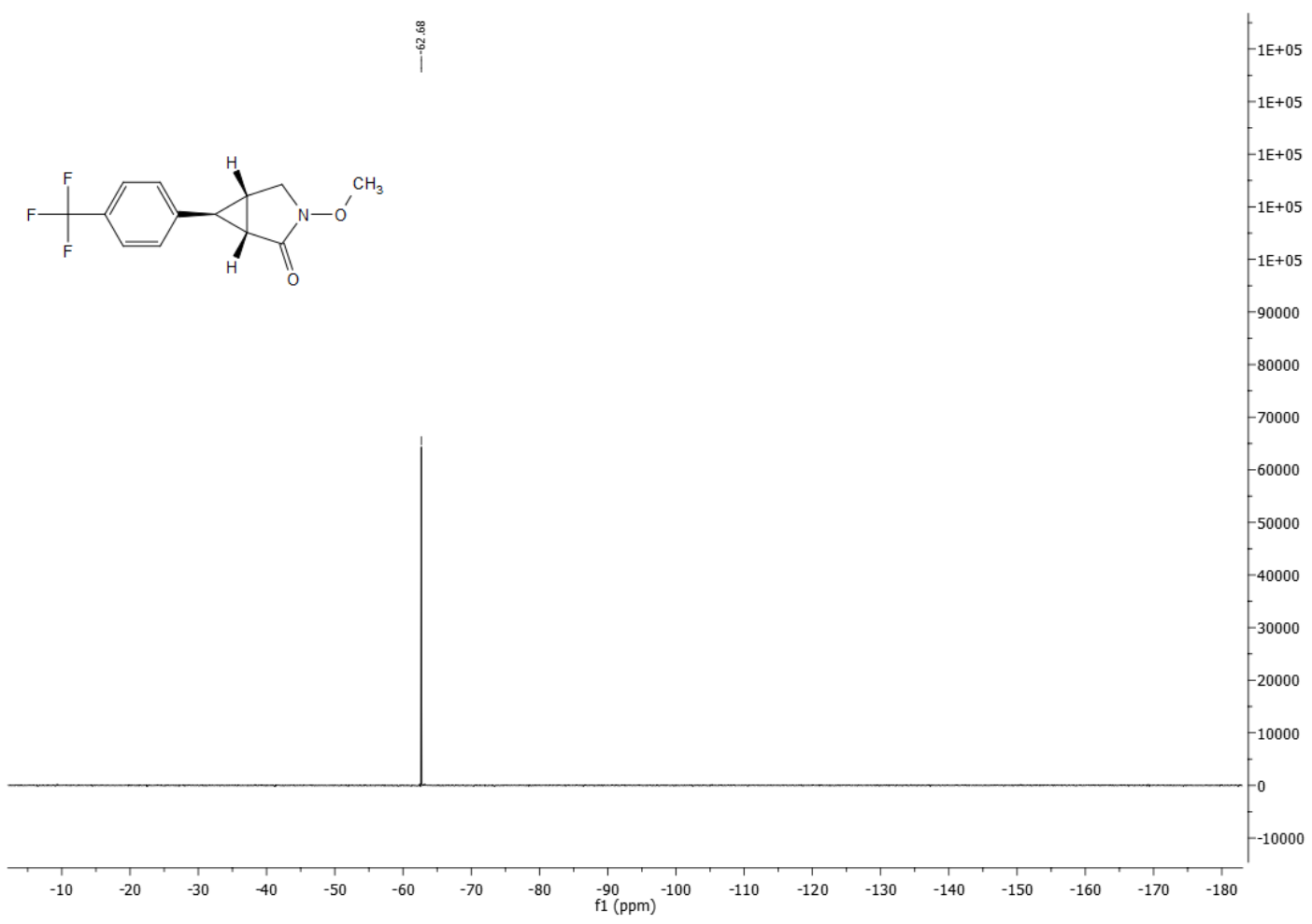


(1R,5S,6S)-3-methoxy-6-(3-methoxyphenyl)-3-azabicyclo[3.1.0]hexan-2-one (2m): $500 \mathrm{MHz}{ }^{1} \mathrm{H}$ spectrum and $126 \mathrm{MHz}{ }^{13} \mathrm{C}$ spectrum in $\mathrm{CDCl}_{3}$ solvent

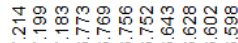

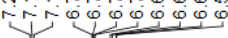

| III<smiles>[2H][C@H]1CN(OC)C[C@H]1c1cccc(OC)c1</smiles>

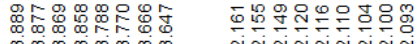

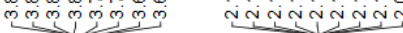

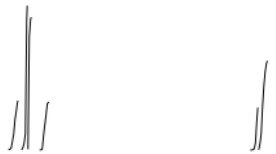

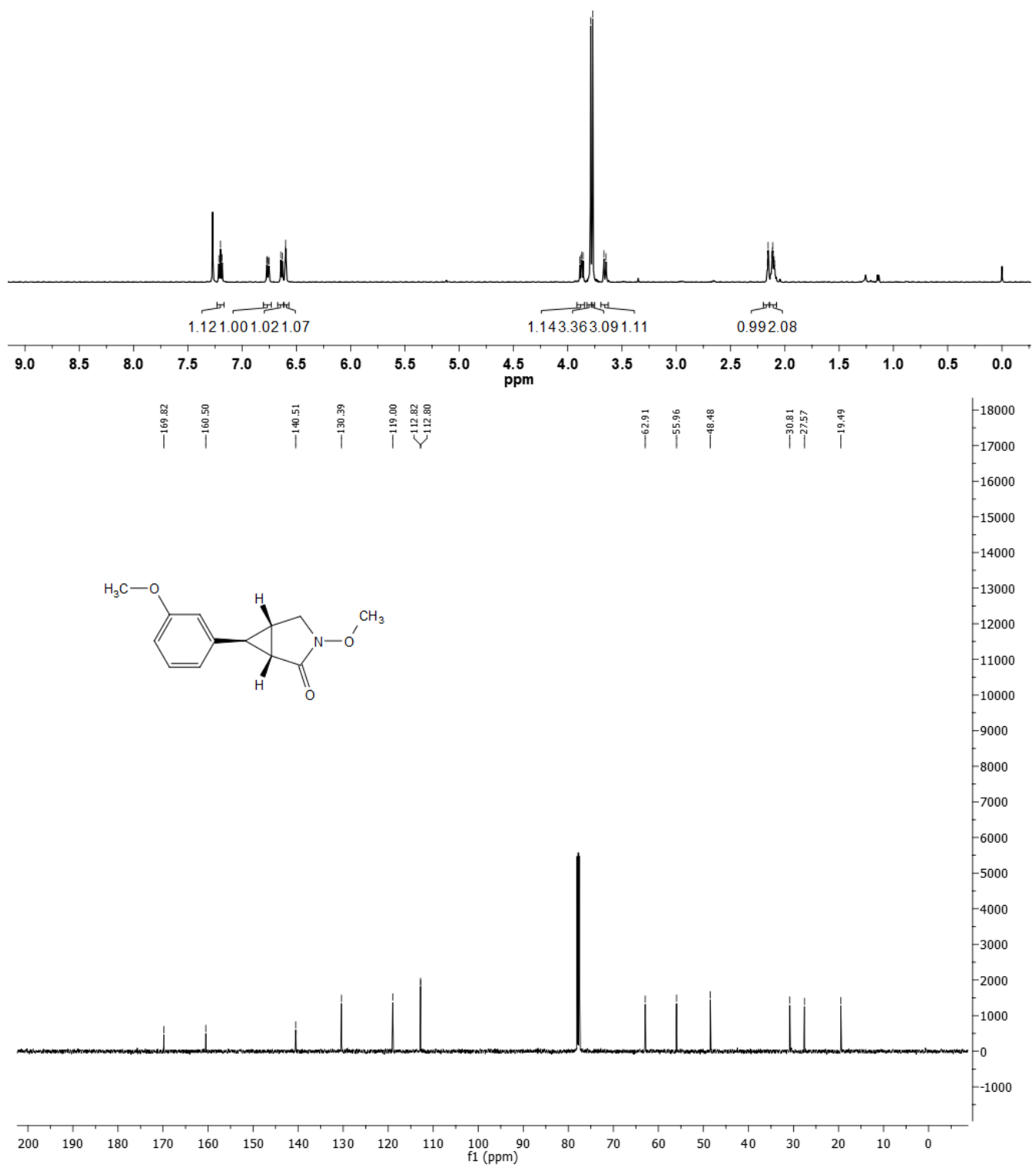


(1R,5S,6S)-3-methoxy-6-(0-tolyl)-3-azabicyclo[3.1.0]hexan-2-one (2n): $500 \mathrm{MHz}{ }^{1} \mathrm{H}$ spectrum and $126 \mathrm{MHz}{ }^{13} \mathrm{C}$ spectrum in $\mathrm{CDCl}_{3}$ solvent

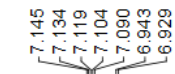

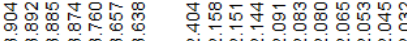

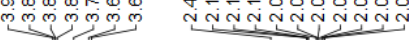
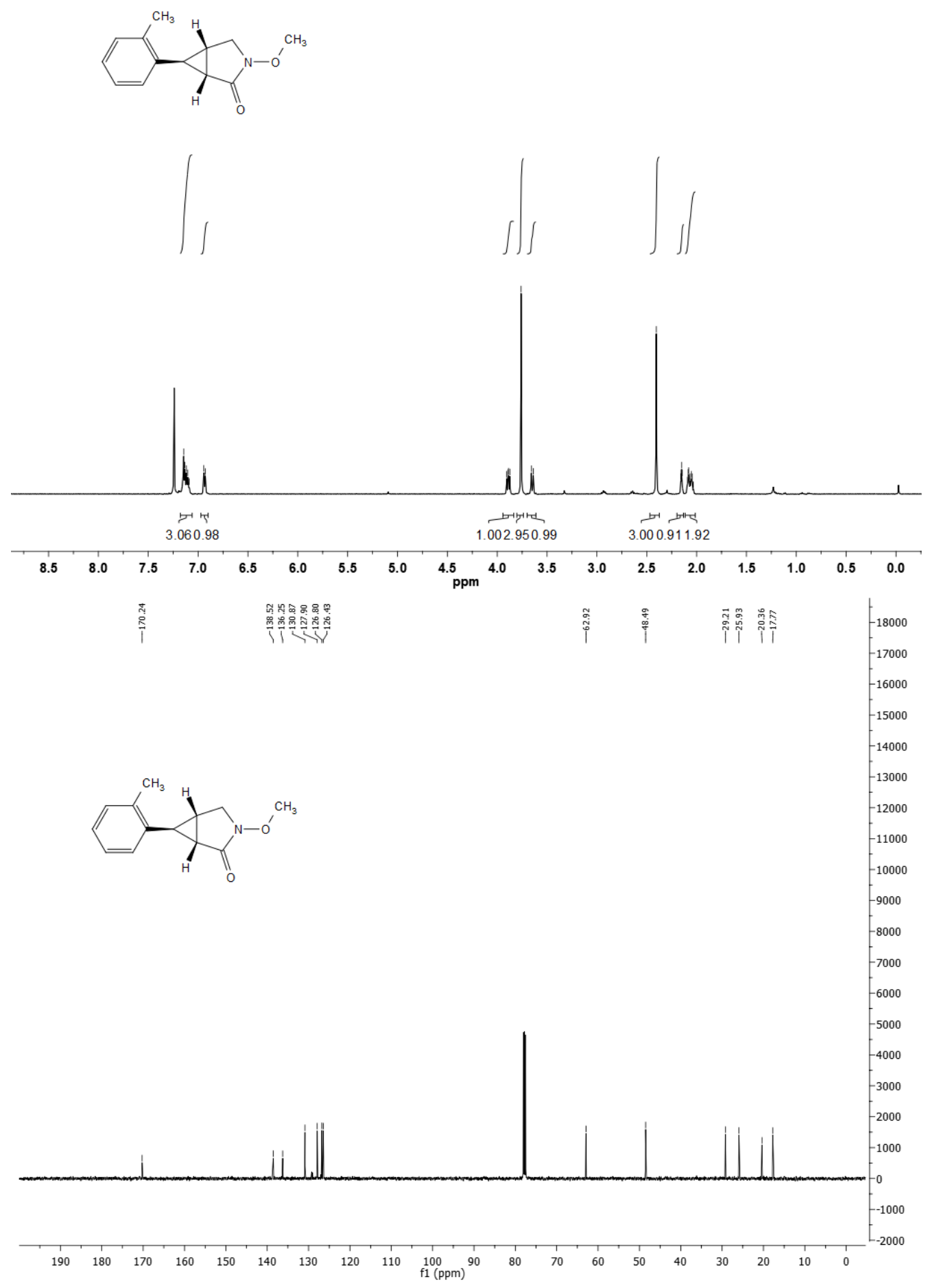
((1R,2S,3S)-2-((methoxyamino)methyl)-3-phenylcyclopropyl)(phenyl)methanone (3): $500 \mathrm{MHz}{ }^{1} \mathrm{H}$ spectrum and $126 \mathrm{MHz}^{13} \mathrm{C}$ spectrum in $\mathrm{CDCl}_{3}$ solvent
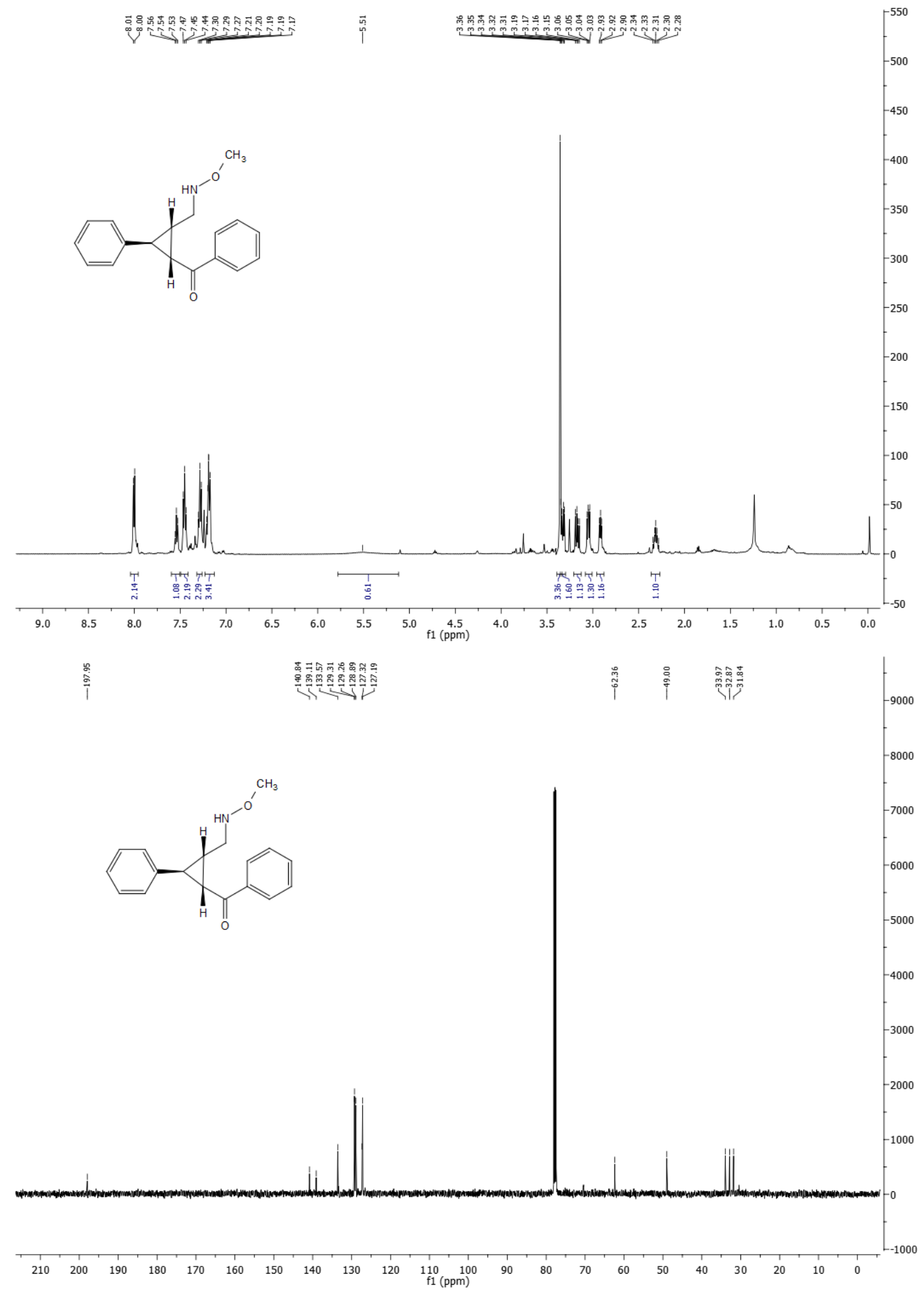
(1R,5S,6S)-3-ethyl-6-phenyl-3-azabicyclo[3.1.0]hexane (4):

$500 \mathrm{MHz}{ }^{1} \mathrm{H}$ spectrum and $126 \mathrm{MHz}{ }^{13} \mathrm{C}$ spectrum in $\mathrm{CDCl}_{3}$ solvent

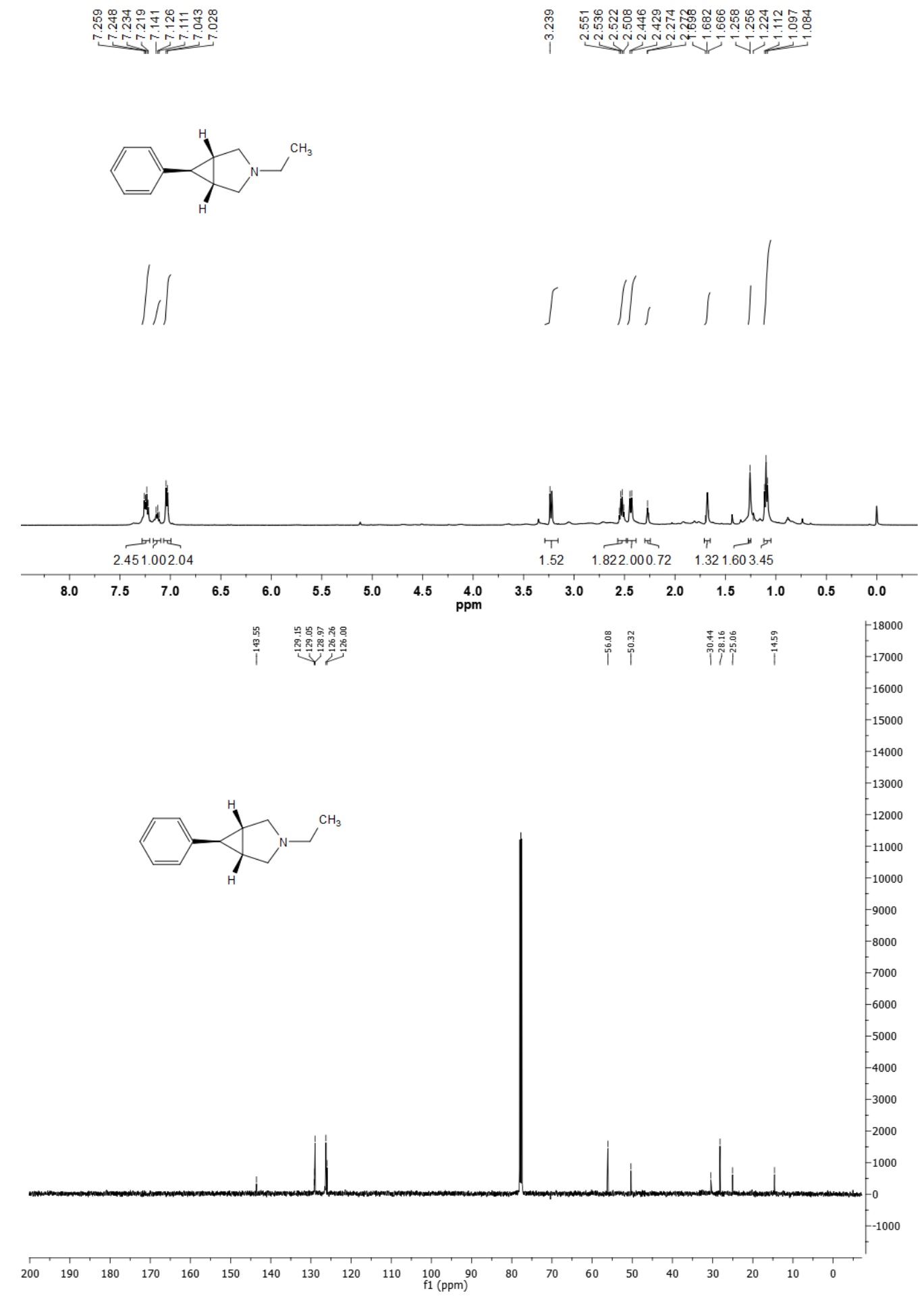

